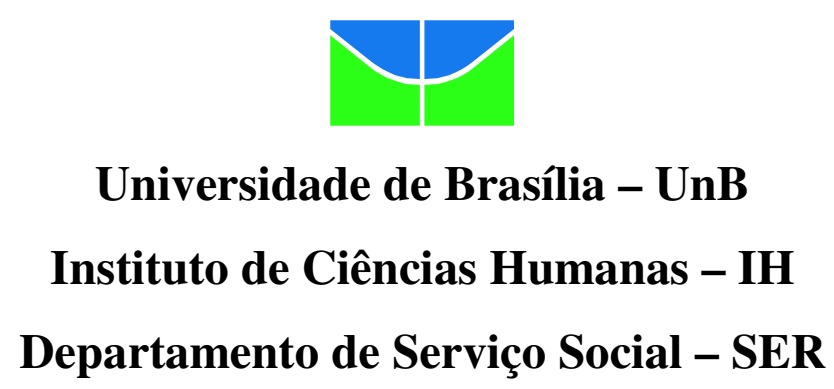

EDUARDO AUGUSTO RODRIGUES BARROS

\title{
O PERFIL INFORMACIONAL DA REDE DE CONSELHEIROS MUNICIPAIS DE ASSISTÊNCIA SOCIAL: CONTRADIÇÕES NA IMPLANTAÇÃO DA REDE SUAS.
}

\begin{abstract}
Monografia apresentada como Trabalho de Conclusão de Curso ao Departamento de Serviço Social do Instituto de Ciências Humanas da Universidade de Brasília - UnB, como requisito parcial à obtenção do título de Bacharel em Serviço Social.

Orientador: Prof. Dr. Perci Coelho de Souza
\end{abstract}

Brasília 
EDUARDO AUGUSTO RODRIGUES BARROS

O PERFIL INFORMACIONAL DA REDE DE CONSELHEIROS MUNICIPAIS DE ASSISTÊNCIA SOCIAL: CONTRADIÇÕES NA IMPLANTAÇÃO DA REDE SUAS. 
BARROS, Eduardo A. R.

O Perfil Informacional da rede de conselheiros municipais de Assistência Social: contradições na implantação da Rede SUAS / Eduardo A. R. Barros Brasília, 2009.

$93 \mathrm{p}$.

Trabalho de Conclusão de Curso (Graduação) - Serviço Social, Universidade de Brasília - UnB.

1. Assistência Social; Conselhos municipais; Rede SUAS 
Este Trabalho de Conclusão de Curso foi examinado pela seguinte banca:

\author{
Professor Doutor Perci Coelho de Souza \\ Presidente da banca \\ Universidade de Brasília \\ Instituto de Ciências Humanas - Departamento de Serviço Social
}

\author{
Professora Dra. Maria de Fátima Ramos Brandão \\ Co-orientadora \\ Universidade de Brasília \\ Instituto de Ciências Exatas - Departamento de Ciência da Computação
}

\author{
$\overline{\text { Professora Mestre Ailta Barros }}$ \\ Universidade de Brasília \\ Instituto de Ciências Humanas - Departamento de Serviço Social
}

Assistente Social Quezia Arcoverde Medeiros

Ministério do Desenvolvimento Social e Combate à Fome

Departamento de Gestão do Sistema Único de Assistência Social 
"Quanto mais ingrato for o trabalho maior deve ser a tensão da vontade para realizá-lo'”.

Jean Lojkine 


\section{Agradecimentos}

À Deus por ter me segurado com mão forte nos momentos mais difíceis, fornecendo o apoio mais que necessário para o êxito na caminhada percorrida. Aos meus pais, irmãos, familiares e amigos que nunca deixaram de me incentivar e acreditar em mim.

Ao meu orientador professor Dr. Perci C. Souza que com paciência e companheirismo deu direção ao trabalho desenvolvido, contribuindo, assim, valiosamente para os resultados obtidos. Ao grupo de pesquisa sobre Poder Local, Políticas Urbanas, e Serviço Social LOCUSS UnB, cuja experiência na prática de pesquisa na sublinha Redes Informacionais, coordenada pela professora Dra. Maria de Fátima R. Brandão, enriqueceu meus conhecimentos sobre o impacto das Novas Tecnologias de Informação e Comunicação na sociedades atual.

Ao grupo de pesquisa e extensão Quintas Urbanas da UnB, onde os assuntos da comunidade são tratados no âmbito acadêmico trazendo visibilidade às questões de seu interesse.

Ao meu supervisor de Estágio Supervisionado I e II em Serviço Social, assistente social José Ferreira da Crus, coordenador geral do DGSUAS (Departamento de Gestão do Sistema Único de Assistência Social) que foi o principal incentivador, condutor e facilitador do encaminhamento dessa pesquisa junto ao MDS (Ministério do Desenvolvimento e Combate à Fome) possibilitando a concretização desse trabalho.

À assistente social Quezia Arcoverde pelas informações e conhecimentos precisos aportados como subsídios ao tema estudado. E por fim à equipe do DGSUAS, em especial à CGRGI (Coordenação Geral de Regulação de Gestão Intergovernamental) que no meu período de estágio me proporcionou experiências de grande aprendizagem.

Aos 42 conselheiros que responderam em tempo hábil o questionário da pesquisa Survey para a concretização desse trabalho. 
Universidade de Brasília - UnB

Departamento de Serviço Social - SER

Resumo

O Perfil Informacional da rede de conselheiros municipais de Assistência

Social: contradições na implantação da Rede SUAS.

Por Eduardo A. R. Barros.

Este trabalho é constituído pela associação de três grandes eixos, sendo eles: a composição histórica da Assistência Social no contexto das políticas sociais do Estado de Bem Estar Social, até a contemporaneidade do Sistema Único de Assistência Social (SUAS); a inserção e institucionalização do controle social (democrático), por meio dos conselhos gestores, na gestão das políticas sociais, onde o conselho municipal, estadual e federal se torna Lócus primordial de construção e consolidação de uma concepção de gestão pública, democrática e participativa; por último toma-se esses eixos dentro da conjuntura da Revolução Informacional, destacando as potencialidades da Rede SUAS para a gestão e o controle democrático da política pública de Assistência Social.

A construção e associação desses eixos juntamente com a pesquisa de campo junto aos conselheiros municipais procura desvelar o perfil informacional da rede de conselheiros municipais de Assistência Social: as contradições na implantação da Rede SUAS.

Palavras - chave: Assistência Social; Conselhos municipais; Rede SUAS. 


\section{Lista de Siglas}

CAP - Caixa de Aposentadoria de Pensão

CEAS - Conselho Estadual de Assistência Social

CGRGI - Coordenação de Geral de Regulação de Gestão Intergovernamental

CMAS - Conselho Municipal de Assistência Social

CNAS - Conselho Nacional de Assistência Social

CRAS - Centro de Referência de Assistência Social

CREAS - Centro de Referência Especializado de Assistência Social

DGSUAS - Departamento de Gestão do Sistema Único de Assistência Social

FEAS - Fundo Estadual de Assistência Social

FLBA - Fundação Legionária Brasileira de Assistência

FMAS - Fundo Municipal de Assistência Social

FNAS - Fundo Nacional de Assistência Social

LBA - Legião Brasileira de Assistência

LOAS - Lei Orgânica de Assistência Social

MDS - Ministério do Desenvolvimento Social e Combate à Fome

NOB/SUAS - Norma Operacional Básica do Sistema Único de Assistência Social

NTIC - Novas Tecnologias de Informação e Comunicação

PAIF - Programa de Atenção Integral à Família

PETI - Programa de Erradicação ao Trabalho Infantil

PNAS - Política Nacional de Assistência Social

SNAS - Secretaria Nacional de Assistência Social

SINPAS - Sistema Nacional de Previdência Social

SUAS - Sistema Único de Assistência Social

SUS - Sistema Único de Saúde

TCU - Tribunal de Contas da União 


\section{Sumário}

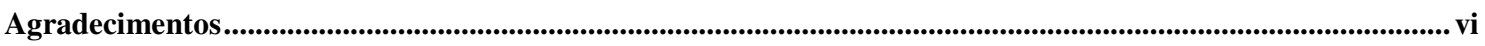

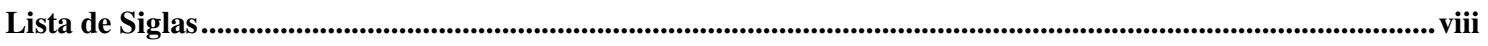

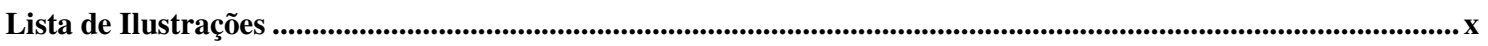

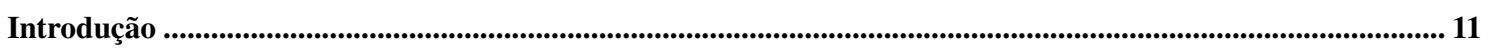

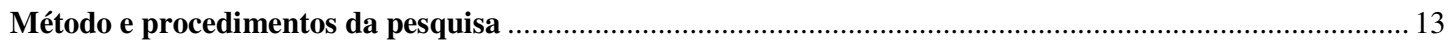

Capítulo 1-A Assistência Social no contexto das Políticas Sociais....................................................................20

1.1 As Políticas Sociais do Estado de Bem Estar Social...........................................................................2 20

1.2 Trajetória da Política de Assistência Social no Brasil de 1930 ao século XXI ..........................................28

1.3 O SUAS estabelecendo uma nova concepção de Assistência Social: ........................................................... 37

Capítulo 2 - Os Conselhos de Assistência Social como um espaço público e democrático para direção e gestão

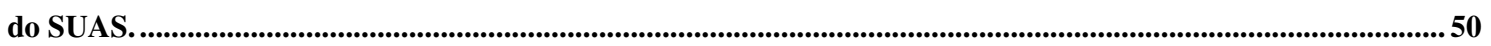

2.1 A participação como um ponto central dos conselhos gestores. ........................................................... 50

2.2 Os conselhos municipais de Assistência Social como esfera pública. ........................................................55

2.3 Os conselhos municipais como controle democrático um eixo constitutivo da PNAS. ............................59

Capítulo 3 - As Novas Tecnologias de Informação e Comunicação como um advento para o exercício dos

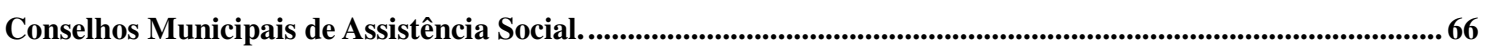

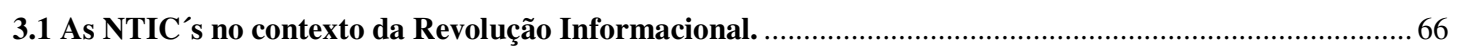

3.2 Rede SUAS: a produção, unificação, armazenamento e circulação da informação estratégica como uma nova forma de gestão descentralizada e participativa............................................................................... 71

3.3 A contribuição da Rede SUAS para eficiência dos conselheiros municipais nas suas atribuições.............76

Capítulo 4 - O Perfil informacional dos Conselheiros Municipais de Assistência Social: contradições na

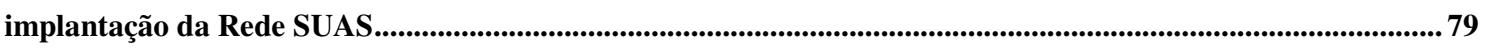

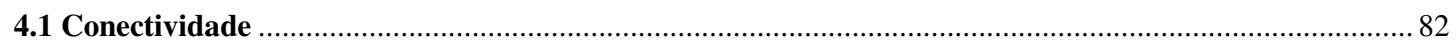

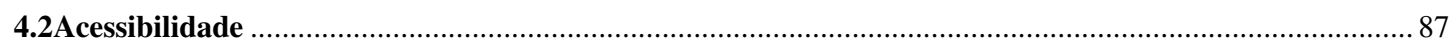

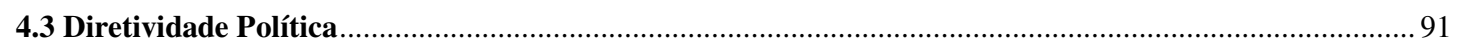

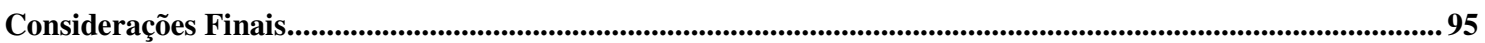

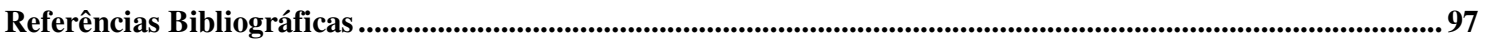

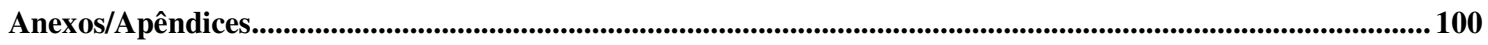




\section{Lista de Ilustrações}

Gráfico 1 Porcentagem do $\mathrm{n}^{\circ}$ de respondentes em relação ao total da amostra .............. 17

Gráfico 3- Grau de conectividade presencial entre a base e o conselheiro off-line ....... 82

Gráfico 4- Grau de conectividade on line entre a base, conselheiro da secretaria executiva do CMAS, CNAS

Gráfico 5- Grau de conectividade dos conselheiros da secretaria executiva do CMAS à

Rede SUAS

Gráfico 6- Grau de relevância dada ao SUASWEB para tomada de decisão dos conselheiros

Gráfico 7- Grau de acessibilidade para a processualidade e conformação do enlace comissões temáticas e conselhos.

Gráfico 8- Grau de acessibilidade relacionada ao fluxo de informações do circuito CEAS/conselheiros CMAS

Gráfico 9- Grau de acessibilidade participativa dos conselheiros nas atividades virtuais extras proporcionadas pelo MDS

Gráfico 10- Grau de acessibilidade tipo audiência à Rede SUAS para monitoramento dos Fundos

Gráfico 11- Orientação de direção do vetor informacional que conforma a atitude informacional dos conselheiros.

Gráfico 12- Orientação do vetor direcional para fiscalização da mesa diretora do conselho.

Gráfico 13- Orientação do vetor direcional relacionada à intensidade da atitude para consulta da Rede SUAS pelos conselheiros do CMAS antes das conferências.

Gráfico 14- Orientação do vetor direcional relacionada à intensidade da atitude informacional Geo-referenciada do conselheiro de modo que ele influencie as decisões do conselho 


\section{Introdução}

A gestão das políticas sociais configurada no formato descentralizado e democrático, onde os municípios e estados ganham responsabilidades, competências e autonomia correspondentes à sua esfera de governo, abertas à participação popular, com direção única da estância federal, permite uma nova modalidade de gestão com direito ao controle social e público da sociedade civil às ações do Estado.

Esse processo histórico e estrutural visto na ótica de uma sociedade capitalista ganha contornos cada vez maiores na sociedade brasileira. Portanto, exige-se que seja observado, também, no contexto das mutações sociotécnicas que tem origem no mundo do trabalho, por meio da inserção das Novas Tecnologias de Informação e Comunicação (NTICs) ${ }^{1}$, que altera o modelo de produção e reprodução da sociedade, vistas no espectro da "Revolução Informacional". Nesse sentido, as redes informacionais são engendradas, onde circulam e se produzem conhecimentos e informações cada vez mais complexas abrangendo todos os setores da sociedade inclusive, aqueles referentes às Políticas Sociais.

Os novos elementos de gestão da política pública, como é o caso da Política Nacional de Assistência Social (PNAS) ${ }^{2}$, são resultados de intensas lutas e embates da sociedade civil organizada, dos movimentos sociais. Desse ponto de vista tais elementos são apreendidos e legitimados pela Carta magna da nação. Ao mesmo tempo podem e devem ser vistos no contexto da Revolução Informacional e das Redes Informacionais, institucionalizando, assim, uma nova cultura de implementação e gestão das políticas sociais como: a saúde, a educação, a assistência e previdência social, todas, subordinadas ao interesse público, social, participativo e democrático.

Deste modo, surge um desafio para as instituições implementadoras das políticas sociais, as entidades e atores (as) envolvidos (as), que é o de colocar em prática e fazer funcionar essa nova dinâmica em rede da gestão pública, participativa e democrática. Portanto, mais do que ganhos tecnológicos o desafio é ampliar os direitos sociais para aqueles que se utilizam dos serviços, programas, projetos e benefícios dessas políticas. Entretanto a institucionalização dessa nova cultura na lógica descentralizada, em rede,

\footnotetext{
${ }^{1}$ De agora em diante utilizarei NTICs quando me referir as Novas Tecnologias de Informação e Comunicação.

${ }^{2}$ A partir de agora ao se remeter à Política Nacional de Assistência Social, utilizarei PNAS
} 
onde os municípios ganham mais autonomia e responsabilidades requererá por parte do Estado, da sociedade civil, dos movimentos sociais, maior engajamento e protagonismo para que as políticas sociais se realizem nos moldes de uma revolução social com o imperativo das redes digitalizadas.

Do ponto de vista histórico, essas políticas se deram de forma autoritária, tecnocrática, secretamente e pautadas na visão liberal e do direito privado, onde as políticas sociais sempre foram vistas e colocadas como secundárias e até mesmo substitutivas e nunca como primordiais e essenciais.

A Assistência Social construída, no Brasil, de forma conservadora no âmbito do privado, da benevolência, caridade, ajuda, favor, paternalismo, apadrinhamento, clientelismo ${ }^{3}$ e nunca, até o SUAS, como direito e proteção social contra as agruras que o modo capitalista de produção e as "vicissitudes" da vida produzem.

Assim tomando-se a perspectiva da Assistência Social como uma política pública de proteção social de direito, tendo como fundamento e principio uma nova modalidade de gestão, isto é, uma gestão que seja efetivamente descentralizada e participativa com controle social, por meio dos conselheiros dos conselhos municipais de Assistência Social.

Neste sentido pretende-se responder na perspectiva teórica da Escola Marxista Francesa $^{4}$ qual é o Perfil Informacional da Rede de Conselheiros Municipais de Assistência Social brasileira no uso das NTICs considerando-se, de um lado, as contradições ético-políticas e técnico-operacionais dos conselheiros e de outro as trocas informacionais desses conselheiros do ponto de vista da eficácia do eixo controle social da PNAS?

A hipótese é que existem contradições de ordem ético-políticas e técnicooperacionais no processo de migração das trocas informacionais desses sujeitos para os Sistemas de Informações digitalizados que orientam a eficácia do eixo controle social da PNAS.

\footnotetext{
${ }^{3}$ Esses conceitos típicos da tradição conservadora da Assistência Social serão detalhados baseados em Sposati \& Falcão (1989) no capítulo 1deste trabalho e no que diz respeito à distinção entre o privado e público no capítulo 2 .

${ }^{4}$ Apoiando-se no quadro referencial do materialismo histórico, a Escola Marxista Francesa foi fundada por Henri Lefebvre. Nesta Escola surgiram os primeiros estudos de Manuel Castells, Jean Lojkine entre outros. Neste trabalho me detenho à Lojkine e Castells.
} 
No primeiro capítulo procura-se contextualizar a política social do Estado capitalista de Bem Estar Social, juntamente com a trajetória da assistência social como uma política desse Estado, admitindo os avanços inéditos do SUAS.

No segundo capítulo articula-se as categorias participação e esfera pública no que toca o paradigma do controle social da PNAS nas atribuições e competências dos conselheiros para as novas necessidades de gestão dessa política pública.

O terceiro capítulo contempla o quadro referencial teórico da Revolução Informacional destacando as potencialidades da Rede SUAS que está sendo projetada no molde democrático, descentralizado e participativo. Ainda nesse capítulo identifico quais são as categorias úteis para o estudo das NTICs, tendo em vista a análise da eficácia e eficiência informacional das atribuições e competências dos conselheiros para a gestão do SUAS.

O quarto capítulo é composto pelos resultados da pesquisa de campo baseada na aplicação das macro-categorias das redes informacionais, quais seja a conectividade, acessibilidade e diretividade política e das subcategorias enlaces, circuitos e fluxos das informações trocadas pela a amostra de conselheiros municipais.

Assim, esse trabalho visa destacar as contradições na implantação das NTICs aplicada à Rede SUAS na perspectiva dos conselheiros municipais de Assistência Social dos municípios habilitados na gestão plena.

\section{Método e procedimentos da pesquisa}

Considerei nessa pesquisa o método dialético para a interpretação do fenômeno das redes informacionais realizada pelos (as) conselheiros (as) municipais no âmbito da Política da Assistência Social brasileira. Pois, em concordância com Demo (1995) admite-se que o método dialético é aquele que se ocupa da apreensão da realidade social em movimento, posto que são sempre históricas as relações sociais que nela estão imbricadas.

Nessa perspectiva, a realidade social é vista como possuidora de condições subjetivas e objetivas, essas condições se interagem dialeticamente influenciando ou modificando uma a outra. Segundo Demo (1995), existem diversas dialéticas sendo que, umas até se divergem entre si. Meu ponto de partida metodológico inclinou-se em favor do modelo definido pelo autor como sendo o histórico-estrutural. 
O método dialético histórico-estrutural possui como base o conceito de totalidade, onde três conceitos serão os alicerces para sua existência. Estes conceitos são: a tese, a antítese e a síntese, sendo que a última será o resultado do confronto entre as duas primeiras.

No estudo que segue a tese é a formação social historicamente contextualizada, a antítese se apresenta como o movimento de superação desse momento para que dessa contradição se explicite uma síntese. Assim procurei capturar como tese, de um lado as relações sociais típicas da sociedade capitalista contemporânea, e, de outro, os limites impostos a essas relações históricas (dimensão política), segundo a lógica da acumulação do capital (dimensão relativa à produção/reprodução material da sociedade).

A pesquisa combinou dois procedimentos de coleta de dados quantitativo e qualitativo que se combinaram na síntese dos resultados finais. $O$ primeiro procedimento foi a coleta de dados junto aos conselheiros mediante a aplicação de um instrumento de pesquisa tipo Survey (questionário via Internet), enviado pelo correio eletrônico institucional do Ministério do Desenvolvimento Social e Combate à Fome (MDS) para os conselhos municipais. O segundo foi caracterizado como uma pesquisa documental de textos que orientam a Política Nacional de Assistência Social - PNAS e o Sistema Único de Assistência Social (SUAS).

\section{Sobre os procedimentos da pesquisa Survey}

Admiti nesta pesquisa que a sociedade capitalista contemporânea vem sendo marcadamente atravessada por uma Revolução Informacional (Lojkine, 1995) que se coloca como um processo de largo espectro de transformações, sobretudo, de caráter sociotécnico. Segundo o autor, para além das aparências da mudança tecnológica materializada pela introdução dos computadores no cotidiano das pessoas, essa perspectiva teórica nos remete ao desafio de tentar entender uma nova sociabilidade sob

o impacto dos novos imperativos das Redes Sociais Informacionais. Ou seja, a preponderância da nova dinâmica das redes baseadas em sistemas digitalizados de informação (Souza, 2008).

Dentro dessa perspectiva dialética histórico-estrutural aplicamos procedimentos de apreensão dessas dinâmicas segundo três macro-categorias para análise de redes 
informacionais propostas por Souza (2005), são elas: Conectividade, acessibilidade e diretividade política.

Do ponto de vista da conectividade, a pesquisa se orientou para explicitar a composição orgânica das Redes Sociais Informacionais, isto é, da identificação quantitativa e qualitativa dos "nós" que compõem uma arquitetura social que se configura como uma dinâmica de rede social informacional. Nesse âmbito, coube à pesquisa identificar, descrever e caracterizar um conjunto de Conselheiros como "nós" de uma rede informacional considerados em suas relações políticas inscritos na Política Nacional de Assistência Social.

A acessibilidade conduziu a pesquisa à análise do grau de eficácia e eficiência das trocas informacionais entre os "nós" (atores) que compõem a rede informacional dos conselheiros municipais de Assistência Social brasileira. Essa macro-categoria foi aplicada ao objeto de modo a caracterizar e explicitar os limites e potencialidades das trocas informacionais entre os nós da rede estudada. Para tanto foi necessário estudar os enlaces, os circuitos e fluxos informacionais produzidas pela amostra dos conselheiros enredados. Desse modo, a acessibilidade foi aplicada à rede socioinformacional estudada procurando explicitar as contradições existentes entre meios e fins dessas trocas segundo a pesquisa paralela que fiz sobre os documentos da PNAS e Rede SUAS que tratarei mais adiante.

Para a aplicação da macro-categoria da diretividade política considerou-se a dinâmica dos enlaces, circuitos e fluxos informacionais segundo a análise dos diferentes sentidos políticos em disputa na rede. Isto é, procurei evidenciar as principais tendências informacionais em disputa considerando-se, de um lado, as posturas políticoinformacionais de caráter conservador, ou seja, associáveis às tendências políticas pautadas: na privatização, no clientelismo, paternalismo, assistencialismo, caridade, autoritarismo, em contraposição hegemônica às posturas político-informacionais associáveis às tendências políticas pautadas nos princípios de: publicização, democratização, participação, no direito e emancipação dos usuários e atores sociais envolvidos, tendo em vista uma leitura crítica da competência desses conselheiros inseridos na Política Nacional de Assistência Social.

A aplicação dessa matriz categorial para análise dos dados de minha pesquisa pode ser assim sistematizada esquematicamente conforme o quadro abaixo. 


Enlace - relação
informacional entre
no mínimo dois nós
da rede
Circuitos -
relação
informacional
sistemática entre no
mínimo dois nós da
rede
Fluxos - Volume
informacional
sistemático entre no
mínimo dois nós da
rede.

Conectividade

Composição orgânica da

Rede

Descrição e caracterização dos enlaces da amostra da rede

\section{Descrição e} caracterização dos circuitos da amostra da rede

Descrição e
caracterização dos
fluxos da amostra da
rede

\author{
Acessibilidade \\ Eficácia /eficiência das trocas de \\ informações
}

Descrição e caracterização da relação eficácia/eficiência dos enlaces da amostra da rede no tocante às metas do Plano Decenal da PNAS, LOAS e NOB/SUAS E RESOLUÇÕES DO CNAS

Descrição e caracterização da
relação eficácia/eficiência dos
circuitos da amostra da rede no
tocante às metas do Plano
Decenal da PNAS, LOAS e
NOB/SUAS E RESOLUÇÕES
DO CNAS

Descrição e caracterização da relação eficácia/eficiência dos fluxos da amostra da rede no tocante às metas do Plano Decenal da PNAS, LOAS e NOB/SUAS E RESOLUÇÕES DO CNAS
Diretividade Política

Vetorialização - sentido político hegemônico da rede

Descrição e caracterização da vetorialização das trocas de informacionais dos enlaces da amostra da rede no tocante à metas do Plano Decenal da PNAS, LOAS e NOB/SUAS E RESOLUÇÕES DO CNAS

Descrição e caracterização da vetorialização das trocas de informacionais dos circuitos da amostra da rede no tocante à metas do Plano Decenal da PNAS, LOAS e NOB/SUAS E RESOLUÇÕES DO CNAS

Descrição e caracterização da vetorialização das trocas de informacionais dos fluxos da amostra da rede no tocante à metas do Plano Decenal da PNAS, LOAS e NOB/SUAS E RESOLUÇÕES DO CNAS

Esta pesquisa é resultado de um processo sucessivo de aproximações ao objeto. A etapa exploratória se iniciou no período de estágio supervisionado que tratarei mais adiante. A etapa da pesquisa Survey foi realizada mediante um demorado processo de articulação inter institucional LOCUSS-UnB, MDS para elaboração dos questionários e envio desses aos conselhos municipais via correio eletrônico por mala direta do MDS.

Os correios eletrônicos foram mandados com um texto explicativo e de recomendação da instituição para o preenchimento e re-envio dos referidos questionários no primeiro prazo de 28 dias correspondente ao dia 13/07/09, dia do envio, ao dia 31/07/09, e no segundo prazo prorrogado por 5 dias, pela falta de respostas dos conselheiros, foram enviados novamente no dia 29/07, novos e-mails para os conselhos reiterando que os conselheiros preenchessem e reenviassem o questionário preenchido até o dia 5/08.

O texto explicativo e de recomendação predizia que apenas um (a) conselheiro (a) que integra a secretaria executiva, escolhido por sorteio, responderia e reenviaria novamente ao pesquisador no endereço eletrônico: duarquivos84@gmail.com. Foi escolhida a secretaria executiva, pois ela representa uma peça chave para o bom 
andamento dos conselhos, pois a ela cabe repassar informações referentes às pautas, dias das reuniões, prazos para entrega dos trabalhos dos conselhos; publicar no diário oficial as resoluções dos respectivos conselhos, assim como repassá-las quando necessário, juntamente com os registros e atas produzidas por estes.

A pesquisa teve como amostra 383 conselheiros dos municípios habilitados na Gestão Plena ${ }^{5}$ da Assistência Social no universo, em média, de 55.630 conselheiros. Foi escolhido os conselheiros dos municípios habilitados em gestão plena, pois nessa qualidade de gestão, o município deve ter o conselho funcionando em plenas condições como previsto na NOB-SUAS.

Gráfico 1 Porcentagem do ${ }^{\circ}$ de respondentes em relação ao total da amostra

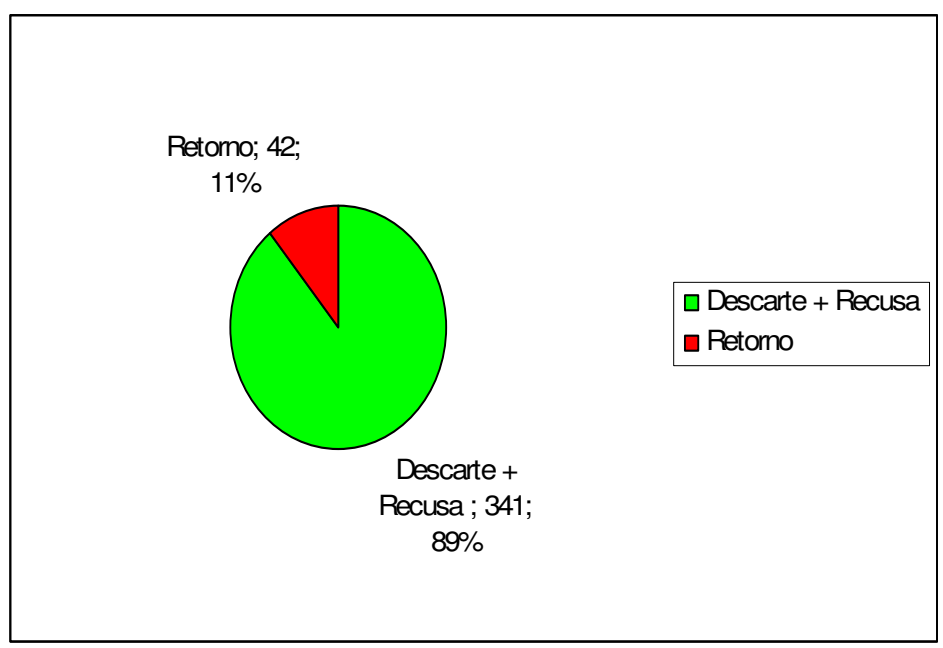

Total: 383

\section{Pesquisa Documental}

O método da pesquisa documental se consistiu na análise de legislações como a LOAS que define os parâmetros para atuação dos conselhos municipais na nova lógica de gestão descentralizada e participativa. A PNAS que organiza e coloca em prática as orientações e diretrizes no campo socioassistencial de proteção social. A NOB SUAS que operacionaliza os serviços, programas, projetos e benefícios da Assistência Social em torno de um sistema único e integrado. Ainda foi observado as metas do Plano Decenal da Assistência Social, relativos ao controle social, a democratização e a

5 Total e porcentagem de municípios habilitados em gestão inicial, básica, e plena por Estado em 2009, segundo a Norma Operacional Básica do SUAS/2005. Comissão Intergestores Bipartite. 
participação, e por último a resolução CNAS n 237 de 2006, da que define as diretrizes para a estruturação, reformulação e funcionamento dos Conselhos de Assistência Social.

\section{Antecedentes da pesquisa}

A etapa de aproximação ao objeto da presente pesquisa foi realizada ao longo do período de execução do estágio supervisionado I e II em Serviço Social, realizado na SNAS (Secretária Nacional de Assistência Social), onde está localizado o DGSUAS (Departamento de Gestão do Sistema Único de Assistência Social).

O supervisor de campo, foi o assistente social José Ferreira da Crus que é assessor dessa secretaria. Eu contei, também, na Coordenação Geral Regulação Gestão Intergovernamental (CGRGI), com orientações da assistente social Alessandra Gadiole. O período do estágio supervisionado I e II foi o segundo semestre de 2007 até o fim do primeiro semestre de 2008. A CGRGI inserida dentro do Departamento de Gestão do SUAS que está no âmbito da SNAS, foi o lócus da experiência de estágio.

Neste espaço tive contato com uma gama de gestores municipais, conselheiros, prestando informações técnicas, por telefone, sobre os aplicativos da Rede $\operatorname{SUAS}^{6}$ mais especificamente o SUASWEB. Alocado na CGRGI fazia, também, senhas para que esses gestores e conselheiros pudessem ter acesso ao sistema.

A senha de gestor e de conselho eram diferenciadas, posto que ao gestor competia preencher o plano de ação do respectivo ano, quando o preenchimento fosse finalizado com todos os elementos que cabia à gestão, ele era enviado ao sistema. Em seguida, na mesma página virtual, aparecia uma aba definida como PARECER, os

\footnotetext{
6 A Rede SUAS que abrange essa nova modalidade de gestão é um sistema de informação que tem como meta responder as novas necessidades de informação e comunicação no âmbito do SUAS.

Os aplicativos que compõem a Rede SUAS são: SUASWeb, GEOSUAS, INFOSUAS, SISCONWeb, SICNASWeb. Os aplicativos que correspondem a gestão financeira são: SISFAF, SIAORC, SISCON.

O Plano de Ação onde é inserido o parecer do conselho está no âmbito do SUASWEB. Este sistema tem como finalidade atender o novo modelo de gestão descentralizado e participativo com controle social. Além do Plano de Ação o SUASWEB abarca o Demonstrativo Sintético Financeiro e informações essenciais para gestores como saldos, contas correntes, beneficiários do BPC (Beneficio de Prestação Continuada), parcelas pagas contendo ordem bancária, data do pagamento entre outros. (www.mds.gov.br acesso em 09/04/09).
} 
gestores não podiam mais fazer qualquer alteração no plano e muito menos elaborar o parecer sobre o respectivo aprovando ou o rechaçando. Cabia agora aos conselheiros se reunirem, analisarem o referente Plano de Ação observando se o que foi preenchido, realmente, estava de acordo com o plano municipal de assistência social, se os recursos co-financiados estavam sendo bem utilizados, se os serviços subsidiados estavam realmente atendendo as necessidades da população usuária.

Após análise do Plano de Ação pelos conselheiros que deveria ser submetida em reunião, registrado em ata; eles emitiriam um parecer aprovando ou não o Plano de Ação. Este parecer deveria ser digitalizado e enviado por meio do SUASWEB inserido na parte que lhe foi destinada.

Todos os procedimentos, desde o preenchimento do Plano pelos gestores onde ele deveria atualizar todos os dados relativos ao fundo municipal, ao conselho, ao órgão ente gestor, os dados dos Pisos de proteção do SUAS, até o parecer do conselho deveriam obedecer a um prazo pactuado pela CIT. Caso o município não preenchesse e fizesse todos esses procedimentos no prazo pré-definido corria o risco de entrar em processo de desabilitação, onde os recursos federais poderiam ser suspensos ou repassados para a responsabilidade do estado do respectivo município.

Após o estágio supervisionado I e II, obrigatório, dei início ao planejamento e a execução da pesquisa por meio da elaboração de um projeto. Com posse do projeto de pesquisa comecei a fazer as mediações com o MDS e o CNAS para encaminhar a pesquisa proposta. Após todos os trâmites burocráticos, entre a UnB e as instituições referidas, iniciei a pesquisa de campo enviando, via e-mail, o instrumento de pesquisa para os conselhos por meio do MDS. 


\section{Capítulo 1- A Assistência Social no contexto das Políticas Sociais}

\subsection{As Políticas Sociais do Estado de Bem Estar Social}

Neste sub capítulo a política social será abordada nas suas relações com os tipos de Estado, incluindo o capitalista, de Bem Estar Social, pois entende-se que as redes socioinformacionais formadas, hoje, pelas políticas de proteção social perpassa pela relação entre as formas do Estado, mas especificamente o capitalista, em conduzi-las. Neste sentido, a disciplina científica política social será fundamentada a partir das reflexões da professora Potyara Amazoneida P. Pereira (2008), que nos possibilita uma boa compreensão a respeito dessa questão. Ao se falar de política social, é necessário fazer uma leitura sobre as concepções de Estado e as formas que ele relaciona com a sociedade. De acordo com Pereira (2008), esse debate remonta a trajetória histórica que inicia na antiguidade grega. A partir de uma análise da antiga sociedade até a atualidade pode ser destacada três tendências recorrentes que dão base para a discussão de Estado e sociedade. A primeira delas é que o Estado não é igual em todas as fases históricas e contextos sócio-culturais e por isso, ele não pode ser tomado como algo definitivo e universal. Em segundo lugar, o Estado não gera a sociedade e sim esta é quem cria aquele. A última, as doutrinas, teorias e concepções são criadas e discutem o significado, a função e a índole do ente Estatal. Assim, o Ente deve ser tomado como um espaço onde os interesses de grupos, classes, segmentos sociais são colocados em questão, onde o interesse dominante tende a prevalecer sobre o outro, por isso, esse organismo estadista está longe de ser um campo neutro e pacífico desligado do contexto histórico que o engendrou; de acordo com Poulantzas (1981) apud Pereira (2008). O Estado é o resultado da "condensação de relações das forças sociais". Segundo Pereira (2008), a sua existência está condicionada pelos modos produtivos da sociedade de cada época, ou seja, o Estado variou diversas vezes ao longo do tempo seja numa sociedade escravocrata, seja feudal, seja capitalista ou socialista. Assim, esse Organismo tem natureza dinâmica e específica dependendo do contexto histórico no qual se situa, e é 
isso uma condição comum a todos os tipos de Estado é o pacto institucionalizado de dominação a qual vai se exercer o poder.

$\mathrm{Na}$ Grécia antiga, o poder do Estado era limitado pela lei, pois as decisões feitas pelo governo deveriam se submeter às normas estabelecidas, logo deveriam ser respeitadas por todos. Hoje, os Estados Modernos do Ocidente se baseiam nesse modelo grego. O governo heleno tinha uma visão onde as leis eram para atender os anseios da elite da época e não universais atendendo aos anseios de grupos menores.

Na Roma antiga, a noção de Estado teve grande influência da cultura grega e se tornou mais complexa diante da realidade do Império. Os pensadores gregos: Aristóteles e Platão que afirmavam a existência de uma diferença natural entre homens ${ }^{7}$, Roma se baseava também no princípio de igualdade entre eles (homens) ${ }^{8}$, por isso a situação dos escravos, em Roma, era melhor. Nessa condição o Estado romano passou a ser pensado como a "res pública" ou coisa do povo, a questão da justiça foi um avanço na sociedade do Lácio, porquanto independente do modelo de Estado não se podia admitir que ele fosse injusto; a justiça assim se torna no princípio claro e natural de limitação ao poder do Estado.

A idéia, de que o soberano exercia o poder em nome de Deus na idade medieval era um princípio para esta época advinda ainda da antiguidade. Porém a concepção de que somente se poderia exercer esse poder com a aceitação do seu governo pelo povo foi acrescentada, tornando-se um primeiro instrumento de controle público.

O soberano designado por Deus, um pacto entre esse e os súditos, sendo que esse pacto medieval só deveria ser quebrado se um dos dois não cumprisse o direito divino e natural provindo de Deus, que estaria acima do direito do homem, colocando se, assim, como uma forma de defesa da sociedade quanto ao poder do Estado. A partir daí vê-se nesse momento com nitidez o aparecimento do controle público para as ações do Estado concomitantemente com o aparecimento do olhar das ciências sociais e jurídicas a respeito dessa relação Estado e Sociedade.

7 Aristóteles e Platão ao se referirem em desigualdade entre os homens se referem aos homens literalmente, pois na antiga sociedade grega e romana a sociedade era centrada no homem e na figura masculina onde as mulheres não eram consideradas sujeitas e sim extensão dele, é indispensável colocar que nesse tempo existia um consenso de que a mulher pela sua própria condição era por si só inferior. Diferente da sociedade atual onde a mulher conseguiu um avanço para a sua emancipação e eqüidade dos gêneros.

$8 \quad$ Idem. 
Com esse breve contexto sobre o Estado e suas relações dadas na história, cabe ressaltar que as políticas sociais são conseqüências, eminentemente, do clamor da sociedade representada no Estado. Agora ao falar do Estado Capitalista moderno encabeçado pelos "yankees", que para sair da crise na qual se encontravam adotou o Estado de Bem-Estar ou Welfare-State sendo assim um fenômeno característico das sociedades capitalistas do século XX.

As Políticas Sociais do Welfare-State estão intrinsecamente relacionadas ao Estado capitalista, pois a partir dele que elas emergem enquanto medidas de intervenção para regulação social. Elas surgem como uma forma de garantir as próprias condições de existência do sistema capitalista que se encontrava em crise.

A crise do modo de produção capitalista foi resultado do modo de orientação político-econômica liberal aplicada no Estado, que conduzia a produção e os objetivos sociais. Essa orientação liberal está pautada nos valores que se encontram respaldados nos Direitos Individuais.

Os liberais a partir da afirmação e engajamento da filosofia individual se colocavam contra a intervenção do Estado nas liberdades, ditas negativas, que negam a interferência do Estado nos assuntos privados, assim como defendiam, também, a autonomia das instituições de defesa dessas liberdades. Então, o Estado, na concepção liberal, passa a ser entidade separada da sociedade. O que deveria apenas assegurar "os marcos para a atuação conjunta das forças sociais e assegurar a identidade e autonomia dessas" (PEREIRA, Potyara A. P. 2008, p. 29), Configura-se de forma diferente para os liberais os fatores socioeconômicos não afetariam ao Estado, portanto esse não deveria prestar serviços à sociedade para que ela se mantivesse em equilíbrio. Dentro da concepção liberal foi reforçada a questão da igualdade formal e jurídica, porém, ela não assumia compromissos com a desigualdade real e concreta.

A orientação político-econômica liberal aliada à industrialização, sem intromissão do Estado na economia, fomentou a crescente e desenfreada produção. Isso acarretou no excesso de mercadoria, essa sem comprador para tanta oferta ocasionou uma crise no mundo capitalista, onde seu ponto máximo foi a quebra da Bolsa de Valores, em 1929, nos Estados Unidos da América. A crise de produção, somada às crescentes demandas sociais, oriundas da questão social, de acordo com Pereira (2008) fez com que o Estado abandonasse sua postura "eqüidistante" para assumir uma posição interventora. Nesse papel, o organismo Estado passou a regular com vigor a economia e 
a sociedade, assim, como também, passou "a empreender ações sociais, prover benefícios e serviços e exercer atividades empresariais" (PEREIRA, Potyara A. P. 2008, p. 30). A partir desse momento, o próprio sistema capitalista passa a buscar alternativas a manutenção do liberalismo, nascendo desta forma o Estado regulador ou Estado de Bem-Estar (Welfare State). Esse se viu cada vez mais envolvido com a garantia, administração e financiamento do seguro social. É nessa conjuntura que surgem as políticas sociais, como forma de regulação da sociedade para responder as demandas relacionadas à questão social, o que da mesma forma condiciona para o capitalismo sair da crise na qual se encontrava.

Essa modificação em que a entidade Estado se encontrava separado da sociedade altera o padrão para regulador social o que representou uma mudança de paradigma político e jurídico. Essa alteração interferiu na regulação que funcionava livre de obrigações oficiais, assim como ia contra as tradicionais funções do Estado de direito e de seus princípios liberais. A partir desse momento surge uma relação conflituosa entre o Estado de Direito (liberal) e o Estado Social (Welfare State). Nessa relação os direitos individuais ligados às liberdades burguesas, de cunho pessoal, político, econômico passam a coexistir junto dos direitos sociais que estão relacionados à questão da igualdade e à justiça social, isto de acordo com Pereira (2008), e a está vinculado à participação política e a distribuição da riqueza socialmente produzida.

Segundo Pereira (2008), podem ser destacadas três importantes características entre direitos individuais e sociais: o primeiro os direitos individuais são mantenedores à garantia do "status quo", ou paz na ordem jurídica, e estão no âmbito de discussão indivíduo para indivíduo. Os direitos sociais buscam mudanças, já no aspecto da coletividade e são adeptos a elas, a ampliação do seu raio de ação, a especificação e diversificação dos seus titulares e garantias, isso representa uma séria ameaça aos lucros capitalistas. A segunda característica está relacionada ao fato de os direitos individuais não admitem intervenções estatais, ou seja, representa uma sociedade burguesa separada do Estado, uma visão em que o burguês ou empresário é comparado com um indivíduo, já os sociais representam uma via de acesso às instâncias do Estado ao penetrar, procurando conhecê-lo e controlá-lo, ou seja, faze parte da constituição do Estado. A terceira característica diz respeito às condições de aplicabilidade e eficácia. Os direitos sociais só podem ser concretizados por meio de políticas públicas, que requerem vontade política e grandes quantias de recursos materiais e financeiros. Por isso, os 
liberais acusam que os direitos sociais são de difícil concretização, seja por falta de recursos, ou seja, por falta de vontade política. Logo, acabam virando letra morta e esvaziando sua condição de direito fundamental.

Nesse sentido, pode-se perceber que a política social está associada ao reconhecimento da questão social como direito, uma realidade concreta, sendo um fenômeno estritamente relacionado à constituição da sociedade burguesa, onde a partir do Estado Social (Bem-Estar), elas vão ganhar amplitude e solidez. Dessa forma, afirma-se que a política social do Welfare-State é um fenômeno eminentemente do Estado capitalista, pois ela surge como meio de o Estado intervir na sociedade e na economia de forma que os seguros dos capitalistas fossem salvaguardados.

Apesar de muito se pensar que a política social e o Welfare-State ou Estado de Bem-Estar são a mesma coisa, isso não é de todo verdadeiro. A partir da lógica linear da história, onde a política social evoluiu ao longo do tempo até chegar à política social aplicada pelo Estado de Bem-Estar, as primeiras intervenções do Estado na sociedade, para se combater a pobreza mesmo que de forma coercitiva e punitiva para o pobre, seriam medidas consideradas como o primeiro estágio, ou início da política social, na qual ao longo do tempo chegou como uma forma de seguro social ou proteção social pelo Estado Social. Mas a política social não pode ser tomada por esse caráter linear segundo Pereira (2008) posto que as medidas de intervenção do Estado para com a sociedade destinada à resolução de problemas sociais refletem o caráter do Estado de determinada época. Como por exemplo, no caso da Poor Law's ou lei dos pobres ela pode ser considerada como uma política social que espelha um Estado absolutista e não uma "protoforma" de política social. As políticas sociais de alguma forma sempre existiram e foram respostas aos problemas de caráter social que dependiam da relação que o Estado vigente tinha com a sociedade de cada época.

O Estado de Bem Estar Social é resultante do desenvolvimento do capitalismo "rumo à industrialização" e a formação dos Estados nacionais. De acordo com Mishra (1991) apud Pereira (2008) a realidade específica que esse Estado se desenvolveu foi a do capitalismo regulado que entrou em vigência a partir da segunda guerra mundial.

Ao final do século XIX a sociedade, a economia e a política passaram por transformações que influíram grandemente no Estado e na política social dele. Essa nova etapa dos países capitalistas centrais exigiu do Estado "novas intervenções" inaugurando um novo modelo de proteção social. Esse novo tempo foi associado por 
alguns autores como Asa Briggs (2000) apud Pereira (2008) com o surgimento dos seguros sociais alemães criados por Otto Von Bismark que abriria espaço para o Welfare State. O Desencadeamento desse modelo de Estado de acordo com Pereira (2008) se daria por acontecimentos históricos como: a transformação das técnicas de produção (a Revolução industrial); a democracia das massas (República) e por último a formação dos Estados Nacionais (Países), acontecimentos esses que inclusive foram identificados por autores clássicos como Tocqueville, Weber, Marx, Durkheim.

O Estado que nasceu por esses fatores históricos passaria a ser um mediador entre os conflitos sobressalentes entre a polarização das classes sociais como o capital e o trabalho, acirradas pela expansão do capitalismo junto à opressão e alienação massiva dos trabalhadores.

A partir do momento diferente do período pré-industrial, não significa que o pauperismo nunca tenha existido, mas no século $\mathrm{XX}$, por questões históricas, esse fenômeno foi deflagrado como seqüela da então instaurada questão social. Então o "social" passou a ser encarado de outra forma. Reconhecendo-se contradições entre a ordem econômica vigente e a concretização dos direitos dos cidadãos pautados nos ideais liberais da revolução francesa, sinalizava mudanças nas novas relações entre o Estado e a sociedade. As sociedades industriais passaram a ser sinônimas de progresso técnico, democrático e bem-estar institucionalizado, previsto em lei por meio do Estado Social. Dessa forma, o Welfare-State passaria a ser um divisor de água entre um sistema de proteção pré-industrial e carente de riquezas e, outro moderno, industrial e próspero.

Neste sentido, a política social, após a institucionalização do Estado de Bem Estar ou Welfare-State, como fenômeno histórico particular situado normativamente no segundo pós-guerra (Mishra, 1995 apud Pereira, 2008) vai ser um instrumento de intervenção positiva do Estado na sociedade, garantindo direitos sociais de cidadania. A correlação de forças, que transpassa o bojo da política social com todas as suas implicações, nesse período, vai se colocar mais clara e evidente, porque a política social enquanto instrumento de regulação social está permeada, historicamente, de justificações morais e ideológicas. No segundo pós-guerra, isso, não se dará diferente, pois a política social além de ser uma forma de regulação com potencialidades de atender a diferentes interesses, até mesmo contraditórios, se colocará num processo dinâmico e conflituoso. 
O Estado de Bem Estar, produto do sistema capitalista, representa mais um momento histórico da sociedade do que um Estado de fato. Tem como principal intencionalidade salvar o sistema que se encontra em crise, por isso as justificações teóricas e ideológicas, assim como o acervo técnico profissional, como as (os) assistentes sociais daquele contexto sócio-histórico, se objetivavam para a legitimação e reprodução desse sistema.

Deste modo, o complexo moderno de proteção social amparado por conceitos de cidadania social e seguridade, surge a partir do momento em que os rumos liberais adotados pelo sistema capitalista deixam de ser apreendidos, por sua própria sobrevivência, como corrente direcionadora do planejamento econômico, político e social para dar espaço ao Estado interventor. O surgimento do Estado de Bem Estar, como intervenção estatal deve conciliar, por sua vez, as demandas por maior igualdade e reconhecimento de direitos sociais, assim como, também, manter recicladas e preservadas as demandas dos capitalistas.

A racionalidade que fundamentou as ações do Estado de Bem Estar se baseou em três marcos orientadores que juntos formam o paradigma dominante desse tipo de Estado (Pereira, 2008). São eles: o receituário Keynesiano de regulação econômica e social, inaugurado nos anos de 1930; as postulações do relatório de Berveridge sobre a Seguridade Social e as formulações da teoria da cidadania elaborada por T. H. Marshall. O receituário de Keynes tinha como objetivo o equilíbrio econômico por meio de intervenções do Estado a partir do déficit público, ou seja, o Estado deveria se endividar garantindo pleno emprego para que o consumo fosse socializado e isso por sua vez aqueceria a economia, pois todos os produtos ofertados pelo mercado teriam consumidores dispostos ao consumo. Então Keynes concebeu medidas estatais que ao gerar dispêndios públicos removeria o desemprego e manteria um ambiente propício a criação de novos empregos, ocorrendo assim o que se chamaria de pleno emprego para Keynes não seria o livre mercado que possibilitaria o equilíbrio econômico e sim o pleno emprego movido por forças externas, ou seja, o Estado segundo Pereira (2008). Desse modo, o objetivo do desenvolvimento de políticas econômicas keynesianas vinculadas a um Estado de Bem Estar seria preservar o crescimento econômico sob condições de pleno emprego, desenvolvendo políticas sociais que possibilitassem a redistribuição do crescimento econômico, controlando os efeitos sobre a população e ao mesmo tempo compensando àqueles que pagaram o "preço" por esse crescimento. 
Sustentado pelo receituário Keynesiano, surge na década de 1940, o relatório de Berveridge sobre o seguro social e os serviços de mesma natureza. Esse relatório propunha uma extensa revisão sobre a forma de proteção social da Grã- Bretanha. O sistema de seguridade social de Berveridge inovou por unificar todos os esquemas de pensões, saúde e seguro desemprego existente na Inglaterra em um sistema único e nacional extinguindo os testes humilhantes que as pessoas eram submetidas para conseguirem esses benefícios. Em sua composição existia assistência pública do Estado com eixo distributivo e contributivo ao mesmo tempo. A partir da institucionalização desse sistema de proteção social pelo governo trabalhista Inglês Clement Attle, as políticas sociais passaram a serem concebidas como direito (Roche, 1992 apud Pereira, 2008).

Em 1946, houve a edição da lei nacional do seguro e a aprovação da Lei Nacional de Assistência em 1948. Essa lei previa o auxílio-doença e desemprego; pensão aos aposentados; auxílio maternidade, viuvez e funeral. Essa lei pode ser considerada como um contrapeso a lei dos pobres (Timmins apud Pereira, 2008). Podese destacar a partir do relatório de Berveridge a criação de um Sistema Nacional de Saúde não contributivo e universal como pilar do sistema de seguridade social.

Apesar dos avanços proporcionados pelo relatório de Berveridge ele ainda apresentou resquícios liberais muito fortes, segundo Pereira (2008), pois a assistência social pública era pautada nos mínimos para a reprodução da força de trabalho, ou seja, esse auxílio mínimo funcionava como um mecanismo de incentivo às pessoas para o trabalho e a auto-provisão. Além de que a proteção social era voltada para a família sob forma de mantê-la unida sob o comando do homem para a reprodução do sistema com a colaboração do trabalho doméstico e gratuito da mulher.

O Estado de Bem Estar foi legitimado teoricamente por meio da sistematização da teoria da cidadania do sociólogo T. H. Marshall, onde os serviços sociais públicos foram inseridos como direitos de cidadania e cabia a esse respectivo Estado sua execução e garantia. De acordo com Potyara Pereira a teoria de Marshall foi "um suporte acadêmico de peso" (p. 95) às políticas sociais de cunho Keynesiano e Berveridgiano, pois esses não passaram de doutrinadores.

Para Marshall de acordo com Pereira (2008) a cidadania era composta por três grupos de direitos sendo eles os civis, os políticos e por último os sociais sendo eles conquistados respectivamente nos séculos XVIII, XIX, XX. Esses direitos, segundo ele, 
foram conquistados a partir da luta de movimentos democráticos passando a serem reconhecidos pelas instituições públicas. Os direitos civis são assegurados em forma de leis e os tribunais de justiça vigiam por seu cumprimento, esses direitos dizem respeito aos individuais, o de ir e vir e os de propriedade. Já os políticos relacionados ao voto e o poder de ser votado estão no âmbito da democracia parlamentar e dos conselhos de governo local. Por último, os mais novos dos direitos: os sociais, eles estão no perímetro dos serviços sociais fundamentais ao ser como aqueles referentes ao sistema educacional e os próprios da seguridade social como a saúde, assistência pública ao provimento do ser e a previdência, como garantia futura aos trabalhadores (as). Os direitos sociais, para Marshall (1967) apud Pereira (2008), devem compreender tudo que vai do bem estar econômico ao direito de participar da plenitude dos benefícios que a sociedade pode oferecer aos seus habitantes

Desse modo, no caso brasileiro, quando falamos de Assistência Social como direito estabelecido pela Constituição Federal de 1988, tem-se uma ampliação do raio de cidadania para aqueles que pertencem ao exército industrial de reserva ou para os que se encontram em risco e vulnerabilizados (as) por condições estruturais inerentes as próprias fragilidades humanas podendo, assim, ficarem protegidos (as) pelo Estado por meio de sua postura afirmativa ou positiva na sociedade.

\subsection{Trajetória da Política de Assistência Social no Brasil de 1930 ao século XXI}

Constituir a Assistência Social, recuperando a história é imprescindível, pois a partir dessa composição pode-se chegar a determinantes estruturais e históricos que viabilizam o entendimento das relações em que essa política se dá hoje, permitindo avaliar quais são os seus avanços e os retrocessos, identificando os seus limites e potencialidades no contexto de revolução sociotécnica e informacional do século XXI.

Assim sendo, essa construção histórica e feita nesse sub capítulo a partir da leitura de Sposati \& Falcão (1989), Sposati (2004). Na contemporaneidade toma-se como referência a PNAS como a síntese resultante do confronto entre o conservadorismo das ações socioassistenciais versus as práticas e concepções revolucionárias e progressistas da Assistência Social como direito do cidadão e dever do 
Estado em provê-la. Tomando a perspectiva revolucionária e progressista o Estado e os atores responsáveis por sua execução não podem se absterem do uso das NTICs, com espaço ao controle democrático, para a implementação dessa política, nos moldes de gestão descentralizado e participativo.

A Assistência Social enquanto política social, garantidora de direitos tem sua germinal existência, no Brasil, a partir do despontamento do Estado de Bem-Estar social que se consolidaria no pós II guerra mundial. A partir desse momento o reconhecimento da questão social, enquanto um ponto de enfrentamento do Estado, é que se pode contextualizar a Assistência Social no seu caráter histórico de surgimento como política pública.

A atual Política de Assistência Social concretizada por meio de um Sistema Único de Assistência Social (SUAS) rompe com a condição primária e histórica da política social, nos primórdios de sua criação, que a caracterizava como caridade, benesse, amadorismo, boa vontade, sobreposição de objetivos, paralelismos das ações e finalidades. O SUAS (Sistema Único de Assistência Social) propicia uma racionalidade técnico-operativa a política baseada na perspectiva do direito social garantido pela Constituição Federal Brasileira de 1988, o que se abandona por completo as origens arcaicas e difusas do seu nascimento.

A origem da política de Assistência Social se deu por meio da instituição que por muito tempo teve a "missão" de prestar ações e serviços assistenciais a população brasileira, a LBA (Legião Brasileira de Assistência) é exemplo disso. A LBA, quando surgiu em 1942, ficou encarregada em dar apoio às famílias dos soldados brasileiros que foram arregimentados para combaterem na $2^{\circ}$ Guerra Mundial. A esposa do presidente Getúlio Vargas, Dona Darcy, liderou um grupo de mulheres para participar do esforço de guerra que se havia instalado no país e aliada às voluntárias fizeram um conveniente trabalho, e quando acabou a guerra, decidiu-se que a Legião "continuaria a fazer na paz o que fez muito bem na guerra" 9 .

Até a década de 1930, o Brasil assumia os problemas decorrentes da questão social como um problema de polícia e não como problema de política social. Entretanto após o Tratado de Versalhes que assumia o compromisso, de amparo aos trabalhadores, nos pós I guerra, fez com que o Brasil apresentasse esse seguro aos trabalhadores,

\footnotetext{
9 Comentário feito pelo presidente Sarney no programa "Conversa ao Pé do Rádio" por ocasião do quadragésimo quarto aniversário da LBA, 1986 apud SPOSATI \& FALCÃO, 1989, p. 13.
} 
mesmo que de forma débil e precária a partir da regularização das Caixas de Aposentadoria de Pensões (CAP), mas a grande maioria da população ficava desprotegida relegada às iniciativas da sociedade civil, representada pelas Santas Casas, Beneficências e Associações de Socorro Mútuo.

A LBA como "missão legionária da sociedade civil" registrada em 1942 no Ministério da Justiça e Negócio Interiores como sociedade civil com finalidades não econômicas com o intuito de centralizar as organizações de assistenciais de boa vontade se institucionalizou como entidade assistencial para a prestação de serviços pertinentes ao que se chama, hoje, de sócio-assistencias. Além do seu vínculo institucional com o Ministério da Justiça, ela era associada, também, ao Ministério do Trabalho, Indústria e Comércio responsável pela aplicação dos recursos. Os recursos eram advindos da colaboração entre empregados, empregadores e a União, instituído pelo Decreto-Lei $\mathrm{n}^{\circ}$ 4830 de $15 / 10 / 1942$.

As primeiras damas dos governos estaduais têm nesse momento um forte protagonismo para a concentração de forças sociais para o atendimento das famílias dos pracinhas, mobilização da sociedade civil, promoções de campanhas para aquisição de matérias primas para fabricação de produtos destinados à guerra, além da promoção de campanhas para obter fundo para a própria instituição (Sposati \& Falcão, 1989). A LBA se colocava como uma mãe para a sociedade com traço paternalista forte que prestava auxílios emergenciais e provisórios à miséria. Desta forma, a instituição da LBA acentuava fortemente o populismo na relação entre o Estado e a sociedade civil.

O quadro funcional de trabalhadoras dessa instituição era composto por voluntárias e poucos servidores públicos cedidos para o trabalho com as primeiras damas. Pode-se destacar, nesse período como o papel feminino construído e atribuído socialmente as mulheres como: a ternura, compaixão, espírito de voluntariado e devoção foi aproveitado para o enfrentamento da questão social no pós II guerra para o amortecimento e suavização dos problemas relacionados à pauperização, desproteção, vulnerabilidades e debilidades do segmento da sociedade "subalterno ${ }^{10}$ ".

Nesse período de ação da LBA não era contínua e permanente, mas ocorria em situações ocasionais e emergentes como no caso de calamidades públicas, tipo:

10 Conceito trabalhado por YASBEK, Maria Carmelita no livro classes subalternas e assistência social, 1999. 
enchentes, secas etc. Agora com o surgimento das Comissões Estaduais e Municipais da LBA, que efetuaram o aparecimento embrionário da ação oficial da Assistência Social como órgão Federal, entretanto essas Comissões não modificaram a natureza do trabalho da instituição. Essas Comissões eram formadas por:

"um presidente representado pela primeira dama, um secretário e um tesoureiro indicados pela Associação Comercial do Estado, um grupo de voluntários e uma meia dúzia de servidores públicos" 11 .

As Comissões como unidades regionais se organizaram em torno de um espírito de patriotismo que impulsionava a sociedade civil por meio da mobilização para enfrentar a situação de guerra. Para isso, as Comissões contavam com o trabalho e missão das primeiras damas, o apoio das associações empresariais, a cobertura complementar das ações do governo e a formação de uma rede de voluntariadas. Essas Comissões Estaduais eram pautadas na mesma lógica da LBA com os mesmos valores arraigados de ajuda, benevolência, caridade, sobreposição de objetivos e finalidades, sendo entidades juntamente com a própria LBA com critérios e diretrizes obscuros à sua fundação e funcionamento enquanto instituição social.

Em 1945, no pós II guerra mundial, quando o pacto interclasses, que originará o Welfare-State, tomar forma, os serviços sociais passariam a ser providos para todos os cidadãos, não obstante esse modelo de seguro social não chega ao Brasil, porque essa proteção era restrita e dada somente para alguns trabalhadores de categorias específicas. Dessa forma, a grande maioria da população brasileira, que não possuía um vínculo formal de trabalho em categorias profissionais determinadas, ficava a mercê dos programas compensatórios, ou das benesses por parte do Estado, ou da sociedade civil. A liberdade dos trabalhadores informais — os pauperizados — ganhou uma condição de vigilância deixando de serem cidadãos para virarem necessitados assistidos. Cria-se nesse sentido dois tipos de sujeitos históricos: os cidadãos merecedores de previdência social e os subalternos dignos da tutela e benesse do Estado, recebendo assim dele, de forma caritativa e paternalista, os benefícios referentes à Assistência Social. Desde então se reforça na sociedade brasileira a cultura e o senso comum de que a Assistência Social seria algo ruim, porquanto o seu caráter não estava associado à cidadania, sendo 
um favor do Estado e não um direito do trabalhador. Por conseguinte, se ela fosse prestada por trabalhadoras despreparadas, voluntariados; suas ações fossem desajustadas, descabidas, fragmentadas pragmáticas e os recursos escassos, não teria problema, pois os (as) usuários (as) desses serviços ainda estariam ganhando, porque isso não deveria nem existir, pois como conceituava ser um favor, se fosse ofertado de qualquer forma, não teria problema.

Apesar da cultura de favor da Assistência Social, ela já aparecia no final da década de 1940 como um complemento fundamental das políticas sociais quando se prestava a atender, por alguns de seus serviços, à massa de trabalhadores excluídos e pauperizados (Sposati \& Falcão, 1989).

Na década de 1950, onde a modernização do Estado comandada por Juscelino Kubitschek com a construção das hidrelétricas, implantação da indústria automobilística e a siderurgia nacional e a implantação gradativa de órgãos estatais destinados a implementação de políticas sociais. Os programas sociais possuem um forte caráter assistencialista, respondendo às necessidades do capital como o preparo de mão de obra, o consumo dos bens produzidos e o controle social das camadas populares. Assim, a LBA segue sua trajetória recebendo doações e se fixa como órgão paralelo à ação governamental. $\mathrm{O}$ volume das suas ações assistenciais aumentaria como a manutenção de instituições "carentes", auxílio econômico, o amparo e o apoio à família, orientação maternal, campanhas de higiene, fornecimento de filtros, assistência médicoodontológico, manutenção de creches e orfanatos, colônia de férias e a concessão de instrumento de trabalho. Desse modo, percebe-se que as ações assistenciais eram totalmente diversas, não tendo um eixo de norteamento das ações, o que ocasionava o paralelismo, a indefinição e o obscurecimento do que seria Assistência Social, ora, ela era tudo e, ora, era nada. Os equipamentos sociais da LBA instalados nos estados eram as casas da criança, postos de puericultura, hospitais infantis, maternidades e educandários.

No regime militar na década de 1960, a LBA tem seus recursos ainda mais reduzidos embora ela se institucionalize cada vez mais como um órgão federal e seus recursos passam a ser advindos do FGTS (Fundo de Garantia por Tempo de Serviço) quer, onerando cada vez mais o trabalhador pela sua instabilidade imposta pelo capital. Nesse período, o discurso acadêmico vai marcar uma separação entre a Assistência Social e a Promoção Social argumentando que o Estado não deveria dar o peixe e sim 
ensinar a pescar, logo, as ações assistenciais vão ser ainda mais rejeitadas, os programas assistenciais passam a ser pautados em torno de uma educação social para o mercado de trabalho.

Em 1968, o fundo da LBA passa a ser financiado pela loteria esportiva onde 40 $\%$ de sua renda líquida deveria ser destinada aos programas assistenciais da LBA. E somente em 27 de maio de 1969, a LBA deixa de ser um órgão legionário para ser uma fundação vinculada ao antigo Ministério da Previdência Social, mas, sua natureza não muda, ela continua ser de direito privado.

Na década de 1970, o Estado cria múltiplos organismos de Assistência Social a nível Federal, Estadual e Municipal para lidar com a pobreza, entretanto, por as competências entre as três esferas de governo não ficarem definidas e claras acabava ocasionando o paralelismo das ações assistenciais. Somente em 1974, com a criação do Ministério da Previdência e Assistência Social por meio da lei ${ }^{\circ} 6.036$ é que a FLBA (Fundação Legionária Brasileira de Assistência) rompe com seu status legionário e ganha um novo estatuto, agora, como órgão governamental e com recursos provenientes do Fundo de Apoio ao Desenvolvimento Social. A partir desse momento a FLBA passa a ser um dos órgãos componentes do Sistema Nacional de Previdência Social (SINPAS), o que marca a nova fase na busca pela sua identidade.

Ainda na década de 1970, a LBA tem seus recursos ampliados em 100\% e passa a ser respaldada cada vez mais por estudos acadêmicos, embora esses estudos rechaçassem o auxílio assistencial do governo. Traz a concepção da Promoção Social por meio da educação, o que hoje se sabe que não é de todo verdadeiro, pois a realidade do mercado de trabalho tende a demandar por trabalhadores bem capacitados, mas em número reduzido, o que quer dizer, a ampla maioria da população ficará com trabalhos precários e informais, assim, a Assistência Social, como proteção estatal, se faz necessária na atualidade, onde o mercado concorrencial, não pode abarcar toda a demanda de trabalhadores, logo esse discurso que diz o contrário disso é uma falácia, nesses tempos de crise do capital.

O fenômeno da pobreza passa então, na década de 1970, a ser "estudado, analisado e minorado" (Sposati \& Falcão, 1989, p. 26). A pobreza é reconhecida pelo governo, mas como um fenômeno sem sujeitos e sim com indivíduos incapacitados, carentes que não possuem capacidade de interlocução. A tecnocracia passa a ser a forma de elaboração, planejamento e implantação da política, e em gabinete, um grupo 
"seleto" de pessoas decidia a política por meio de números e indicadores sem o conhecimento da realidade, dos anseios, e das necessidades pessoais a quem a política se destinava.

A FLBA, ainda, nesse período, passou a ser associada como um banco para gerir a pobreza, onde os recursos eram alocados e consecutivamente destinados à criação e à manutenção de programas sociais como o desenvolvimento comunitário e os serviços padronizados em escala. No entanto, a FLBA desencadeará uma multiplicidade de programas abarcando várias questões que fugia até da sua natureza recém instituída, que em síntese, era um banco da pobreza e seu direcionamento resultava na fragmentação de suas ações.

Na década de 1980, a FLBA, como instituição responsável por prestar a Assistência Social no Brasil, em plenos ares democratizantes, tem sua concepção de voluntariado para o atendimento dos mais necessitados, reforçada, pela então presidente da FLBA Léa Leal.

Somente em 1988, com a promulgação e a ampliação e reconhecimento de direitos do cidadão pela então Carta Magna que se estabeleceu o marco legal que viabilizará originalidade para uma nova concepção de Assistência Social, no seu art. 203 e 204. A Constituição estabelecerá que a Assistência Social componha o rol da seguridade brasileira, juntamente com a previdência e a saúde devendo ser uma política pública garantida como dever do Estado em provê-la e direito do cidadão em recebê-la. A Assistência Social como direito prescrito na Constituição Federal repudia o conceito de população beneficiária, marginal ou carente, porquanto esses conceitos têm um sentido vitimizador dos sujeitos, pois suas necessidades não advêm de sua condição individual, mas sim social. São problemas estruturais. Logo, as medidas para saná-las devem ser estruturais (Sposati, 2004) e com o protagonismo do usuário é claro.

Desse modo, ao corrigir os erros do passado a Constituição estipulará que a Assistência Social deverá ser implementada em um sistema descentralizado, participativo e com garantias de alocação dos recursos financeiros (Sposati, 2004) para atender a nova perspectiva do direito. Assistência Social deve superar a fragmentação, descoordenação e a superposição de programas sociais, e atingir controle fiscal do setor público dos recursos repassados às entidades privadas inserindo mecanismos de avaliação e controle democrático. Embora a Constituição tenha reconhecido direitos e proporcionado avanços, a Política de Assistência Social continuou sendo implementada 
de forma conservadora reproduzindo as velhas práticas da FLBA, apesar do momento fecundo para o estabelecimento de uma nova política de proteção social assistencial do Estado, ela não foi concretizada como estava predita na Constituição/1988. Na década de 1990, o Brasil ao acompanhar o modelo político-econômico e social externo adota o modelo neoliberal que atualizaria as velhas práticas liberais do passado. Assim, Lei Orgânica que regulamentaria a Assistência Social após aprovação nas estâncias legislativas é vetada pelo então presidente, da época, Fernando Collor de Melo. Somente após intensa articulação política entre a sociedade civil organizada como a categoria profissional do Serviço Social; movimentos sociais; e os conselhos de direitos, o presidente, que sucedeu Collor, Itamar Franco, aprova a LOAS em 1993 (Sposati, 2004), que dispõem sobre a organização da Assistência Social e dá outras providências.

A LOAS regulamenta os preceitos constitucionais sobre a Assistência Social reafirmando-a como política de Seguridade Social no campo dos direitos sociais (Brasil, 2008). Desse modo, ela torna possível a Assistência Social como um dever de Estado e direito à cidadania, sem contribuição prévia (Brasil, 2008). Nos 42 artigos, essa lei dispõe sobre:

"os princípios e diretrizes dessa política; a forma de organização e gestão das ações; às competências das esferas de governo; ao caráter e composição das instâncias deliberativas; instituição e competências do Conselho Nacional de Assistência Social (CNAS); as competências do órgão nacional gestor da Política Nacional de Assistência Social; ao conceito de benefícios, serviços, programas e projetos; e por último sobre o financiamento dessa política" (Brasil. CapacitaSUAS, 2008, vol. 1, p. 101).

A LOAS estabelece um novo eixo para a Assistência Social brasileira, iniciando um processo com o objetivo de torná-la visível (Brasil, 2008) e umas das primeiras medidas nessa orientação foi o estabelecimento dos conselhos deliberativos e paritário nas três esferas de governo o que proporcionaria configurar a Assistência Social "a partir do reconhecimento público da legitimidade das demandas de seus usuários e espaço de ampliação de seu protagonismo" (Brasil. CapacitaSuas, 2008, vol. 1, p. 102).

Em 1997, foi editada uma Norma Operacional Básica de Assistência Social (NOB) visa a concretizar os princípios e diretrizes da LOAS conceituando o Sistema Descentralizado e Participativo; ampliando-se as competências dos governos Federal, Municipais, Estaduais e o Distrito Federal; e instituir a exigência do conselho, plano e 
fundo para que o Município pudesse estar habilitado e, assim, receber recursos Federais (Brasil, 2008)

No ano de 1998, uma nova edição da NOB, os serviços, programas e projetos são diferenciados; as atribuições dos Conselhos de Assistência Social são ampliados; os espaços de negociação e pactuação entre os gestores das três instâncias governamentais são criados (Brasil, 2008).

Já em 2003, realizada pelo Conselho Nacional de Assistência Social (CNAS), a IV Conferência Nacional de Assistência Social fortaleceu o reconhecimento da gestão democrática e descentraliza da Assistência Social recomendada pela LOAS. Nesse sentido foi definido, nessa Conferência, que deveria ser criado um modelo de gestão que abarcasse essas diretrizes. Esse modelo passaria a ser chamado de Sistema Único de Assistência Social (SUAS) (Brasil, 2008).

Em 2004 com a criação do Ministério do Desenvolvimento Social e Combate à Fome (MDS) é instituída a Secretaria Nacional de Assistência Social (SNAS), que acelera e fortalece o processo de construção do SUAS até os dia atuais implementando os novos eixo sócio-assistenciais como o direito do cidadão e o dever do Estado (Brasil, 2008). Uma das iniciativas desse processo de construção do SUAS, iniciado por esta secretaria (SNAS) é a criação da Rede SUAS, um sistema de informação concatenado aos princípios, objetivos e diretrizes do SUAS. O sistema efetiva a adesão por parte das três esferas de governo, monitorando, avaliando por meio da informação gerada, alocada e distribuída na rede social (Brasil, 2008).

Dessa forma, a Rede SUAS se insere no contexto das Novas Tecnologias de Informação e Comunicação é um passo inovador no trato das informações sócioassistenciais, inaugurando uma nova fase para essa área. Deste modo, no século XXI, o SUAS e sua respectiva rede tecnológica de informação e comunicação atendendo ao fenômeno da "Revolução Informacional", onde as informações estratégicas para a gestão devem circular independente de hierarquias (Lojkine, 1995), é um suporte fundamental para a gestão do SUAS em todo território nacional, alcançando todos os setores profissionais e instâncias envolvidas na operacionalização dessa política, viabilizando um melhor controle democrático ${ }^{12}$, por meio dos conselhos, e acesso ao usuário do direito (Brasil, 2008).

12 Conceito trabalhado por Potyara Pereira quando a sociedade civil por meio dos conselhos gestores que sendo tratados como órgãos consultivos e deliberativos colaboram para a gestão das políticas 


\subsection{O SUAS estabelecendo uma nova concepção de Assistência Social:}

O Sistema Único de Assistência Social (SUAS) é resultante de uma nova orientação política da gestão das ações descentralizadas e participativas de Assistência Social no Brasil ${ }^{13}$. O SUAS é uma inovação, produto de uma luta histórica e legítima dos usuários (as), trabalhadores (as), intelectuais, categorias profissionais - como o Serviço Social - que há muito militam na área para o reconhecimento de uma necessária demanda inerente à sociedade capitalista, o direito a Assistência Social pública de qualidade com espaço para o controle democrático e dever do Estado para o segmento despossuído que - essa - determinada sociedade constrói.

Nesse sentido, a IV Conferência Nacional de Assistência Social realizada em 2003 deliberou sobre a implantação do SUAS como modelo de gestão para todo território nacional, objetivando consolidar um sistema descentralizado e participativo instituído pela Constituição Federal Brasileira de 1988 e a Lei Orgânica de Assistência Social em 1993 (PNAS, 2004).

A Constituição Federal de 1988, no seu art. 204, especifica que a política deve ser consolidada com um regime geral de gestão próprio integrada entre os três entes federados: o Município, o Estado e a União, com participação popular sob o modelo público não-contributivo e não lucrativo de gestão (PNAS, 2004) dada intersetorialmente com as demais políticas públicas brasileiras e não de forma excluída e destacada do rol de proteção social estabelecido pela seguridade social brasileira.

De acordo com a PNAS (2004), o SUAS concretiza o modo de gestão compartilhada com o cofinanciamento e a cooperação técnica entre os três entes

públicas como a saúde, a assistência social, a educação e a previdência. Esse conceito é preferido pela autora, ao invés de controle social porque esse segundo é mencionado por autores clássicos - como Durkheim e Weber - às ações do Estado para o controle da sociedade. Os conselhos gestores com participação da sociedade civil exercitam a democracia direta diferente da democracia convencional na qual a sociedade elege um representante para cuidar de seus assuntos políticos. Com a Constituição Federal de 1988 do Brasil institucionalizando a descentralização e a participação das políticas públicas representa uma nova era para a implementação das políticas sociais, onde os demandantes dessas controlam as ações do Estado para seu melhor uso em benefício de todos (Pereira, 2005).

13 Norma Operacional Básica do SUAS (NOB/SUAS) contida na Política Nacional de Assistência Social, 2004. 
federados para que ela se dê de forma integrada e articulada, ao implementar a política no campo de proteção social público de fato. Em vista disso, o SUAS estabelece a divisão das responsabilidades "para instalar, regular, manter e expandir as ações de Assistência Social como dever de Estado e direito do cidadão no território nacional" (PNAS, 2004, p. 86). Ao contrário da política de Assistência Social feita pela LBA, onde se tinha uma sobreposição de objetivos e propósitos não evidentes, o SUAS, dirigido pelo Ministério do Desenvolvimento Social e Combate à Fome (MDS), orientase pela unidade de propósitos e objetivos que direciona o alcance dos direitos aos usuários dessa política.

Em todo território nacional, a hierarquia, os vínculos e as responsabilidades vão ser regulados pelo SUAS que vai organizar, num comando único, em cada esfera de governo, os serviços, os benefícios, os programas, os projetos e as ações de Assistência Social (PNAS, 2004). O parâmetro da consolidação desse sistema será guiado pela lógica universal, funcionando em rede hierarquizada nas competências a nível Municipal, do Distrito Federal, Estadual e Federal. O SUAS deve respeitar as diversidades regionais e suas respectivas diferenças sócio-culturais, econômicas e políticas se configurando a partir da realidade de cada cidade brasileira e da sua população urbana e rural. Os eixos estruturantes da gestão do SUAS de acordo com a PNAS (2004) são:

- A viabilização da política como gestão pública;

- Efetivação dos direitos sócio-assistenciais pelos usuários;

- Matricialidade sócio-familiar;

- Territorialização;

- Descentralização político-administrativa;

- Financiamento partilhado entre os entes federados;

- Fortalecimento da relação democrática entre o Estado e a Sociedade Civil;

- Valorização da presença do controle democrático;

- Participação popular/cidadão usuário;

- Qualificação de recursos humanos;

- Informação, monitoramento, avaliação e sistematização dos resultados.

O SUAS deve abarcar os planos Municipais, Estaduais e Federal de Assistência Social, orientados conforme a Lei Orgânica de Assistência Social (LOAS). Esses planos 
devem ser aprovados pelos conselhos de assistência social na sua respectiva esfera de governo, sendo que estes devem ser pautados pela Política Nacional de Assistência Social. A PNAS, por sua vez, deverá ser aprovada pelo Conselho Nacional de Assistência Social (CNAS), que é a estância máxima de deliberação e de direção da política, juntamente com as Conferências Nacional, Estadual e Municipal de Assistência Social realizada a cada biênio. Isso demonstra que esse sistema deve ser construído cotidianamente em caráter democrático e participativo levando em consideração as demandas e necessidades da população local usuária dos serviços, programas, projetos, benefícios e proteção social do Estado perante os casos de riscos, vulnerabilidades e iniqüidades sociais que os afligem.

O SUAS ainda tem como princípios norteadores de sua aplicação na sociedade: a existência de espaços institucionais para colher a manifestação dos interesses dos usuários, ação e preservação dos seus direitos sócio-assistenciais e medidas e procedimentos contra a violação desses direitos. As ações das entidades públicas e privadas de prestação de serviços, programas, projetos e benefícios socioassistenciais devem ser fiscalizadas e reguladas garantindo o controle da qualidade das respectivas ações. O SUAS também exige um sistema de gestão orçamentária para sustentar as ações da Política de Assistência Social, por meio do orçamento público com provisão de custeio, para a rede socioassistencial estabelecida em cada esfera de governo a partir do cálculo dos custos dos serviços socioassistenciais por elemento de despesa por lidar com recurso público esse sistema exigirá transparência na prestação de contas; mecanismos de transferências fundo a fundo e uma relação clara dos entes federados como fonte financiadores dessa política.

Além desses princípios o SUAS prima pelo relacionamento das gestões interinstitucionais, intersecretarias, intermunicipais, metropolitanas, por meio "de ações complementares, protocolos, convênios, fóruns de gestão, mecanismos de responsabilidade social, intercâmbio de práticas e de recursos" (PNAS, 2004, p. 88)

No relacionamento interinstitucional, o SUAS explicita a articulação com os demais sistemas de defesas dos direitos como os que dizem respeito aos direitos da criança e do adolescente, dos idosos, das pessoas com deficiência, mulheres, negros; a proteção às vítimas de exploração e violência; adolescentes ameaçados de morte; promoção ao direito ao convívio familiar. O SUAS deve se relacionar, também, com o Sistema Único de Saúde (SUS), a partir de rede de serviços complementares como proteção às pessoas 
em estado de drogadição, vítimas de violência familiar e sexual, deficiência, fragilidades pessoais, problemas de saúde mental, abandono em qualquer momento da vida que estejam associados às vulnerabilidades pessoais. Os vínculos, entre a proteção social contributiva e a não contributiva, devem ser articuladas entre SUAS e o sistema previdenciário. Há, ainda, articulação do SUAS com o Ministério da Justiça no que diz respeito ao sistema nacional e estadual de justiça como: a proteção às crianças e adolescentes vítimas de violência e abandono, e aplicação de medidas sócio-educativas. Por final, o SUAS deve ser articulado com o Sistema Educacional por meio "de serviços complementares e ações integradas para o desenvolvimento da autonomia do sujeito" (PNAS, 2004, p. 88), educando-o (a) para o trabalho emancipado e não o alienado.

O SUAS tem como objetivo concretizar a política social da Assistência Social como pública incluída no rol da seguridade social brasileira como prediz a Constituição Federal de 1988 em seu art. 203 e 204. Todos, que têm necessidade dessa assistência específica do Estado, devem dispor dela em caráter universal sem contribuição prévia para o acesso aos serviços, programas, projetos, e benefícios que essa política por intermédio do SUAS dispõe, por isso, seu caráter é eminentemente cidadão com a potencialidade de aprofundar e difundir os direitos sociais na sociedade (PNAS, 2004).

Dessa forma, o SUAS rompe, no Brasil, com a linearidade histórica do assistencialismo, populismo, caridade, ajuda, pragmatismo, troca de favores, fragmentação, desplanejamento, tutela e apadrinhamento que a assistência do Estado ou da esfera privada ao longo da história prestava aos despossuídos, formando um grande ciclo vicioso de dominação e subjugação dos menos favorecidos. O SUAS concretiza a Assistência Social como dever do Estado e direito dos que dela demandam, forjando um grande ciclo virtuoso de proteção social àqueles que por motivos inerentes ao sistema o qual se vive ou da própria condição humana, não se inserem nessa sociedade de forma emancipada, consciente e autônoma permitindo a eles e elas a condição de serem cidadãos e cidadãs.

Os serviços, programas, projetos serão ofertados de acordo com os níveis de proteção correspondente as demandas específicas de cada usuário. A proteção social no SUAS consiste no conjunto de cuidados, atividades, atenções, benefícios para a redução das iniqüidades sociais e prevenção das "vicissitudes sociais" (PNAS, 2004 p. 90) oriundas dessas, garantindo a dignidade humana. Tendo a família como matriz de suas ações. 
A proteção social do SUAS se divide de acordo com sua complexidade: básica, especial de média complexidade e especial de alta complexidade. A proteção social básica é destinada às pessoas que se encontram em situação de vulnerabilidade social decorrente da pobreza, o não acesso aos serviços públicos fundamentais ou algum tipo de privação (PNAS, 2004). Desse modo, a proteção social básica possui um caráter preventivo das situações de risco, promovendo e desenvolvendo as potencialidades e aquisições. Um programa a ser destacado da proteção social básica é o PAIF (Programa de Atenção Integral à Família), esse programa tem ocasionado consideráveis impactos na melhoria das condições de vida das famílias usuárias, ele é pactuado pelas três esferas de governo, ou seja, Municipal, Estadual e Federal (PNAS, 2004). Os benefícios eventuais que possuem o papel de cobrir necessidades temporárias como nascituro e o funeral também são disponibilizados pela proteção social básica. O centro de referência onde os serviços programas, projetos e benefícios de proteção social básica são disponibilizados para os usuários são os CRAS's. Estes são unidades públicas estatais de base territorial que devem estar disponibilizados em áreas de vulnerabilidade social com a capacidade de atender até 1000 famílias por ano.

A proteção social especial de média e alta complexidade remedia a situação de cidadãos que estão em risco social, ou seja, além das precariedades sociais que vivenciam como pobreza, miséria, desigualdade social, possuem agravantes nessas condições estabelecidas: o trabalho infantil, violências, abuso sexual, maus tratos físicos e psíquicos, uso de drogas, o cumprimento medidas sócio-educativas e situação de rua. Como o eixo para os atendimentos do SUAS é a matricialidade sócio-familiar, tendo a família como instituição em transformação, os sujeitos que são atendidos nesse nível de proteção possuem esses vínculos sócio-afetivos enfraquecidos atacados ou completamente violados nesse sentido, a proteção social especial intervém intentando restabelecer esses vínculos familiares e comunitários. A proteção especial de média complexidade se aplica àqueles (as) onde os direitos sociais foram violados, mas os vínculos familiares e comunitários ainda se mantém. Já os serviços, os programas e projetos de proteção com alta complexidade necessitam de toda uma estrutura física, como os CREAS (Centros de Referência Especializados de Assistência Social), pois, por questões do total rompimento familiar e comunitário, o (a) sujeito (a) por razão de risco preeminente devem ser retirados (as) de suas localidades e alocados (as) em estruturas estatais com proteção integral e cobertura de profissionais especializados. 
A proteção social básica e especial de média e alta complexidade configurada pelo SUAS, como tecnologia, representou um grande passo para se implementar com eficiência os serviços, os programas, os projetos e os benefícios socioassistenciais com efetividade para concretização dos direitos de proteção social aos sujeitos (as) subalternizados (as) da sociedade, mas além dessa tecnologia o SUAS como um sistema inovador, de cariz não contributivo e universal a todos (as) aqueles (as) que necessitem implementa uma nova institucionalidade de gestão referenciada na Constituição Federal/88, a descentralização e a participação nas políticas de seguridade social.

O SUAS está respaldado na Constituição/88 e no art. 6 da LOAS, 1993 que define que as atividades de Assistência Social:

"Devem ser organizadas em um sistema descentralizado e participativo, constituído pelas entidades e organizações de Assistência Social, articulando meios esforços e recursos, e por um conjunto de instâncias deliberativas, compostos pelos diversos setores envolvidos na área" (LOAS, 1993, art. 6).

A descentralização modifica a lógica em que a Assistência Social era concebida anteriormente, ainda na época da LBA, por exemplo, onde todos os serviços, programas projetos e benefícios eram centralizados em um poder e comando único, onde os critérios e definições de programas eram elaborados distante da realidade a qual iria ser efetivada. A forma centralizada, como num efeito piramidal concentrava as ações, competências e responsabilidades apenas em uma esfera, na federal, e as demais estâncias estaduais e municipais apenas executavam o que era verticalmente decidido. As decisões, quando chegavam à realidade vivida pelos usuários da assistência social nos Estados e Municípios, chegavam totalmente inadequadas, caducas às demandas dos sujeitos de cada localidade do território brasileiro. Desse modo, a descentralização do poder aliada a intensa participação, principalmente, dos usuários a quem a política se destina é mais um fator central que o SUAS operacionalizou de modo a melhorar a qualidade e eficiência dos serviços, programas, projetos e benefícios da política pública de Assistência Social. Entretanto é bom lembrar que a centralização e descentralização não são processos que a existência de uma anula a da outra, mas elas devem ser complementares, pois conferir Municípios e Estados de autonomia não significa conduzi-los ao isolamento e a total independência da esfera federal (BRASIL, 2008).

O SUAS seguindo as definições da Constituição Federal desenvolve o processo de descentralização entre as esferas de governo tornando os Municípios autônomos e 
independentes no plano político-institucional, não se limitando à reorganização estatal, mas, valorizando o poder local e a participação popular como base na prática democrática reconquistada após a ditadura militar (BRASIL, 2008). Isso significa recompor a base federativa por meio do redesenho institucional do Sistema de proteção social e da municipalização dos serviços sócio-assistenciais básicos (BRASIL, 2008).

A descentralização da política a partir do empoderamento Municipal e Estadual é um avanço para a efetivação do SUAS enquanto política que garante direitos sociais, pois ela permite melhor eficiência à população usuária local, pois o território e todas as suas peculiaridades são tomadas como referência para aplicação dos recursos destinados ao problemas específicos de cada região.

A atenção da Assistência Social, via o SUAS, volta-se para problemas coletivos e sócioterritoriais superando intervenções setorizadas e particularizadas que é orientada a ação universalizada sobre as lógicas "intersetoriais, matricial e de abordagem integral" (BRASIL, 2008, p. 23) assim, a territorialização torna-se elemento inerente à política de Assistência Social congregando o engajamento do poder local com a participação dos usuários e lideranças populares elaborando, planejando a gestão da assistência social a partir da realidade estabelecida de seus moradores, consolidando-a de forma mais distributiva e equânime (BRASIL, 2008) muito embora, a descentralização da Assistência Social, concordando com o período democrático vivenciado seja um amplo avanço dessa política enquanto pública o que significa envolvimento dos atores da Sociedade Civil e do Estado na sua elaboração, planejamento e execução, esse processo de municipalização deu-se em muitos municípios como uma transferência de poder de uma esfera para outra, mantendo-se ainda centralizado e autoritário, ou seja, municipalizar resultou para muitos "prefeiturizar" (p. 25) para muitos governantes que não acreditam da possibilidade e capacidade do poder local em interferir na gestão pública (BRASIL, 2008).

Os mecanismos descentralizadores de gestão, desse modo, acabam por servir a interesses puramente políticos que se apropriam da participação da Sociedade Civil como forma de legitimar o poder instituído e viabilizar o acesso a transferência de recursos federais (BRASIL, 2008), nisso o município como esfera política mais próxima dos cidadãos, ressalta com mais clareza o problema das práticas de cooptação política que se faz mais direta e reproduz, assim, modelos conservadores de "mandonismos 
políticos” (p. 26), o que, por sua vez, enfraquece os espaços coletivos como os conselhos e fóruns (BRASIL, 2008).

A municipalização da Assistência Social deu responsabilidades aos municípios quanto à gestão dessa política pública. Dentro dessa lógica de gestão os municípios podem ser habilitados em três níveis diferentes quanto a sua capacidade de gerir os serviços, programas, projetos e benefícios sócio-assistencias. Os níveis de gestão para os municípios podem ser: inicial, básica ou plena. $\mathrm{O}$ requisito fundamental para se ter a existência de qualquer tipo de gestão seja ela inicial, básica ou plena, é que o município tenha, funcionando, o Conselho Municipal de Assistência Social, Fundo Municipal destinado às ações da Assistência Social, com recursos próprios alocados, e um Plano de Assistência Social Municipal que responda as demandas locais, a partir de estudos e diagnósticos sócioterritoriais da realidade local. Esse é o critério primordial para que se tenha uma gestão a nível municipal de Assistência Social independente do nível em que estejam. Essa lógica do SUAS satisfaz o que está definido pela LOAS no seu art. 30 e que por sua vez segue aos preceitos Constitucionais.

$\mathrm{O}$ art. 30 da LOAS coloca como condição elementar para o repasse dos recursos de co-financiamento aos Municípios, Distrito Federal e Estados, o funcionamento do Conselho Municipal de Assistência Social, de composição paritária entre governo e sociedade civil. A resolução CNAS n 237 de 2009 define como Sociedade Civil em seu art. 11: os representantes dos usuários ou de organização dos usuários de Assistência Social; entidades e organizações de Assistência Social; e entidades de trabalhadores do setor. Os representantes governamentais são indicados pelo poder executivo local e devem, de alguma forma, estar ligados às políticas sociais, como Assistência Social, Saúde, Educação, Trabalho e Emprego, Fazenda ou outras políticas existentes. A eleição dos representantes da sociedade civil deve ser acompanhada pelo Ministério Público $^{14}$

Os Conselhos Municipais de Assistência Social como partícipe da gestão dessa política pública representa uma nova institucionalidade dentro da elaboração, planejamento e execução dessa política social, porquanto ao responder aos anseios democráticos, garantindo a participação não só consultiva, mas também deliberativa de todos (as) os (as) interessados (as) na sua implementação e execução traz resultados mais satisfatórios, pois terá um retorno que atenda as perspectivas de um maior número 
de pessoas. Dessa forma, os conselhos, apesar das cooptações políticas, dos coronelismos, das concepções ultrapassadas e conservadoras de Assistência Social, ainda largamente presentes em vários municípios brasileiros, que por muitas vezes reforça o paternalismo, a benesse e o primeirodamismo, não são complemento ou algo supérfluo ou ainda secundário. O conselho inserido no contexto da gestão passa a ser central e básico para a efetivação dessa política social de forma eficiente e garantidora de direitos.

Os conselhos devem ser instituídos pelo município mediante lei específica, na qual vai estabelecer sua composição de forma paritária, juntamente com o conjunto de suas atribuições e suas competências ${ }^{15}$. Eles devem ser vinculados à estrutura do órgão da administração pública responsável por gerir a Assistência Social no município ${ }^{16}$. É importante que todos os conselheiros participem de treinamento voltado ao controle social, conhecendo, para isso, a legislação que rege os serviços, benefícios, e programas de Assistência Social devendo manter-se informados a respeito do custo real dos serviços e programas de Assistência Social, dos indicadores socioeconômicos da população demandante dos serviços e participação ativa nas conferências e fóruns de Assistência Social ${ }^{17}$.

Os Conselhos Municipais de Assistência Social (CMAS) devem realizar junto à gestão local da respectiva política o acompanhamento das ações de outros agentes sejam eles gestores, outros conselheiros ou pessoas relacionadas à política, em um processo contínuo e constante; aprovar quando algo é submetido ao conselho como, o Plano de Ação e o Demonstrativo Sintético Financeiro ${ }^{18}$; o conselho deve assessorar quando

\author{
15 Idem. \\ 16 Ibidem. \\ 17 Cartilha SUAS (Sistema Único de Assistência Social). Implicações do SUAS e da Gestão \\ descentralizada na atuação dos Conselhos de Assistência Social. vol. 2, abril 2006.
}

18 O Plano de Ação é uma ferramenta de planejamento das ações da política de Assistência Social, os quais à união co-financia recursos destinados à assistência social. O Plano de Ação é um instrumento inserido no sistema virtual SUASWEB que tem por objetivo uma melhor qualidade na gestão dos recursos empregados nos serviços de Proteção Social Básica e Especial, assim como prediz o SUAS. Esse Plano representa uma previsão de onde e como serão alocados os recursos co-financiados, tendo por finalidade uma melhor qualidade dos serviços prestados pela assistência social nos diversos municípios brasileiros. Ele contém informações referentes aos órgãos federativos, órgãos gestores da assistência social, do Fundo Municipal de Assistência Social, informações do conselho, sobre a previsão de atendimento físico, previsão de financiamento, sobre o resumo executivo, comentários do gestor, e por último o parecer do conselho municipal aprovando ou indeferindo o referido Plano. Os Planos de Ação são acompanhados, atualmente, pelo Departamento de Gestão do SUAS (DGSUAS), do Ministério do 
outros necessitem de informações pertinentes as suas funções; deve elaborar algo sobre algum assunto em questão, tendo posicionamento claro. É necessário que ele seja normatizado possuindo regras claras do seu funcionamento para que suas ações sejam clarificadas e precisas; e por último ele deve ser propositivo a partir de uma construção coletiva ${ }^{19}$ pode-se perceber que no contexto de descentralização e participação instituído pela Constituição Federal de 1988, a gestão municipal concatenada ao controle democrático, realizado pelos conselhos, estabelece uma nova era para as políticas de proteção social inserindo um contrapeso à questão social a favor dos (as) trabalhadores (as) que apesar de representarem a ampla maioria da população brasileira, ficam subordinados ao capital monopolista internacional.

A divisão da gestão municipal de Assistência Social em níveis definido pelo SUAS em inicial, básica e plena especifica melhor a situação na qual o Município se encontra e o suporte que ele tem para gerir essa política social. Como já foi dito o requisito mínimo para que o município esteja habilitado ao menos na gestão inicial é que ele tenha funcionando o conselho municipal, o fundo com recursos próprios alocados e um plano local de Assistência Social. Na gestão básica, além das exigências que a inicial define, ele precisa ter um CRAS (Centro de Referência de Assistência Social) para prestar os serviços, programas, projetos e benefícios próprios da proteção social básica com capacidade de atender de acordo com o porte ${ }^{20}$ do município. Ele precisa fazer,

Desenvolvimento Social e Combate à Fome (MDS), por meio de uma coordenação específica; a Coordenação Geral de Regulação de Gestão Intergovernamental (CGRGI). Ela acompanha o preenchimento dos respectivos Planos concedendo orientações. O preenchimento deste está relacionado a um prazo pactuado na CIT (Comissão Intergestores Tripartite) espaço de criação de consensos e pactuações entre a esfera Federal, Estadual e Municipal, a ser encaminhados para deliberação da CNAS (Conselho Nacional de Assistência Social).

O que foi dito do Plano de Ação pode ser aplicado ao Demonstrativo Sintético Financeiro, entretanto, ele está relacionado à prestação de contas dos Municípios dos recursos disponibilizados pelo Governo Federal do ano que se passou. (www.mds.gov.br, acesso em abril 2009)

19 Cartilha SUAS (Sistema Único de Assistência Social). Implicações do SUAS e da Gestão descentralizada na atuação dos Conselhos de Assistência Social. vol. 2, abril 2006.

20 Pequeno porte 1: municípios até 20.000 habitantes. Esses municípios devem ter um CRAS para até 2500 famílias referenciadas;

Pequeno porte 2: municípios que tenham entre 20.001 a 50.000 habitantes. Esses municípios devem ter no mínimo um CRAS para atender até 3.500 famílias referenciadas;

Médio porte: são municípios que tenham entre 50.001 a 100.000 habitantes. Esses municípios devem ter no mínimo dois CRAS para atender até 5.000 famílias referenciadas; 
também, a realização de diagnósticos de áreas de risco e maior vulnerabilidade social. Por último, o Centro deve manter uma secretaria executiva no conselho de Assistência Social, isso significa especificamente o conselho ter um suporte técnico mínimo para viabilizar sua atuação (BRASIL, 2008).

Na gestão plena os pré-requisitos que a gestão inicial e básica exige são ampliados, é importante a presença de um sistema municipal de monitoramento e avaliação; ter a capacidade de atuar na proteção social especial de alta complexidade, aplicando todos os serviços, programas, projetos e benefícios pertinentes a essa proteção; contar com gestor do fundo municipal e ter uma política de recursos humanos com carreira para os servidores públicos (BRASIL, 2008).

Quanto às responsabilidades municipais por nível de gestão, uma que merece destaque, pois representa uma novidade graças ao advento das Novas Tecnologias de Informação e Comunicação (NTIC's) e perpassa por todos os níveis de gestão seja ela Inicial, Básica ou Plena, é a responsabilidade de todas às gestões municiarem, ou melhor, alimentarem com dados a Rede SUAS ${ }^{21}$ (BRASIL, 2008). Os dados disponibilizados na rede virtual possibilitam uma maior velocidade, agilidade ao acesso às informações estratégicas o que viabiliza o processo de decisão para a gestão com melhor eficiência, além do que permite o controle democrático.

A Rede SUAS é um sistema de informação próprio e específico que moderniza a administração na área da Assistência Social, estabelece mecanismos eficazes para o controle democrático e para tomada de decisão de todos os tipos (Tapajós \& Rodrigues, 2007). A Rede SUAS foi criada para centralizar volumes de dados administrativos alimentados, inclusive, pela gestão municipal ${ }^{22}$, em seus diferentes níveis, como responsabilidade, para gerar um repositório, por meio do sistema, viabilizando a geração de informações estratégicas para posterior recuperação (Rodrigues, 2007).

Grande porte: são municípios que tenham entre 100.001 a 900.000 habitantes. Esses municípios devem ter no mínimo quatro CRAS para atender até 5.000 famílias referenciadas;

Metrópoles: possuem mais de 900.000 habitantes. Elas precisam ter no mínimo 8 CRAS para atender até 5.000 famílias referenciadas( PNAS, 2004. NOB/SUAS p. 100).

21 A Rede SUAS abrange essa nova modalidade de gestão, ela é um sistema de informação que tem como meta responder as novas necessidades de informação e comunicação no âmbito do SUAS.

22 A partir de agora ao se falar em gestão está implícito as atribuições não somente do órgão ente gestor, mas, também, as competências dos conselhos e dos fundos inerentes à ela. 
A política de Assistência Social e as demais políticas assistenciais de transferência de renda, de governo, que o MDS administra, e é responsável a nível Federal por sua execução, gera um grande volume de informações que a utilização de ferramentas tecnológicas para o devido trato dessa informação complexa tornou-se imprescindível (Rodrigues, 2007).

A necessidade de lidar com essas informações geradas pela política que contempla técnicos, trabalhadores, gestores, conselheiros e usuários requer uma estruturação formal de atividade de gestão que dê apoio e atenda às diversas demandas por informações estratégicas.

Nesse sentido um Comitê Gestor de Tecnologia da Informação foi criado para elaborar uma Política de Tecnologia e Informação ${ }^{23}$ do MDS que contemplasse todos os objetivos e propósitos dos atores envolvidos com essa nova lógica de gestão.

A Rede SUAS e seus aplicativos inseridos nesse contexto de tecnologia e informação do MDS permite uma gestão inovadora dos serviços, programas, projetos e benefícios socioassistenciais no Brasil, visto que esse sistema de informação abarca todas as áreas que dizem respeito à gestão, ao financiamento e ao controle democrático da política,“ dando suporte aos seus novos dispositivos e procedimentos (Albuquerque \& Crus, 2007, p.19)',

Um dos pontos relevantes que podem ser considerados do SUAS e da sua respectiva Rede tecnológica e informacional é a questão da transferência dos recursos cofinanciados da União para estados, municípios e Distrito Federal, que desde sua implantação tem atendido à lógica descentralizada político-administrativa definida pela LOAS (1993) de forma ágil, regular e transparente favorecendo aos entes gestores, seus respectivos conselhos e trabalhadores da Assistência Social (Albuquerque \& Crus, 2007).

O SUASWEB, um dos aplicativos da Rede SUAS, onde estão inseridos o Plano de Ação e o Demonstrativo sintético financeiro, ele permite a fiscalização das ações e a obrigatoriedade tanto do acompanhamento como do planejamento estadual e municipal como da execução físico financeira da prestação de contas (Albuquerque \& Crus, 2007).

23 “A Política de Tecnologia de Informação do MDS deverá permitir direcionar as ações e guiar processos decisórios de modo que seja possível alinhar, de forma efetiva, a informação e o conhecimento com os objetivos do MDS” (Rede SUAS: gestão e sistema de informação para o SUAS, 2007, p. 28). 
Tomando o SUASWEB como um aplicativo de gestão informacional pode-se destacar o trabalho dos conselhos municipais cujos municípios estão habilitados em algum nível de gestão. As atividades do conselho são fundamentais para o repasse do co-financiamento dos recursos federais destinados aos serviços, programas, projetos e benefícios socioassistenciais, pois a ele cabe a aprovação ou indeferimento, após reunião registrada em ata, entre os conselheiros, dos Planos de Ação e Demonstrativo dos referentes anos, emitindo um parecer via SUASWEB, após análise destes.

Esse parecer de deliberação do conselho, lançado via SUASWEB, além de ser um pré-requisito para o repasse dos recursos co-financiados fundo a fundo deve servir como uma ferramenta de aprimoramento da gestão local, pois neste parecer devem ser lançados elementos fundamentais dados pelos conselheiros após análise do Plano de Ação e o Demonstrativo.

Os conselheiros, por meio desses pareceres via SUASWEB, precisam ofertar sua contribuição e crítica a respeito dos recursos alocados para o provimento dos serviços, programas, projetos e benefícios socioassistenciais co-financiados em conjunto entre a União, o Estado e o município responsável por sua execução. Neste sentido, pode-se perceber que o controle democrático, por meio dos conselhos, utilizando-se das NTIC's, passa a ser central para a implementação do SUAS com eficiência, eficácia e efetividade nas suas ações. Entretanto, os pareceres dos conselhos trazem informações insuficientes, quando não, só a mensagem: "esse conselho aprova esse Plano de Ação ou esse conselho aprova esse Demonstrativo" ${ }^{24}$. Desta forma, depreende-se que, existem contradições informacionais no fluxo de alimentação do sistema, pois o abastecimento dos dados, com informações pertinentes ao parecer, via SUASWEB, por parte de uma grande parte dos conselheiros à Rede SUAS, é irrisória. Isto se torna uma lacuna entre os enlaces, circuitos e fluxos que o sistema engendra não aproveitando toda a sua potencialidade ético-política e técno-operacional.

\footnotetext{
${ }^{24}$ Dado retirado do SUASWEB, Plano de Ação 2008 de Demonstrativo Sintético Financeiro 2007
} 


\section{Capítulo 2 - Os Conselhos de Assistência Social como um espaço público e democrático para direção e gestão do SUAS.}

\subsection{A participação como um ponto central dos conselhos gestores.}

A Rede SUAS permite a democratização da informação estratégica possibilitando a participação dos atores da sociedade civil na formulação, execução e avaliação da política de Assistência Social, forjando, assim, um espaço plural de esfera pública por meio das redes socioinformacionais, concretizando os preceitos da constituição cidadã.

A redemocratização do país e o surgimento de uma nova Constituição Federal, em 1988, resultado das reivindicações dos movimentos sociais e dos anseios de participação sociopolítico da sociedade, agregaram-se e reconheceram-se direitos sociais, que inclusive foram repudiados pela ala conservadora da sociedade.

A Constituição Federal de 1988, respondendo aos anseios democráticos, viabilizou bases para a construção de um novo pacto federativo como a descentralização de responsabilidades para os níveis estaduais e municipais, dando, também, maior saldo de recursos para eles. As políticas sociais como saúde, educação e assistência social foram municipalizadas com o advento do controle democrático pelos respectivos conselhos, isso estabelece uma nova institucionalidade do que tange a gestão de políticas públicas, pois os conselhos devem ser paritários, com o mesmo número de representantes escolhidos pela sociedade civil juntamente com os representantes do poder público. Essa participação da sociedade civil na construção e implementação de políticas juntamente com os entes governamentais estabelece uma nova condução para as políticas sociais, permitindo políticas cidadãs, pois a participação sociopolítica permite o controle destas políticas por parte dos usuários, viabilizando um atendimento das reais necessidades dos segmentos destinatários dessas políticas, principalmente da assistência social, que se deu historicamente difusa, fragmentada, sem perspectivas do atendimento de um direito social e sim da boa vontade, daqueles que a executam. 
A questão da participação da sociedade civil na gestão e no controle das políticas sociais representa as lutas da sociedade por acesso aos direitos sociais e de cidadania que reivindica melhores condições de vida pelo acesso aos benefícios da produzidos socialmente (Gohn, 2001).

Segundo Gohn (2001), a participação pode ser analisada segundo três níveis básicos, o nível conceptual, o político e o da prática social. O primeiro nível é referente ao paradigma teórico que o orienta; o segundo é relacionado ao processo de democratização. Esse nível pode ser usado como um discurso mistificador em busca de uma coesão social de forma que se tenha como regular e normatizar a sociedade por meio de políticas sociais de controle democrático; o terceiro nível está relacionado ao processo social referente às ações concretas por meio de lutas de movimento e organizações para realizar algum objetivo.

Em explicitação do nível conceptual Gohn (2001) explica que existem diversas formas de se entender participação, algumas inclusive, de acordo com elas são consideradas clássicas. São elas a liberal, a autoritária, a revolucionária e a democrática. Para Gohn (2001), essas interpretações não são monolíticas, elas geram outras interpretações.

$\mathrm{Na}$ concepção liberal a questão da participação é vista na forma de fortalecimento da sociedade civil, não para que esta participe do Estado ou sociedade política, mais sim para que esta se una contra as interferências do Estado no seu espaço. A leitura liberal visa fortalecer a democracia representativa, melhorando a qualidade da democracia representativa dentro dos marcos das relações capitalistas. Deste modo, nessa concepção todos os indivíduos são iguais e a participação seria o instrumento para a satisfação das necessidades. Logo, as barreiras burocráticas para essa participação devem ser eliminadas.

A participação corporativa é derivada da concepção liberal, pois ela é vista como um envolvimento espontâneo dos indivíduos, mas não em prol de um interesse particular, mas sim de um espírito coletivo em concordância com determinada ordem social que, de acordo com Gohn (2001), cria algo superior chamado bem comum. Nessa concepção o processo participativo é articulado com a existência das organizações na sociedade. Assim sendo, o funcionamento das instituições vão depender das pessoas que as tiverem controlando. 
A participação comunitária concebe o fortalecimento da sociedade civil em termos de integração de forma que está participe dos órgãos deliberativos, administrativos e representativos do Estado. Dessa forma, os grupos organizados da sociedade civil devem participar no interior dos aparelhos do poder estatal, até que as esferas do público e privado possam se unir. Ambas as concepções estão pautadas, segundo com Gohn (2001), no paradigma liberal, pois entendem a participação como movimento espontâneo do indivíduo, onde as questões de classe, etnias, gênero etc. não são colocadas em questão.

A forma de participação autoritária se dá por meio de políticas públicas que visam à integração e o controle social da sociedade e da política. Nessa forma, as políticas, no caso, as sociais são impostas de cima para baixo, tecnocraticamente, não visando à resolução dos problemas e sim amenizar os efeitos, trazendo certa coesão social.

$\mathrm{Na}$ forma democrática a soberania popular é o seu principio regulador, nessa concepção a participação é concebida tanto na sociedade civil quanto no plano institucional. Essa forma se opõe a concepção do corporativismo e coloca uma clara demarcação entre sociedade civil e o sistema político. O sistema representativo deve ser, via eleição, o critério máximo de organização dos indivíduos. Nessa concepção defende-se o ideal liberal da competição no interior da sociedade civil defendendo que no interior do Estado as hierarquias devem ser respeitadas.

No modo revolucionário, a participação se constitui em coletivos organizados que lutam contra as relações de dominação e pela divisão do poder político.

A concepção democrático-radical é uma junção da concepção democrática, juntamente com a concepção revolucionária. Nessa leitura objetiva-se fortalecer a sociedade civil para a construção de caminhos que apontem para uma nova realidade social, sem injustiças, exclusões, desigualdades, discriminações e etc.. O pluralismo é a marca dessa concepção, neste caso a participação está intrínseca ao tema da cidadania. A participação tem caráter plural e deve se criar uma cultura de dividir as responsabilidades na construção coletiva de um processo. Desta forma os indivíduos não são tratados isoladamente, nem membros de uma determinada classe social, e sim de forma coletiva, onde todos são cidadãos participam de forma plural.

Assim sendo de acordo com as variadas formas conceptuais de leitura e aplicação teórico-prático e político de participação, entende-se, nesse trabalho, que a 
concepção democrático-radical é a que mais se aproxima ao conceito de participação para os conselhos gestores de Assistência Social, ou a que deve ser mais usual para nortear as ações dos respectivos conselheiros nas suas ações, porque ela é que mais se identifica com o modelo de gestão definido e regulamentado pela LOAS, 1993 e proposto pelo SUAS, embora a concepção democrático-radical não veja os sujeitos inseridos em uma determinada classe social, o que diferente da Política de Assistência Social sabe-se que seus usuários ou demandantes são advindos da "classe que vive do trabalho" (Antunes, 1995 apud Raichelis, 2000). Assim, a Assistência Social é uma política universal que tem o objetivo de atender àqueles e aquelas que necessitem de seus serviços, programas, projetos e benefícios de forma que fiquem assegurados (as) das incontigências provocadas pelo capitalismo monopolista, na sua forma mais acirrada, e das fragilidades humanas.

A Assistência Social reforça deste modo, a proteção social para garantir a cidadania dos seus usuários devendo, assim, se utilizar desses conselhos que possuem caráter não só consultivo, mas principalmente deliberativo para concretizar direitos sociais. Para isso, esses conselhos devem ter como objetivo dos seus trabalhos, uma nova sociedade, ou seja, uma sociedade que supere o modo e modelo atual de produção e reprodução social, construindo novos caminhos que possibilitem a superação da sociedade capitalista com todas as suas iniqüidades sociais, assim, como também, a construção de uma cultura de inclusão social, respeitando as diferenças, os limites e as potencialidades de cada um (a) ou grupo social existente, numa perspectiva plural, para isso, o uso de tecnologias de informação e comunicação, como a Rede SUAS, por exemplo, se faz necessária nos dias atuais, pois pode publicizar e fazer circular de forma, rápida, ágil e eficiente a informação compreendendo um "processo crítico de comunicação pública" (Raichelis, 2000, p.34).

Voltando a questão da participação de acordo com Gohn (2001) ela está diretamente relacionada com o funcionamento dos conselhos gestores que, por sua vez, traz a idéia de esfera pública. A esfera pública está no centro dos debates sobre governança local segundo ela esse conceito é híbrido relacionando elementos de governo local com os de poder local.

Iniciado por Tocqueville, Thomas Jefferson e Stuart Mill, os estudos sobre governo local possuem uma longa tradição (Gohn, 2001). De acordo com Souza \& Blumm (1999) apud Gohn (2001), as teorias sobre governo local podem ser de categoria 
normativa. Essa categoria percorreu três fases e teve como defensores, na primeira fase, os seguidores da tradição de Stuart Mill. Eles incentivavam a participação política em oposição ao governo centralizado argumentando que as instituições locais realizariam a distribuição mais eficiente dos recursos. Na segunda fase, os reformadores do pósguerra, defendiam um governo local autônomo, pois tinham no governo local uma instância virtuosa, para a expansão do Estado de Bem-Estar Social. A terceira fase condiz que o governo local tem melhores condições para alocar recursos de acordo com as necessidades locais, pois está mais perto da comunidade.

Nas três linhas sobre o governo local, na perspectiva de Gohn (2001), intenta-se aumentar os níveis de participação democrática dos cidadãos, ao mesmo passo que intentam aumentar a eficiência do aparelho burocrático estatal.

O conceito de poder local é mais abrangente que o de governo local e, no Brasil, vários estudos apontam que ele adentra no interior do governo local e interfere nas políticas públicas locais (Daniel, 1994 apud Gohn, 2001). O poder local inclui o poder econômico, político e social das famílias, assim como o poder carismático de líderes regionais e locais.

A partir da década de 1990 as sedes urbanas dos municípios, no que se refere ao centro político-administrativo do governo municipal, passou a ser visto de um lado como poder local, por outro lado, esse poder, passou a ser visto como uma nova forma de participação e organização popular como dinamizador de mudanças sociais. Desta forma, o poder local passou a ser entendido como uma dimensão de gestão político administrativo e não como mera sede das elites. Neste sentido, Gohn (2001) coloca que o empoderamento da comunidade como o resultado da participação popular deu-se em conseqüência da redefinição de poder local para sinônimo de força social organizada de participação popular.

Retomando o conceito de governança local pode-se dizer, de acordo com Gohn (2001), que este se refere a um sistema de governo em que a inserção de novos atores sociais é essencial a partir do envolvimento de um conjunto de organizações públicas e privadas. Assim sendo, a governança local que compreende o debate sobre esfera pública, está no âmbito do universo de parcerias e é referente à gestão compartilhada entre os variados atores e agentes da sociedade civil e política.

Neste sentido, a esfera pública, de acordo com o conceito de Habermas apud Gohn (2001): 
"A esfera pública tem um papel fundamental na reconstrução da teoria democrática ao introduzir uma concepção participativa, discursiva, criando espaço para a generalização da ação social para o reconhecimento das diferenças e para a ampliação da forma do político". (Gohn, Maria da Glória, 2001, p. 41).

Por outro lado, o conceito de Habermas restringe a participação dos novos atores apenas como influência nas decisões governamentais e não com um caráter de sujeitos deliberativos, ou seja, com poder desses atores de decidirem os rumos políticoadministrativos das políticas sociais.

$\mathrm{Na}$ dimensão de esfera pública entra o conceito de democracia deliberativa que segundo Gohn (2001), deve ser um sistema que unifica a democracia direta com a democracia representativa, ela é referente aos mecanismos de representação política nos quais os indivíduos enquanto cidadãos políticos ativos constroem consensos para a geração elaboração de políticas públicas.

Dentro desse escopo teórico acerca do surgimento e orientação das políticas sociais, no caso mais especifico a política de Assistência Social, inclui-se um novo paradigma de gestão dessa política pública que se utiliza de tecnologias de informação e comunicação. Pode-se destacar essa nova forma de concepção de gestão e condução dessa política como um modelo que desfaz as associações históricas de ajuda, assistencialismo, paternalismo, populismo, tutela e caridade que outrora estavam arraigadas ou até mesmo confundidas com essa determinada política. Assim o controle democrático por meio dos conselhos municipais atende aos preceitos constitucionais ocupando um papel central no processo de execução dessa política tornando-se assim um espaço de esfera pública.

\subsection{Os conselhos municipais de Assistência Social como esfera pública.}

Os conselhos de Assistência Social são referenciados na esfera pública, ou seja, um espaço onde a sociedade civil, representada pelos trabalhadores do setor, as entidades prestadora dos serviços sócio-assistencias e os usuários dessa política, juntamente com a sociedade política representada pelo Estado e os órgãos governamentais possam construir consensos, pactuações e deliberações onde todos (as) os (as) envolvidos (as) possam, se sentirem contemplados (as) com as ações, previamente pactuadas e deliberadas, aplicadas. Para isso é necessário uma repolitização e fortalecimento da sociedade civil, para que dentro desses espaços públicos, ela possa 
representar seus interesses que nem sempre vão coincidir com os interesses do Estado responsável por executar os serviços, programas e projetos. Deste modo é preciso desconstruir no imaginário social e no senso comum que público seja sinônimo de estatal, o que não é verdade, pois público envolve interesses de todos (as) devendo assim ser decidido por todo (as). Assim as políticas de proteção social que no Brasil são representadas pela saúde, assistência social e previdência respondendo aos princípios constitucionais são colocadas no rol das políticas públicas sendo direito social do povo e dever do Estado em conduzi-la. Os conselhos gestores como os conselhos municipais de Assistência Social são estabelecidos de forma descentralizada e participativa insurgindo como um espaço central público para as decisões de interesses coletivos.

Os elementos constitutivos da esfera pública, onde a Constituição Federal de 1988 e a LOAS (1993) estabelece os conselhos municipais de Assistência Social, devem ser espaços caracterizados, de acordo com Raichelis (2000), pela visibilidade social, pelo controle democrático, pela representação dos interesses coletivos, democratização e cultura pública.

A visibilidade social deve ser entendida pela publicização e fidedignidade das informações que norteiam as decisões nos espaços públicos de representação garantindo assim a transparência das ações e discursos protagonizados; o controle democrático é exercido, por exemplo, quando os conselhos gestores a partir das informações estratégicas disponibilizadas pelo Estado ou sociedade política permitem que estes participem juntamente com a sociedade em geral "na formulação e revisão de regras que conduzem as negociações e a arbitragem sobre os interesses em jogo além do acompanhamento da implementação daquelas decisões, segundo critérios pactuados" (Raichelis, 2000, p. 43); a representação dos interesses coletivos implica no protagonismo dos sujeitos sociais que constituem papel de mediadores diante de questões políticas de demandas coletivas; a democratização corresponde a ampliação dos espaços tradicionais de representação por meio da desconcentração dos espaços de decisão política, incorporando desta forma novo atores e sujeitos sociais contribuindo para a construção de novos direitos. Este é um campo de conflitos e consensos, pois múltiplos interesses vão estar em jogo; por último é necessário o combate ao autoritarismo e a cultura privatista, pois sendo a política de Assistência Social, uma política pública incita a criação de uma nova cultura, uma cultura que tenha um caráter público. A cultura pública implica em dar visibilidade às demandas socialmente dadas 
ou produzidas por meio de um espaço que seja reconhecido por todos (as), para que assim pactuado por todos (as), se criem mediações sociopolíticas que busquem dar respostas públicas as demandas que são colocadas.

Os conselhos de Assistência Social como espaço de esfera pública devem ser apreendidos no contexto do Estado de Bem Estar Social ou Welfare State, onde o movimento do fundo público passa a sofrer inflexões da dinâmica de luta das classes sociais, que foi desvelada pela então questão $\operatorname{social}^{25}$, assim o deslocamento desse confronto passa da esfera privada ${ }^{26}$ para esfera pública a partir do momento que são criadas instituições sociais de bem estar, com o intuito de amenizar essas conflituosas relações, dando origem as políticas sociais.

Desta forma pode-se depreender que as políticas sociais se insurgem como públicas abrangendo a forma descentralizada com a atuação de conselhos locais deliberativos devido, principalmente, às transformações que o Estado capitalista vivenciou ao longo de suas tentativas de fazer sobreviver um sistema de crises. Assim a regulação keynesiana e a automatização fiscal do Estado interventor possibilitaram a ele o interferimento na economia e por meio do seu endividamento "atuar no processo de desigualdade social criado pelo mercado" por meio de instituições de promoção do bem estar social (Raichelis, 2000, p. 59).

Desta forma as políticas sociais com a atuação dos respectivos conselhos gestores como esfera pública é resultado da incapacidade da esfera privada em processar novas relações. Por isso quando a esfera privada incumbiu o Estado de determinadas responsabilidades e competências ele passa a ser uma "instância necessária da publicização", não se limitando somente a sua atuação é claro, para se garantir interesses que estão no âmbito privado (Oliveira, 1993, p. 138 apud Raichelis, 2000, p. $58)$.

Os conselhos como esfera pública devem compactar ao máximo a pluralidade de interesses que sua ampliação possibilitou para que suas ações sejam eficientes, entretanto segundo Habermas (1981) apud Raichelis (2000) isso se torna uma questão conflituosa, pois pela diversidade dos interesses torna-se difícil estabelecer um consenso entre as partes envolvidas, logo os conselhos municipais de Assistência Social e sua

\footnotetext{
25 Confronto existente entre os antagônicos e opostos interesses do trabalho versus o do capital.

26 A esfera privada é uma estância que corresponde ao doméstico, relações informais que varia conforme as relações sociais estabelecidas.
} 
rede de conselheiros (as) devem estar capacitados (as) para mediarem questões políticas complexas conforme o interesse de sua base de representados (as), construindo em conjunto com eles e elas mediações e relações que atendam os seus anseios. Para isso é necessário que estejam munidos independente de sua representação, com todas as informações estratégicas pertinentes à formulação, revisão e proposição de propostas para pactuação e deliberação que correspondam aos interesses coletivos. Por isso a Rede SUAS, sistema informacional do SUAS torna-se essencial para o exercício de suas atribuições, porquanto nela são disponibilizadas informações necessárias para a execução da política, a nível municipal, estadual e federal.

As atividades dos conselheiros num espaço de esfera pública tem o poder de diminuir a burocracia no interior das organizações trazendo mais agilidade nos processos de trabalho de formulação, implementação e avaliação da política pública. Esses novos processos de trabalho aliados à Rede SUAS permite que os conselhos submetam o MDS ao controle democrático permitindo níveis crescentes de autonomia e justiça social. Assim a Rede SUAS, para o exercício do controle democrático inserido na esfera pública pode ser visto como um processo de comunicação pública, típica da “publicidade politicamente ativa” de Habermas (1981) apud Raichelis (2000).

Os conselhos municipais de Assistência Social podem ser entendidos como uma "esfera social repolitizada" (Habermas, 1981 apud Raichelis, 2000) onde não mais existe o lugar do público e o lugar do privado divorciado e sim o seu casamento e interpenetração formando lócus estatizados da sociedade e espaços socializados do Estado, pois como espaços que são perpassados por antagonismos próprios do capitalismo, os sujeitos devem ter uma postura pró ativa conduzindo-os à defesa dos seus interesses.

Por isso a existência dos conselhos de Assistência Social pode representar a concretização de uma efetiva publicização da política que vai depender, principalmente, da forma como os conselheiros vão se colocar e se posicionar e no interesse do Estado em fomentar uma nova identidade para esses conselheiros. De forma que se consolide, assim, uma política pública que atenda direitos, pois os conselhos podem deslocar a Assistência Social do campo privado para a cena pública onde se "contemple a definição de regras e critérios públicos, mediadores entre o público estatal e o público privado" (Raichelis, 2000, p. 44). Para isso esses conselhos devem incorporar "mecanismos publicizadores" (p. 44) já referidos como a visibilidade social, controle 
democrático, representação dos interesses coletivos, democratização e cultura pública. Entretanto segundo Raichelis no campo da Assistência Social existem desafios a serem superados como, por exemplo, no caso da sociedade civil o trabalhador da Assistência Social, não se reconhece como tal, ou seja, não existe uma identidade fortalecida dos trabalhadores dessa política, os usuários, por sua vez, por sua própria condição histórica de subjugação e alienação têm uma tênue identidade política para conquista dos seus direitos, além de que os serviços sócio-assistencias são pouco reconhecidos por eles, dificultando a representação da identidade e dos interesses coletivos desse segmento da sociedade civil. Quanto às entidades assistenciais, são heterogêneas, sendo portadoras, quase sempre de um posicionamento desinteressado em favor dos usuários dos serviços sócio-assistencias os quais representam. $\mathrm{Na}$ área governamental segundo Raichelis os limites se encontram na falta de interlocução entre ela e a sociedade civil, o que dificulta no estabelecimento de consensos e alianças capazes de forjar decisões de caráter público.

Isso pode refletir de acordo com Vieira (1998) em conselhos formados para não funcionar, nesses casos os seus membros, ou parte deles, são escolhidos para falar o que se quer ouvir. Isto de acordo com ele é o que se pode denominar de "participação passiva", onde se estabelece uma relação de espelho, garantindo um espaço de participação para quem não participa de forma qualificada, crítica e propositiva.

Assim sendo para se estabelecer os conselhos de Assistência Social na esfera pública é necessário que se concretize uma "nova cultura política" (p.45) em um campo que historicamente nunca foi "publicizado" (p. 45) nem na estância dos atores diretamente envolvidos por ela, nem no plano de uma opinião crítica da sociedade. Por isso se faz necessário a constituição de consensos entre os atores sociais envolvidos, sejam eles governamentais ou da sociedade civil, em torno de uma direção ético-política pautado no âmbito dos direitos e da cidadania e não na tutela e no favor. A criação de valores pautados nessa nova dimensão ético-politica conduzirá e sustentará a Assistência Social em um projeto societário alternativo.

\subsection{Os conselhos municipais como controle democrático um eixo constitutivo da PNAS.}


O controle social pode ser visto por duas abordagens teórico-políticas, uma delas é compreendida quando o Estado controla a sociedade e outra quando a sociedade controla o Estado, neste caso, segundo Pereira (2005) o controle passa a ser democrático e é essa abordagem que se adota nesse trabalho. Este debate integra "o processo de fundação do Estado moderno" segundo Campos (2006).

Para Hobbes conforme Campos (2006), o Estado deve ser um instrumento de controle, pois para ele os homens são seres predadores em potencial, por isso o Estado nasce como resultante de um pacto aliado à força detendo, assim, o poder coercitivo velando esse contrato para que todos o cumpram. Nessa abordagem do Estado como um instrumento de controle da sociedade, Campos (2006) vê duas formas principais de controle social uma é relacionada aos controles externos e outra a controles internos. $\mathrm{O}$ controle externo está relacionado à repressão exercida por meio do poder coercitivo assegurando a manutenção da "ordem social" estabelecida. Desta forma esse tipo de controle adquire um modelo vertical de poder onde o Estado é visto como uma estância nobre. Por isso, o Estado torna-se um lugar próprio para se tomar decisões políticas, diferentemente do povo ou sociedade civil considerada um lócus iníquo e degenerado, ou seja, assim, ela deve ser um espaço para se exercer medidas coercitivas e de controle do Estado afim de que se mantenha uma determinada "ordem social". Já o controle interno segundo Campos (2006) é mais sutil, entretanto mais perigoso, pois é relacionado a uma determinada "socialização que naturaliza as desigualdades sociais e individuais, que justifica privilégios e consente discriminações, ou seja, são valores e crenças que constituem a formação sociocultural" (Campos, 2006), um exemplo disso é quando por meio de ideologias os usuários da Assistência Social, não usufruem dos seus serviços, programas, projetos e benefícios como um direito e sim como um favor o que incita uma relação de troca por parte desses com os executores dessas ações, tendendo a resguardar os interesses privados da elite em detrimento dos interesses coletivos da classe trabalhadora, que na sua essência são distintos.

O controle democrático, diferente do controle social, tem o potencial de superação dessa clássica, conservadora e autoritária concepção teórico-politica, onde poucos decidem os rumos e os objetivos das medidas e ações sociais ${ }^{27}$ para uma

27 Essas medidas e ações sociais são tomadas, nesse trabalho, no seu sentido lato sensu a qual significa que todas as ações feitas na e para a sociedade são sociais, independente se sua natureza for econômica, de cunho tecnológico, ambiental, agrário, espaciais, genético, físico-químico, astronômicas, 
esmagadora maioria. Assim o controle democrático tem o poder de inverter a lógica piramidal dentro das estruturas de poder, onde a base passa a influenciar e até mesmo contornar as decisões do topo.

Deste modo esse conceito é utilizado para designar as ações ou medidas da sociedade civil que controlam as ações estatais. Nessa perspectiva, o controle democrático, nas políticas sociais, mais especificamente no âmbito da política de Assistência Social no Brasil, de acordo com Campos (2006) possui um grande desafio a ser enfrentado que pode ser divido em duas dimensões: uma de natureza técnica e outra de natureza ético-política.

A dimensão política diz respeito à capacidade dos atores sociais em influenciarem na agenda governamental, para isto a sociedade civil via conselhos e organizações credenciadas devem possuir certas informações e orientações políticas que lhes permitam definir prioridades para influenciar nos compromissos governamentais. Porquanto a Assistência Social sendo de interesse público, cabe a todos (as) munidos (as) de informações estratégicas e pertinentes a sua execução, decidirem sobre seus rumos.

Do ponto de vista histórico, essas condições segundo Campos (2006) são inexistentes apesar das inovações na gestão pública, pois, ainda, a Assistência Social é considerada por muitas autoridades e pela sociedade civil em geral o espaço do não político, do voluntariado, do doméstico, ou seja, na esfera do privado e não do público.

Essa condição histórica gera não reconhecimento da política da Assistência Social como uma política garantidora de direitos prevista na Constituição, nos moldes da seguridade social o que enfraquece ainda mais o controle democrático (Campos, 2006). Como confirmação disto a partir da pesquisa de Boschetti (2003) apud Campos (2006) observa-se que $22 \%$ dos gestores estaduais e $34 \%$ dos gestores municipais de Assistência Social nunca encaminharam o relatório de gestão aos conselhos fiscalizadores ou fizeram isso de forma não regular. Entretanto sabe-se, hoje, que isso tem mudado com a obrigatoriedade desses relatórios como condição para os municípios

políticas sociais, militar, judiciais, informacional, comunicacional, relações internacionais etc. Posto que todas essas medidas e ações sejam criações ou reproduções exercidas por sujeitos (as) condicionados (as) historicamente por relações sociais vivenciadas por eles e elas. Por isso as decisões vão estar embebidas de social, não existindo neutralidade nessas ações, logo tudo é e vem do social, no que diz respeito ao que se produz e se reproduz nas sociedades humanas. 
serem ou ficarem habilitados em algum nível de gestão da Assistência Social, a partir do preenchimento do Demonstrativo Sintético de Execução Físico-Financeiro disponibilizado via SUASWEB da Rede SUAS.

Mas como superação dessa resultante histórica da apreensão, desenvolvimento e aplicação da Assistência Social, o controle democrático se mostra como um componente primordial para a conformação dessa política na esfera pública, cujo requisito central é a exigência de sujeitos coletivos dotados de autonomia e representatividade legítima (Campos, 2006 apud Raichelis, 2000).

Outra dimensão do controle democrático, segundo Campos (2006), é a dimensão técnica, que representa um domínio de conhecimento nas áreas de administração e contabilidade. Esta demanda segundo o autor é a demanda mais recorrente nas Conferências de Assistência Social. O autor aponta alguns problemas relacionados a essa demanda como a falta de um quadro profissional habilitado e politicamente independente do poder executivo; irregularidades nos relatórios contábeis elaborados pelo executivo aos conselhos; e a falta de qualificação dos próprios conselheiros para o exercício de suas atribuições.

No que diz respeito ao melhoramento das ações de controle democrático, é necessário que se produzam informações mais consistentes, precisas e qualificadas postas em circulação, em prol disso Campos (2006) aponta para o surgimento de um modelo de avaliação não só por vias quantitativas, mas também por vieses qualitativos. Desta forma, deve-se existir um modelo de avaliação que rompa com a lógica tradicional das ações difusas e não objetivadas, por meio de um modelo que permita um melhor planejamento e melhoramento das técnicas aplicadas possibilitando a retroalimentação via Rede SUAS, a partir do monitoramento e avaliação, onde na perspectiva do SUAS são dimensões integrantes do controle democrático.

No que diz respeito à dimensão ética, deve - se admitir que o controle democrático deva assumir antes de uma capacidade técnico-política, uma postura ética que vá além da pura eficácia administrativa, porquanto frente à subalternidade dos (as) usuários (as) decorrente da herança paternalista e autoritária, eles e elas acabam consentindo que outros e outras representem seus interesses, para isso que os conselhos devem garantir as falas e os discursos desses atores, por meio de sua participação ativa no processo de controle da gestão, os fazendo se sentirem parte e integrantes desse processo. Isso deve ser compromisso e se constituir em responsabilidade moral que 
nenhuma sociedade e governo sério devem abster (Campos, 2006 apud Pereira, 2001). Assim aliada à garantia da participação ativa, os conselhos devem assumir juntamente com os usuários o combate às iniqüidades sociais na perspectiva de construção de um futuro capaz de reduzir as desigualdades proporcionando justiça social.

Neste sentido, seguindo a Constituição/1988 e o art. 16 da LOAS, os conselhos de Assistência Social são estâncias deliberativas de caráter permanente de forma paritária entre o governo e a sociedade civil, passando a fazer parte do poder executivo da Assistência Social. Assim eles devem orientar, fiscalizar e formular para o planejamento das ações administrativas dessa política pública em conjunto com os seus respectivos órgãos gestores, ficando, deste modo, incumbidos de cumprir a $\operatorname{LOAS}^{28}$.

Os conselhos municipais e estaduais devem ser criados com o número definido de conselheiros titulares e suplentes, o período de cada mandato dos conselheiros ${ }^{29}$ e a sua estrutura, mediante lei específica dos respectivos estados e municípios, de acordo com a resolução CNAS $n^{\circ}$ 237/2006. Após a criação, os conselheiros necessitam elaborar um regimento interno contendo:

- Detalhamento de suas competências, de acordo com o que está definido na LOAS;

- Criação de comissões temáticas e grupos de trabalho temporários e permanentes;

- Detalhamento das atribuições da Secretaria Executiva;

- Definição do processo de escolha dos conselheiros;

- Definição da substituição de conselheiros e perda de mandato;

- Orientação de como serão publicadas as decisões do plenário;

- Indicação das condições que devem ser seguidas para alterar o regimento interno (Cartilha SUAS: orientação a cerca dos conselhos e do controle social da política pública de Assistência Social, vol. 1, p. 21).

Após aprovação do regimento interno, contendo especificamente as ações do conselho municipal e estadual de Assistência Social, ele deve ser aprovado pelo coletivo dos conselheiros em plenária ampliado.

Empossados os conselheiros e regimento interno aprovado, os representantes devem ter plenas condições para serem os legítimos defensores dos segmentos que representam. Os conselhos devem ser responsáveis pela convocação das Conferências

\footnotetext{
28 Cartilha SUAS: Orientações a cerca dos conselhos e do controle social da política pública, Vol.

1

29 A resolução CNAS n ${ }^{\circ} 237 / 2006$ no seu art. $5^{\circ}$ sugere que o mandato dos conselheiros deve ser de no mínimo dois anos, podendo ser reconduzido uma única vez por igual período.
} 
municipais ou estadual para que possam ser deliberadas questões pertinentes a gestão e a política na sua localidade.

Os conselheiros governamentais que são indicados pelos secretários da Assistência Social ou equivalentes são responsáveis por trazer informações claras e atualizadas sobre a diretriz que diga a posição do governo em pauta. Já os conselheiros da sociedade civil devem trazer contribuições dos segmentos que representam por meio dos debates a serem realizados nessas instâncias, em espaços como os fóruns, movimentos sociais e etc. Assim os conselheiros representantes da sociedade civil e governamentais devem compartilhar informações para que assim tomem em conjunto as deliberações.

A secretaria executiva dos conselhos assume um papel fundamental para o andamento dos seus respectivos trabalhos porquanto ela é responsável por transmitir informações úteis aos conselheiros da sociedade civil e governamentais em tempo hábil para o cumprimento de prazos a serem seguidos. Ela deve, também, registrar as reuniões dos conselhos em atas, mantendo a documentação atualizada; publicar as resoluções do conselho no diário oficial. As secretarias executivas dos conselhos, ainda, devem informar os conselheiros das reuniões, das pautas, e das comissões temáticas se houverem. E por último elas devem zelar os acervos produzidos pelo seu respectivo conselho.

A condução dos trabalhos dos conselhos municipais é um eixo constitutivo do SUAS e é fundamental para que a Assistência Social se dê de forma descentralizada e participativa para que o direito social seja garantido aos seus usuários, os emancipando socialmente. Para isso, os conselhos devem comparar, discutir e definir metas dos Planos de Assistência Social locais; analisar e dar o parecer do Plano e do orçamento; Acompanhar o processo de votação do Plano/Orçamento junto ao poder legislativo; acompanhar o acesso de votação das emendas orçamentárias, também junto ao poder legislativo; avaliar o plano e sua execução orçamentária; divulgar o Plano municipal de Assistência Social juntamente com a PNAS; recorrer ao ministério público em caso de irregularidades; em caso de irregularidades na execução orçamentária recorrer ao Tribunal de Contas da União.

No que corresponde ao uso da Rede SUAS pelos conselheiros de forma ativa seria o envio anualmente do Plano de Ação via aplicativo SUASWEB e enviar o parecer do Demonstrativo Sintético Anual da Execução Físico-Finaceira também via 
SUASWEB. Desta forma os conselhos podem e devem exercer o controle democrático para que seja garantida a ampliação do acesso, efetivação dos direitos sócio-assistencias e ampliação da participação. 


\section{Capítulo 3 - As Novas Tecnologias de Informação e Comunicação como um advento para o exercício dos Conselhos Municipais de Assistência Social.}

\subsection{As NTIC's no contexto da Revolução Informacional.}

A revolução informacional está intimamente relacionada com a modificação do modelo de produção baseado na máquina-ferramenta para o modelo pautado na automação. Esse novo estágio das forças produtivas materiais e humanas (Lojkine, 1995) desencadeado pela inserção das Novas Tecnologias da Informação e Comunicação no processo de desenvolvimento da produção, onde o trato da informação passa a ser o principal produto dessa interação, embora se dê numa sociedade capitalista, assim como foi a revolução industrial, esse estágio proporciona uma potencialidade distinta, a criação de uma sociedade pós-mercantil.

Deste modo a revolução informacional segundo Lojkine (1995) é uma revolução tecnológica de conjunto que sucede a revolução industrial a qual segundo ele está em vias de terminar. A era industrial, onde as forças produtivas materiais estavam centradas na maquina-ferramenta não se esgotando nesse instrumento de trabalho, mas também nas relações sociais nas quais elas estavam inseridas, sendo sua principal representante, tinha como principais características a especialização do trabalho coletivo com a fundamental oposição entre trabalho manual e trabalho intelectual; estandartização; e reprodução rígida.

Com o advento do avanço tecnológico como a microeletrônica, os microcomputadores, as redes telemáticas e comunicacionais na sua respectiva interação e sua posterior inserção nas forças produtivas de um capital pós-fordista taylorista, engendrava um novo período social uma nova revolução que possui a potencialidade de ultrapassar a antiga divisão que opõem homens e mulheres desde que existem sociedades de classes, a divisão entre os (as) que produzem e os que dirigem a sociedade, a divisão dos que podem pensar e daqueles e aquelas que são excluídos (as) dessa ação que também é resultado de uma ação produtiva.

Assim como a revolução industrial não se reduz à invenção da máquinaferramenta a revolução informacional não se reduz à automação da produção (Lojkine, 
1995). Entretanto nesse "complexo sistêmico" (p. 73) pode-se identificar três principais características: a polifuncionalidade dos instrumentos de produção, onde as novas tecnologias estão acopladas; a flexibilidade que se refere ao variados usos possíveis das máquinas informacionais; e por último a descentralização das estruturas da rede. Desta forma a oposição posta entre revolução industrial e revolução informacional no que diz respeito às forças produtivas materiais é o contínuo e rígido funcionamento das máquinas da revolução industrial contra a auto-regulação dos sistemas flexíveis na automação.

A polivalência existente nesse novo processo é uma característica própria gestada no âmago da revolução informacional da mesma forma que a especialização se remete a revolução industrial. Essa polivalência, ou melhor, a polifuncionalidade citada por Lojkine implica numa grande máquina universal que compreende um grande conjunto de diferentes atividades, onde os trabalhadores não mais ficam separados por divisão de trabalho. A partir da máquina flexível que comporta um grande número de variadas atividades distintas exige dos trabalhadores uma cooperação independente dos níveis do processo de produção que são encarregados o que ocasiona uma polifuncionalidade das forças produtivas humanas.

Essa mutação ocorrida na esfera sócio-técnica, onde as forças de produção estão no cerne dessa nova reestruturação social questionam a divisão do trabalho por meio da “especialização flexível” (Lojkine, 1995, p.13). Acabando a separação entre os que decidem e os que executam, insurgirá na empresa uma recomposição de funções (Lojkine, 1995).

Quanto à questão dos poderes políticos locais a revolução informacional proporcionará uma verdadeira descentralização ou desconcentração das burocracias centrais possibilitando aos governos locais mais autonomia em relação ao poder federal o que lhes dará condição de pequenos Estados.

Essa potencialidade atribuída à revolução informacional é definida, justamente pela mutação que as forças produtivas humanas e materiais vão sofrer por meio da inserção das tecnologias derivadas da microeletrônica conciliada com as redes telecomunicacionais, possibilitando a força produtiva material certa auto-suficiência, ou seja, em condições adversas, a máquina da automação vai ter um alto poder de adaptação e resolução de problemas sem a necessidade da intervenção humana. Essa inovação no setor de produção dará as forças produtivas humanas — principal 
intermediário entre o produto e a máquina — sendo assim, responsáveis pela: condução, manobra e manipulação da máquina, outras preocupações e objetivações de sua força produtiva intencional no processo produtivo. Com a liberação do cérebro humano dessas atividades ele fica livre para não mais executar e sim refletir sobre o processo de execução criando, melhorando e regulando as ações que primeiramente eram realizadas por eles (as) para que estas se tornem mais eficientes aos seus objetivos.

O maquinário da automação referente à revolução informacional vai absorver a função sensível-reflexiva que se objetiva na direção e vigilância da máquina outrora destinada a mulheres e homens e agora pertencem ao processos automatizados, deste modo a máquina pensa para suas atividades.

Neste sentido a informática vai cumprir esse papel de controle da produção material, onde por meio dela as condições subjetivas do homem estão sistematizadas e automatizadas para a objetivação dos processos de atenção e de condutas humanas (Lojkine, 1995). Assim as NTICs onde a revolução informacional está ancorada coloca uma nova questão a do controle social de volumosas massas de informação que a interação da informática e das telecomunicações fazem circular.

A informação promissora que a revolução informacional dimensiona não é uma informação estandardizada ou estandardizável, mas sim uma informação de cunho reflexivo, intuitivo e criador. Logo a revolução informacional não é somente a estocagem e a circulação de informações difundidas por diferentes "mass média" (p.109), ela deve envolver acima de tudo a criação, o acesso e a intervenção sobre as informações estratégicas sejam elas de natureza social, científica política, econômica ou ética no geral até as informações sobre a informação que regulam o sentido das informações sejam elas particulares, operatórias que cobrem a vida diária (Lojkine, 1995).

O ser humano integrado a maquina nesse novo modelo de produção social, onde Lojkine (1995) nos chama atenção para o surgimento de uma nova revolução igual ou superior àquela comandada pela máquina-ferramenta, ou seja, a revolução informacional, para Castells (2003) apud Medeiros (2007) esse desenvolvimento possibilita a formação de uma sociedade em rede cuja fonte de produtividade desta está baseada na produção de conhecimentos no processamento da informação e comunicação dos símbolos. 
Se para Lojkine o advento das tecnologias de informação e comunicação representaram o aparecimento da revolução informacional com a potencialidade de se concretizar uma sociedade pós-mercantil, para Castells (2003) apud Medeiros (2007) essas tecnologias e a reestruturação do capitalismo representaram a estruturação de uma nova forma de sociedade, a sociedade em redes. Para se entender de que sociedade se trata é necessário entender qual o significado de rede para Castells. O conceito de rede apreendido por ele é:

"As redes constituem a nova morfologia das nossas sociedades, e a difusão da lógica da rede modifica substancialmente a operação e os produtos nos processos de produção, experiência, poder e cultura. Enquanto que a forma de rede de organização social existiu noutros tempos e noutros espaços, o paradigma da nova tecnologia de informação fornece o material de base para sua expansão hegemônica por toda a estrutura social. Mais, defendo que esta lógica da rede induz uma determinação social de um nível mais elevado do que aquela dos interesses sociais específicos expressos através das redes: o poder dos fluxos assume supremacia sobre os fluxos de poder. (...) As redes são estruturas abertas, com o potencial de se expandirem sem limites, integrando novos nós desde que sejam capazes de comunicar dentro da rede, nomeadamente desde que partilhem os mesmos códigos de comunicação (por exemplo, valores ou objetivos de desempenho). Uma estrutura social com base na rede é um sistema altamente dinâmico e aberto, susceptível de inovar sem ameaçar o seu próprio equilíbrio" (Medeiros, 2007, p. 23-24 apud Castells apud Stoer, 2003, p.1199).

Os avanços revolucionários da microeletrônica, a microbiologia - que diz respeito aos avanços relacionados à genética - e a energia nuclear abrem novos caminhos para o ser humano sobre os seus conhecimentos a cerca do ambiente em que vive e dos entes com quem interagem trazendo um novo desenvolvimento para a humanidade (Shaff, 1995). Esses progressos tecnológicos possibilitam uma sociedade em redes conceituada por Castells (2003).

As NTICs dinamizam e possibilitam um mundo em rede, onde a informação ganha o papel de destaque proporcionando a era dos serviços sem que se perca o papel da produção o que traz impactos na esfera social. Esses impactos estão relacionados à potencialidade do surgimento de uma sociedade da informação onde as capacidades intelectuais do ser humano são ampliadas e inclusive substituída por essas tecnologias (Shaff, 1995). 
O acesso à sociedade da informação caberá a tão somente segundo Castells (2003) a capacidade do Estado, de cada sociedade, ou das organizações para a criação e o monitoramento da informação para que essa sociedade seja viável em termos de participação e acesso.

As NTICs representadas pela interface de grandes áreas como a informática, a microeletrônica e as telecomunicações são os pilares da sociedade da informação Castells (2003) e suas contribuições para o seu respectivo desenvolvimento são: a informática que permite o tratamento dos dados pertinentes à informação; a microeletrônica que atribui a essas informações sons, imagens e numeralização dos dados; e por último as telecomunicações que entendidas como as "redes" permite a transferência das informações colocadas em comunicação como um "serviço" (Medeiros, 2007 apud Castells, 2003).

A funcionalidade dessas tecnologias apreendidas por Castells se dá pela alta capacidade de agir sobre a informação; a penetrabilidade dos impactos sociais que elas podem ocasionar; a compreensão da lógica de redes; flexibilidade quanto ao seu uso; integração de sistemas específicos em um sistema universal (Medeiros, 2007 apud Castells, 2003). Desta forma a informação gerada, tratada, transferida e armazenada deve se dá de forma que ela seja útil para a sociedade em geral (Medeiros, 2007).

A difusão e o impacto das NTICs que possuem o efeito de penetração em todos os campos referente às atividades humanas vai alcançar as organizações em geral, inclusive o próprio Estado. Desta forma a informação deve ser tomada de forma crítica por essas organizações e não apenas absorvida de forma imparcial (Tapajós, 2003).

Assim sendo a informação gerada por determinada instituição deve de fato produzir conhecimentos no sentido de informar a sociedade e não desinformá-la (Tapajós, 2003), ou seja, essa informação deve ser de fácil compreensão para todos (as) aqueles (as) interessados (as) no seu conteúdo.

As novas demandas da sociedade frente a essa sociedade da informação incube ao Estado um papel estratégico para sedimentação dessas novidades (Tapajós, 2003) de forma que ele possa conduzir essa inovações aos interesses de todas e todos, ou seja, dos interesses coletivos. As políticas de proteção social onde o Estado tem primazia por sua execução seria um lócus privilegiado para apropriação das Novas Tecnologias, entretanto, antes da implementação do SUAS e da sua respectiva rede informacional, a Rede SUAS, o conjunto tecnológico da seguridade social que diz respeito a proteção e 
promoção social ainda não estava voltado para a democratização dessas políticas (Tapajós, 2003).

Nesse sentido Tapajós (2003) defende no campo da seguridade social a categoria da "Informação Social" onde ela se configura como uma fonte estratégica para a criação de novos espaços públicos assegurando o caráter democrático que essas políticas foram concebidas por meio da Constituição de 1988. Por isso as potencialidades permitidas pelas Novas Tecnologias associadas às políticas de Seguridade Social se fazem essenciais para a democratização e controle democrático dessas políticas de direito social (Medeiros, 2007 apud Tapajós, 2003).

\subsection{Rede SUAS: a produção, unificação, armazenamento e circulação da informação estratégica como uma nova forma de gestão descentralizada e participativa.}

A gestão da informação no SUAS, contemplando as deliberações das Conferências Nacionais de Assistência Social, tem um papel primordial e estratégico o de viabilizar e consolidar um sistema descentralizado e participativo nos formato de um sistema único (Tapajós, 2007).

A Rede SUAS, sistema de informação, é acionada por um aparato tecnológico de ponta com grande capacidade e extensão o que possibilita o processamento de dados advindos de variadas fontes transformando esses dados em informação e conhecimento úteis a gestão sendo assim uma ferramenta estratégica para o processo de decisão juntamente com as ações do controle público e o democrático (Tapajós, 2007). Esse sistema informatizado concentra, armazena e distribui informações referentes à gestão, ao controle democrático e ao financiamento da política. Essa rede segundo Tapajós (2007) estabelece uma interdependência entre os elementos ou subsistema que a constituem, pois interativamente conselheiros (as), gestores (as), técnicos (as), usuários (as) e a sociedade em geral agem sobre os dados que são inseridos e disponibilizados virtualmente. Assim para se gerir a informação nesse sistema é preciso alterar a ação de quem produz, armazena, organiza e a classifica na esfera de gestão (Tapajós, 2007) para que ela se dê de forma qualificada e flexível ao contingente de informações disponibilizadas pelo universo de atores (as) sociais conectados (as) a rede. A alteração 
da ação requer um preciso e sistematizado trabalho com os dados produzidos para que as alternativas frente aos desafios e a realidade colocada sejam superados.

Assim sendo se faz necessário a relevância de um aporte tecnológico para dar suporte às informações geradas e criadas ultrapassando as experiências tecnológicas anteriores onde as informações eram centralizadas e a tecnologia disposta permitia um manejo por parte dos atores (as) envolvidos (as) (técnicos, conselheiros, usuários, gestores) apenas a nível operacional onde as decisões a cerca da objetivação do sistema dependia dos analistas e consultores de empresas privadas externas ao cotidiano das relações de produção do trabalho socioassistencial desenvolvido.

Modificando esse quadro a Rede SUAS é um sistema próprio para área de Assistência Social que comporta a grande parte das exigências dos objetivos consagrados por meio de uma luta histórica consolidada pela Política de Assistência Social no seu atual estágio (Tapajós, 2007). Assim a Rede SUAS é um sistema de informação que compreende as especificidades das ações de proteção social básica e especial de alta e média complexidade refletindo no seu sistema operacional a natureza e a gestão em cada ação considerando a gestão financeira e administrativa relevando seus aspectos éticos, "políticos técnicos e sociais" (Tapajós, 2007, p.74).

A Rede SUAS muda a conjuntura e a forma com que o Estado se apropriava dos aparelhos tecnológicos de forma tecnocrática e conservadora, até então, para a execução das políticas de proteção social, paralisando a força dos empreendimentos sociais a partir dos seguintes aspectos operacionais prejudiciais ao sistema almejado (Tapajós, 2007) descentralizado e participativo:

- "sistemas existentes sem mecanismos e possibilidades de cooperação, hospedados em instalações separadas e, em alguns casos, em plataformas incompatíveis;

- Fragmentação de dados dos programas sociais em bases de dados heterogêneas e sem rotinas automatizadas;

- Produção de informações por meio de planilhas eletrônicas preparadas manualmente e reconfiguradas conforme novas necessidades;

- Informações gerenciais para tomada de decisão obtidas a partir da consulta de sistemas informatizados, ambientados em instalações externas ao MDS;

- Fluxo de dados e informações dos programas da Assistência Social sem padronização gerenciamento central e sem a devida socialização com outras áreas-fim do MDS;

- Beneficiários e gestores envolvidos nos processos com interações precárias entre si e com outros órgãos do governo; 
- Impossibilidade de acompanhamento de execução e do alcance dos programas inexistindo uma base de dados de apoio para a ação de controle financeiro, monitoramento e avaliação. (Tapajós, 2007, p. 74).

Superando essas inconsistências para a implementação de uma nova forma de gerir a informação no âmbito da Assistência Social foram estabelecidas linhas diretivas resultado dos trabalhos decorrentes da I Oficina Nacional sobre Gestão da Informação em Assistência Social em novembro de 2005, onde a participação de municípios e estados foi essencial para a construção coletiva desse processo. Os três eixos que comportam as linhas diretivas podem ser:

- Apreensão e subordinação das inovações tecnológicas e informacionais às estratégias e os objetivos primordiais da PNAS/2004, utilizando a gestão da informação de forma que o trânsito da informação seja garantido em todos os níveis técnicos, gerenciais, gestão municipal ou estadual (atendendo as suas respectivas especificidades regionais) e usuários permitindo constantes alterações nos modelos institucionais de gestão por meio de sua atualização sistemática envolvendo as instâncias municipais, Distrito Federal, estaduais e federal em prol de uma maior aplicabilidade e eficiência da política atendendo a todos os envolvidos;

- Disponibilização por meio da Internet de informações necessárias ao funcionamento e andamento da gestão em todas as estâncias e níveis com garantia de acesso diferenciado entre eles;

- Transparência, consistência, confiabilidade dos dados e resultados produzidos de forma que eles sejam disponibilizados com uma linguagem compreensível para a população não deixando de garantir o resguardo das informações sigilosas instituídas legalmente em respeito ao princípio ético (Tapajós, 2007).

Seguindo esses eixos podem ser evidenciados os aplicativos da Rede SUAS que “dão suporte Gerencial e Apoio à Decisão" (BRASIL, 2008, vol.1, p.122). São eles o SUASWEB, o GeoSUAS, o InfoSUAS, o CadSUAS, o SigSUAS, o SICNASweb, o SISFAF, o SIAORC e por último o SISCON.

O SUASWEB é um ambiente virtual que contém informações fundamentais para a gestão de forma descentralizada e participativa com a possibilidade de controle democrático. Nele estão inseridos informações essenciais para a gestão como saldos, 
contas corrente, extrato de repasse de recursos federal co-financiados contendo ordem bancária, data do pagamento entre outros. Nele também estão dispostas informações referentes às informações cadastrais por município dos assegurados pelo Benefício de Prestação Continuada (BPC) e a freqüência mensal das crianças e adolescentes nas ações socioeducativas, como o jornada ampliada do Programa de Erradicação ao Trabalho Infantil (PETI).

O SUASWEB ainda comporta o Plano de Ação do co-financiamento federal e o Demonstrativo Sintético da Execução Físico Financeiro que é aberto para os municípios preencherem como condição de habilitação, desses, em algum nível de gestão e para os estados que estão responsáveis pela aplicação dos recursos dos municípios não habilitados. O Plano de Ação e o Demonstrativo devem ser preenchidos pelos gestores municipais ou estaduais e posteriormente, após o preenchimento, devem passar pela aprovação do seu respectivo conselho municipal ou estadual. É importante lembrar que gestores e conselheiros dispõem de senhas diferenciadas para acessar o respectivo sistema para executar, analisar e fiscalizar o que lhes compete. Só no ano de 2006 foram distribuídas 11.600 senhas para órgão ente gestor, conselhos, fundos, órgãos de controle, centros de pesquisa, consultores e outros órgãos (BRASIL, 2008, vol.1).

O GeoSUAS é um aplicativo da Rede SUAS aberto a consulta pública que possibilita a construção de indicadores sociais, econômicos e variáveis da política de Assistência Social. Por meio dele, pode ter as informações valiosas, a cerca da política nos estados e municípios, que se dão a partir da integração, processamento e transformação dos dados de cada território revelando, assim, suas respectivas particularidade e necessidades a cerca da Assistência Social em cada região, incluindo os municípios, por isso ele é um sistema de georeferenciamento que fundamenta a tomada de decisão para o processo de gestão da política. Percebe-se que esse sistema reforça a cultura pública da política ao permitir o acesso a toda população sobre os dados e informações georeferenciadas elaboradas (BRASIL, 2008, vol. 1).

O InfoSUAS ainda reforçando a cultura pública na Assistência Social é acessível a toda população brasileira, permitindo informações sobre a cobertura e o detalhamento dos valores repassados ao municípios divididos por eixos de proteção social e por tipo de intervenção contendo a identificação do ano, do município, estado ou região (BRASIL, 2008, vol.1). Ele reflete as operações do SUASWEB do SISFAF e SIARORC que são sistemas de gestão financeira (BRASIL, 2008, vol.1). Ele tem 
demonstrado ser uma ferramenta eficaz para o controle democrático porquanto ele permite o acesso às informações pertinentes as transações dos recursos que cofinanciam os serviços programas, projetos e benefícios sócio-assistencias (BRASIL, 2008, vol. 1).

O Aplicativo CadSUAS possui todas a informações cadastrais das prefeituras, órgão gestor, fundo e conselho municipal, possui, também o cadastro das entidades executoras de serviços sócio-assistencias que possuem ou demandam o registro e certificado no CNAS e por último possui as informações cadastrais de todos os trabalhadores da Assistência Social (BRASIL, 2008). As informações do Cadastro Nacional do SUAS também é disponibilizado para consulta por toda a sociedade (BRASIL, 2008, vol. 1).

O SigSUAS sistema de gestão do SUAS tem o objetivo de recuperar os dados detalhados de execução físico-financeira das transferências de estados e municípios para a rede executora do SUAS. Esses dados fundamentaram a emissão de relatórios anuais de gestão para a aprovação dos conselhos municipais de Assistência Social, CNAS e o MDS. Esse sistema permite um dialogo mais consistente entre os técnicos, serviços e gerencia de programas. Ele possui representações gráficas e está disposto na rede WWW (BRASIL, 2008, vol. 1).

O sistema que processa as operações especificas do CNAS é o SICNASweb, desta forma ele é o sistema de informação disponibilizado para o acompanhamento da tramitação dos processos e registros e certificação com a respectiva impressão dessas certidão para interessados (as) (BRASIL, 2008, vol. 1).

Os aplicativos da Rede SUAS que comportam os fluxos informacionais do Fundo Nacional de Assistência Social (FNAS) são: o SISFAF (Sistema de Transferência Fundo a Fundo) que agiliza os procedimentos de repasse dos recursos do fundo federal para os fundos municipais e estaduais sendo sua base de dados refletida no InfoSUAS o que permite visibilidade na transação dos recursos; O SIAORC (Sistema de Acompanhamento Orçamentário) que interage com o SISFAF e alimentado pelo SIAFI (Sistema Integrado de Administração Financeira do Governo Federal) é o sistema próprio para a gestão orçamentária dos recursos geridos pelo Fundo Nacional de Assistência Social. Após o tratamento dos dados referente à gestão dos recursos a nível federal no SIAORC, esses são atualizados no SISFAF e no SIAF (BRASIL, 2008, vol. 1). E por último o SISCON (Sistema de Gestão de Convênios) onde são controlados os 
projetos sócio-assistencias da proteção básica e especial acompanha-se, assim, todo o trâmite destes projetos desde sua habilitação, preenchimento dos planos de trabalho, formalização dos convênios até a prestação de contas (Brasil, 2008, vol.1).

Esses são os sistemas que compõem a Rede SUAS, pode-se constatar que eles apreendem as potencialidades que a "Revolução Informacional" oferece, posto que ao publicizar as informações, e facilitar o livre trânsito de informações estratégicas a técnicos, gestores, conselheiros, usuários, profissionais, agentes operacionais e a sociedade em geral, ou seja, a todos (as), a tomada de decisão se dá mais qualificada contemplando ao maior número de atores (as) envolvidos (as). Isso viabiliza a superação da clássica divisão entre os que decidem e os que executam, todos ficam responsáveis, dentro das suas competências, pela gestão do SUAS.

Assim a Rede SUAS é um sistema de informação inovador para a gestão da política de Assistência social, estabelecendo uma nova cultura para a área, com vistas a consolidar essa política como pública, garantindo o direito social daqueles que são assegurados por ela, por meio de novos padrões de agilidade e transparência.

\subsection{A contribuição da Rede SUAS para eficiência dos conselheiros municipais nas suas atribuições.}

A Rede SUAS é um sistema de informação que segue a lógica descentralizada com garantia à participação efetiva de todos (as) os (as) atores (as) envolvidos (as), logo é uma rede que se configura como uma estratégia de democratização das relações de poder resultando no acesso a bens e serviços públicos (Medeiros, 2007). Desta forma, é um meio informacional, onde os conselheiros municipais de Assistência Social têm acesso às informações pertinentes para a gestão do SUAS como financiamento, repasse dos recursos públicos que subsidiam os serviços, programas, projetos e serviços da Assistência Social, bem como permite a interação dos conselhos municipais lhes atribuindo uma postura informacional ativa e deliberativa sobre as ações implementadas pelos gestores com os recursos co-financiados, quando a eles cabem a emissão de um parecer, via SUASWEB, aprovando ou não o Plano de Ação e o Demonstrativo sintético de execução físico financeiro por exemplo.

A condição desse parecer implica na habilitação do seu município em algum nível de gestão da Assistência Social que pode ser inicial, básica ou plena. A Rede 
SUAS possibilitando o exercício informacional dos conselhos municipais e estaduais está em sintonia com os preceitos da Constituição e da LOAS, que são imperativas ao afirmarem que o controle democrático é um eixo componente e estruturante da gestão a nível municipal, estadual e federal para a execução eficaz dessa política como pública inserida no campo dos direitos.

Os aplicativos da Rede SUAS viabilizam um fluxo informacional interativo entre a União, o estado e o município de informações estratégicas que possibilitam o controle democrático da gestão dessa política condizente com as reais necessidades regionais e locais do município. Desta forma o conselho, instrumento democrático, institucionalizado como componente de gestão da Assistência Social de forma descentralizada e participativa possui deveres, atribuições e direitos para exercer um trabalho qualificado perante o controle dessa política, na direção de publicizar esse espaço garantindo um melhor acesso aos serviços, programas e projetos de qualidade aos usuários dessa política, visando à cidadania.

Deste modo a Rede SUAS tem um papel fundamental, pois ela moderniza as ações da área por meio de um aparato tecnológico, informacional e comunicacional que permite a integração, circulação, armazenamento de informações necessárias a todos e todos os atores (as) responsáveis pela gestão da políticas como os (as) conselheiros (as), por exemplo. Logo essa Rede se mostra como uma ferramenta fundamental para as atribuições dos conselheiros nas suas funções instituídas e respaldadas legalmente.

Por meio do Plano de Ação e do Demonstrativo sintético de execução físico financeiro dispostos no SUASWEB, na parte que diz respeito à execução física, os conselhos municipais podem exercer a orientação e controle do fundo municipal, estadual e federal dos recursos destinados pelo município para co-financiar os serviços, programas e projetos conforme o art. 30, II da LOAS, 1993. Desta forma o SUASWEB juntamente com o InfoSUAS são essenciais para a análise da proposta orçamentária dos recursos destinadas às ações finais de Assistência Social. Assim com base nas informações contidas no SUASWEB cabe aos conselhos municipais e estaduais aprovar o Plano de Ação e seu respectivo relatório de gestão, por meio da elaboração de um parecer, inserido na Rede, via SUASWEB, contendo informações que subsidiem seu posicionamento.

A consulta dos conselheiros ao GeoSUAS - que permite a construção de indicadores a partir do cruzamento de informações de todos os municípios sobre as 
variáveis socioeconômicas e programas mantidos pelo MDS - os conselhos podem fazer proposições a cerca da política municipal de assistência social baseados em informações georeferenciadas e geoprocessadas acompanhando e controlando posteriormente a execução desta política.

O SICNASweb é o sistema de informação do CNAS que possibilita o acompanhamento da tramitação dos processos de registro e certificação de entidades de natureza privada como sócio-assistencias. Assim ela dá aos conselheiros um meio de verificar como está o andamento desse processo na instância federal. Como o conselho municipal está mais próximo das entidades e organizações privadas que recebem o Certificado de Entidade Beneficente de Assistência Social ${ }^{30}$, ele pode fiscalizar se tudo está ocorrendo conforme os princípios e diretrizes estabelecidos pelo art. 4 da LOAS, no caso do descumprimento desses o conselho municipal pode propor ao CNAS o cancelamento desses registros dessas entidades e organizações, logo o SICNASweb torna-se uma ferramenta de consulta que deve ser observado pelos conselheiros municipais para a sua atuação qualificada.

O CadSUAS que também informam aos conselheiros a rede de entidades executoras de serviços socioassistenciais que possuem ou solicitam registro e certificados ou registro no CNAS, também permite que eles tenham um panorama geral dos atores pessoas físicas e jurídicas envolvidos com a execução e gestão da política como os dados cadastrais dos trabalhadores do SUAS em todo território nacional e os dados cadastrais das prefeituras, órgãos gestores, fundos e conselhos municipais. Essa rede de atores disponibilizada no CadSUAS permite aos conselheiros identificarem a rede socioassistencial que compõe a arquitetura de rede descentralizada do SUAS.

Os aplicativos da Rede SUAS como o SigSUAS, o SISFAF e o SIAORC junto com os Planos de Ação e Demonstrativos do SUASWEB permitem o controle e a gestão dos recursos públicos por meio das transações orçamentárias Fundo a Fundo juntamente com as devidas prestações de contas dos recursos aplicados para a efetivação das ações socioassistenciais.

Pode se depreender que se faz necessário o uso pelos conselheiros dessas Novas Tecnologias de Informação e Comunicação como a Rede SUAS por meio de sua arquitetura descentralizada para que eles possam contribuir significativamente como um

\footnotetext{
${ }^{30}$ Decreto 6.308/2007.
} 
instrumento de gestão democrático atendendo às necessidades sociais dos usuários dessa política.

\section{Capítulo 4 - O Perfil informacional dos Conselheiros Municipais de Assistência Social: contradições na implantação da Rede SUAS}

A análise do perfil informacional dos conselheiros municipais destacando as contradições na implantação da Rede SUAS teve por fundamento as macro categorias conectividade, acessibilidade e diretividade política cujas foram baseadas na crítica de Lojkine à rentabilidade capitalista (Souza, 2005). Este autor propõe o conceito de eficácia societal, ultrapassando o conceito da tradição de eficácia orientada pelo mercado.

A partir da categoria conectividade foi possível montar o perfil informacional das conexões da rede social dos conselheiros, no que tange o eixo controle social da PNAS. Permitindo, assim, a construção e caracterização da nodalidade dessas conexões, dos enlaces, circuitos e fluxos estabelecidos em suas relações.

A acessibilidade articula os três conceitos que constituem a rede, sendo eles os enlaces, os circuitos e os fluxos (Souza, 2005). Essa categoria viabiliza expor as contradições dos nós da rede social em questão no que tange a eficácia e eficiência das ações na área da Assistência Social estipuladas e parametradas pela LOAS, PNAS, NOBSUAS, Plano Decenal.

A diretividade política trata das diferentes direções e visões políticas que condicionam a comunicação entre os enlaces da rede social em questão (Souza, 2005). Ela avalia a eficácia do desempenho político no que diz respeito à questão dos fundamentos da gestão da informação, revelando, assim, as bases sobre as quais se fundamentam os conceitos informacionais das diferentes organizações "explicitando as contradições das falas e das práticas para que sejam questionadas do ponto de vista do quadro referencial teórico da Revolução Informacional" (Souza, 2005, p.37). Por meio da diretividade política pode-se apreender as tendências políticas da rede de conselhos municipais como um instrumento pré-requisito para a gestão ${ }^{31}$. Tomando essa categoria

\footnotetext{
${ }^{31}$ De acordo com o art. 30 da LOAS o funcionamento do conselho municipal, o fundo próprio com recursos alocados e a existência de um plano municipal de Assistência social são pré-requisitos de gestão.
} 
foi possível destacar um campo informacional composto por uma dimensão vetorial variante entre o conservadorismo político informacional dos conselheiros até o seu oposto, encontrado no outro pólo do campo, sendo definido como a tendência de superação das práticas informacionais conservadoras dos conselheiros municipais de Assistência Social. As práticas políticas informacionais que se encontram entre esses dois pólos, ficando no meio deles, foram denominadas como práticas políticoinformacionais de centro.

A pesquisa analisada pelas categorias teóricas da conectividade, acessibilidade e diretividade política e pelas subcategorias: enlaces, circuitos e fluxos viabilizou uma proposta de um esquema de conectores dos pontos da rede de Assistência Social. 


\section{Conectores da Rede Socioinformacional}
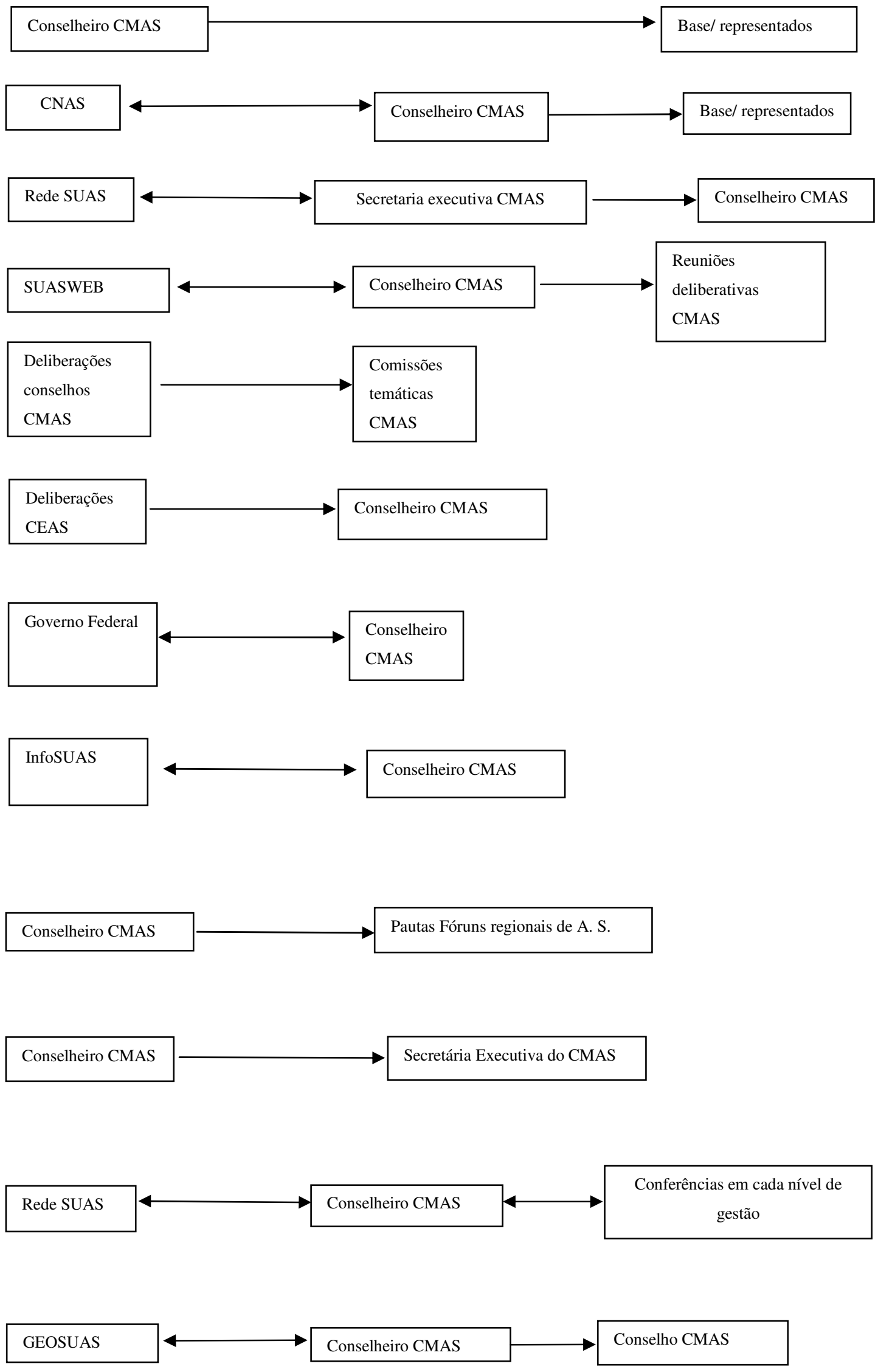


\subsection{Conectividade}

Gráfico 2- Grau de conectividade presencial entre a base e o conselheiro off-line

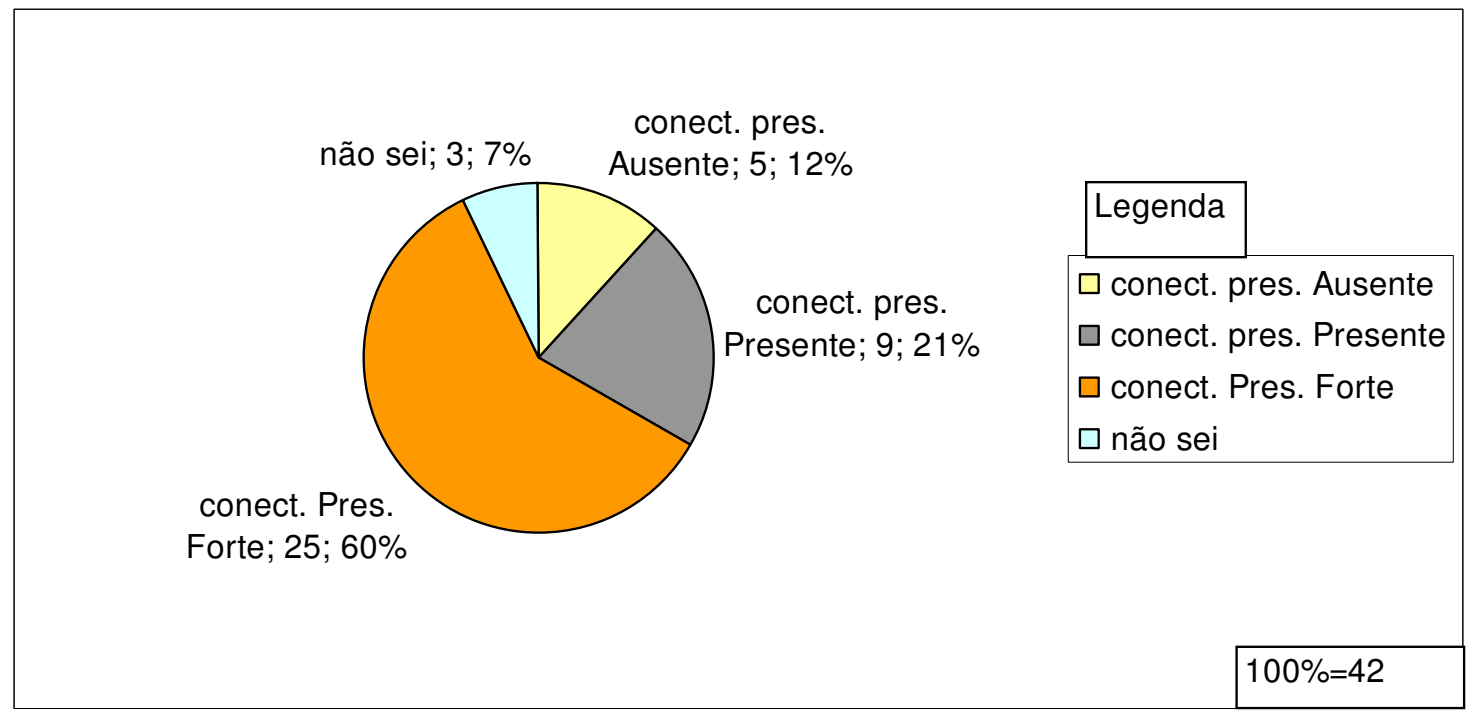

O grau de conectividade presencial entre os conselheiros e suas respectivas bases representa os encontros que os primeiros possuem com os segundo para o repasse de informações estratégicas, fomentando a participação deles nos conselhos como um espaço público e democrático de forma que a tomada de decisão contemple o máximo possível os anseios coletivos que a política de Assistência Social se propõe a suprir, referentes às necessidades sociais inerentes ao ser, como o convívio na sociedade de forma autônoma e cidadã. Dos 42 conselheiros municipais, equivalente a $11 \%$ do total da amostra, que responderam ao instrumental de pesquisa pode-se constatar que esses nós da rede - conselheiro e base - possuem um fluxo off-line (Ausência do intermédio da rede socioinformacional) alto, para repasse de informações do conselho à base, em torno de $60 \%$, ou seja, esses conselheiros se encontram com sua base de representados para repassar informações essenciais para se definir a condução da Assistência Social a nível local, ao mesmo tempo em que buscam, a partir desses encontros, proposições para serem levadas ao conselho municipal.

A conectividade presencial ausente representa aqueles conselheiros que não realizam esse tipo de encontro com sua base, resultando numa postura conservadora e anti-participativa o que vai contra a lógica do SUAS, entretanto, dentre o respondentes, a pesquisa demonstrou que $12 \%$ do total não realizam esse tipo de ação um número não tão alto, mas considerável. 
A conectividade presencial presente implica no número de conselheiros que realizam encontros presenciais com sua base, porém não fica garantido que esses encontros sejam para o repasse de informações estratégicas, ou deliberações dos conselhos.

A conectividade presencial presente forte representa a gama de conselheiros que organizam encontros presenciais para com sua base para repassar informações e decisões tomadas pelos conselhos e órgão gestores a cerca do controle democrático e gestão do SUAS no seu município ficando concatenada à lógica descentralizada e participativa. Neste sentido, $60 \%$ dos conselheiros municipais, mais da metade, procura fomentar a participação da comunidade nos conselhos municipais atendendo a lógica da gestão democrática e participativa do SUAS.

Gráfico 3- Grau de conectividade on line entre a base, conselheiro da secretaria executiva do CMAS, CNAS.

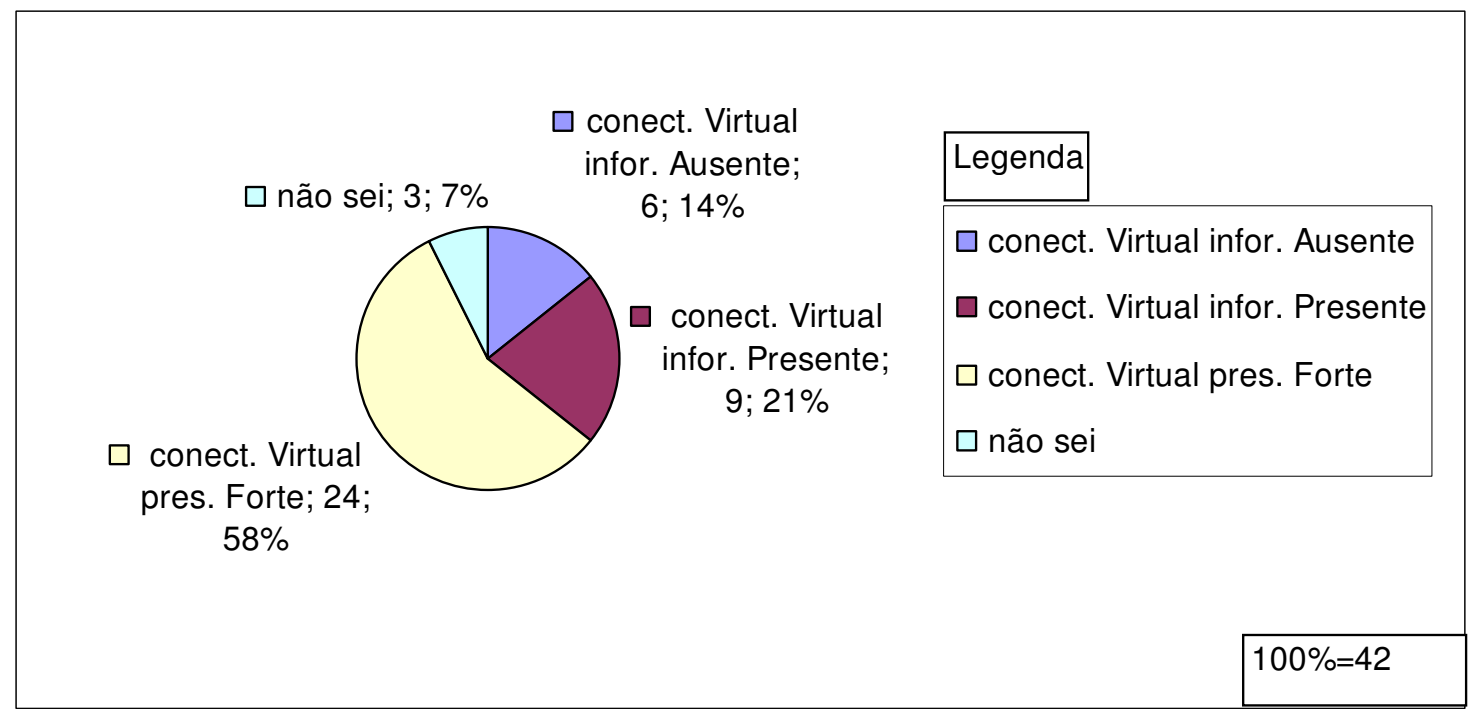

A conectividade virtual entre base, conselheiros da secretária executiva do CMAS e CNAS permite saber o grau de uso da internet pelos conselheiros para informar a base de representados sobre as deliberações, resoluções e demais ações do CNAS. Os dados mostram que existe um fluxo de informações estratégicas via a Rede socioinformacional entre o circuito base, secretaria executiva do CMAS e CNAS. Esse dado representa uma horizontalização de informações importantes pertinentes a uma gestão democrática que se apropria das potencialidades das NTIC's no contexto da revolução informacional. 
A conectividade virtual ausente representa aqueles conselheiros que não utilizam a internet para informar à sua base sobre as decisões, resoluções, ações do CNAS. A conectividade virtual presente se refere aqueles que se utilizam da internet para repassar informações, mas não precisamente as deliberações, resoluções e ações do CNAS, esse número deve ser considerado posto que $21 \%$ é uma porcentagem elevada quanto ao número de conselheiros da secretaria executiva do CMAS que necessariamente não mantém um fluxo de informações em prol da publicização e democratização da Política de Assistência Social, não aproveitando assim, as potencialidades da Revolução Informacional de superação, entre os que pensam e os que executam. A conectividade virtual presente forte é igual aos conselheiros que usam a internet para repassar informações, deliberações, resoluções e ações do CNAS, aproveitando as potencialidades que as NTICs proporcionam em beneficio das ações de publicização e democratização da informação. Ela condiz com a lógica de gestão do SUAS, descentralizada, democrática e participativa, desta forma mais da metade dos conselheiros municipais se mostram adeptos a essa nova realidade de gestão. 


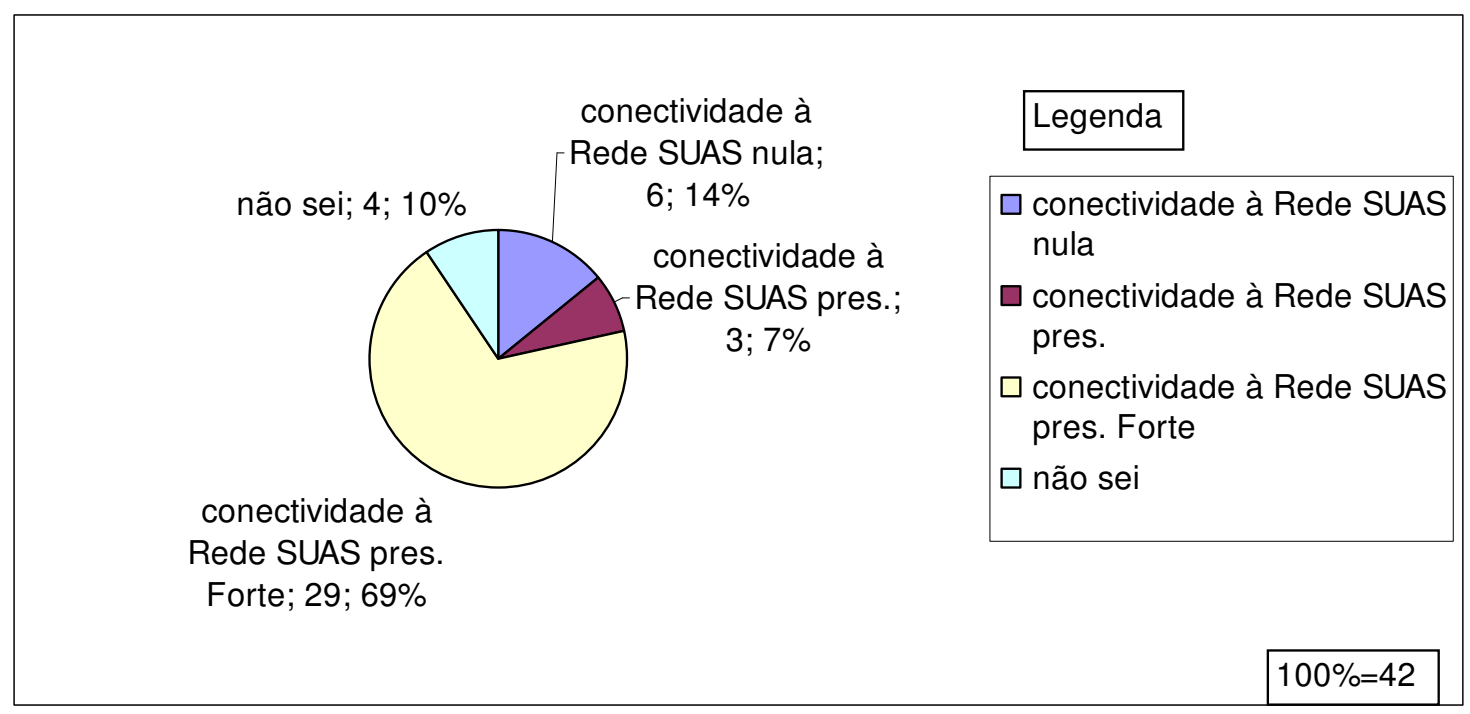

O grau de conectividade secretaria executiva do CMAS e conselheiros, onde a primeira repassa a senha de acesso à Rede SUAS para os segundo, permite saber como está essa relação para conexão virtual à essa Rede Informacional. A conectividade à Rede SUAS nula representa aqueles conselheiros que não tiveram a senha disponibilizada pela secretaria executiva do CMAS para acesso a Rede SUAS. Considerando o retorno da amostra muito pequeno, para se fazer qualquer afirmação mais contundente, pode-se observar que existe uma porcentagem bastante considerável de $14 \%$ dos conselheiros não estarem conectados a Rede SUAS, desta forma pode-se inferir que o circuito proposto secretaria executiva do conselho, conselheiros, e Rede SUAS é frágil o que dificulta ou até mesmo impossibilita o fluxo de informações necessárias para o controle democrático. A conexão a Rede SUAS presente é igual ao número de conselheiros que obtiveram a senha, mas não pela via secretaria executiva dos conselhos municipais, ou seja, elas foram obtidas por terceiros, como secretários de Assistência Social, técnicos MDS, conselheiros estaduais etc. Desta forma eles estão conectados a Rede SUAS mas não pela via convencional e sim por uma via paralela. A conectividade Rede SUAS forte é referente àqueles que obtiveram a senha de acesso para conexão via secretária executiva CMAS o que demonstra que um fluxo favorável para o controle democrático. 
Gráfico 5- Grau de relevância dada ao SUASWEB para tomada de decisão dos conselheiros

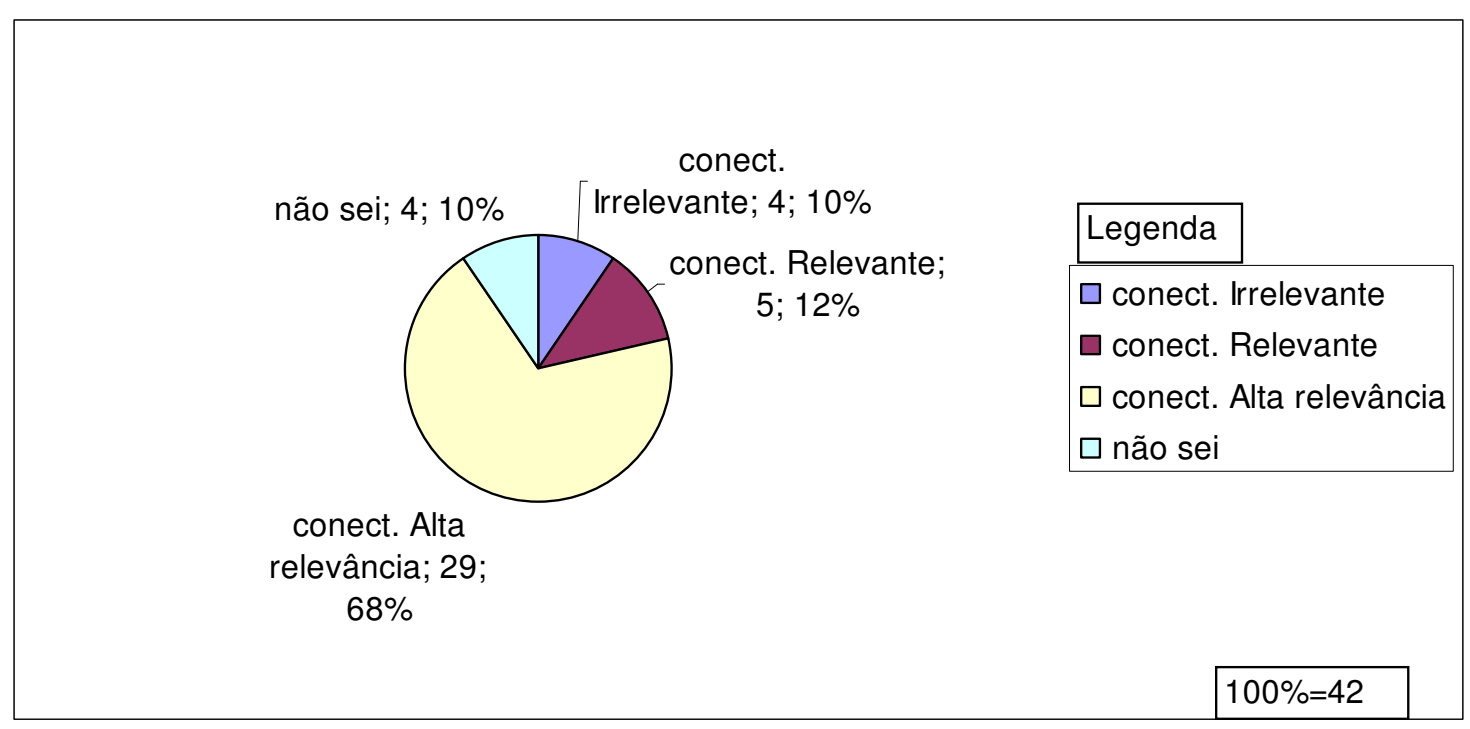

A conectividade de relevância do aplicativo SUASWEB para tomada de decisão dos conselheiros nas deliberações dos conselhos municipais permite saber a importância desse enlace para as ações decisivas dos CMAS. A conectividade de alta relevância se remete ao numero de conselheiros que consultam periodicamente o aplicativo SUASWEB antes da tomada de decisão nos conselhos municipais. Assim, pode ser constatado uma taxa favorável de $68 \%$ de conselheiros que acham essa rede socioinformacional necessária. Isso demonstra que as informações estratégicas disponibilizadas na Rede SUAS estão de fácil entendimento o que possibilita inferir que essa Rede está sendo pautando na via democrática de gestão. A conectividade irrelevante corresponde ao número de conselheiros que não se utilizam desse aplicativo, cujo contém informações de alta importância a respeito da gestão do SUAS no município, deste modo a porcentagem de $10 \%$ é um número relevante o que significa que essa Rede pode se tornar mais acessível e democrática e por outro lado é preciso estimular os conselheiros para o uso e apropriação dessa ferramenta por meio de mais capacitações voltadas para essa área. A conectividade relevante está associada ao número de conselheiros que concordam em parte nessa importância para qualificação dos seus votos nas deliberações do conselho. 


\subsection{Acessibilidade}

Gráfico 6- Grau de acessibilidade para a processualidade e conformação do enlace comissões temáticas e conselhos.

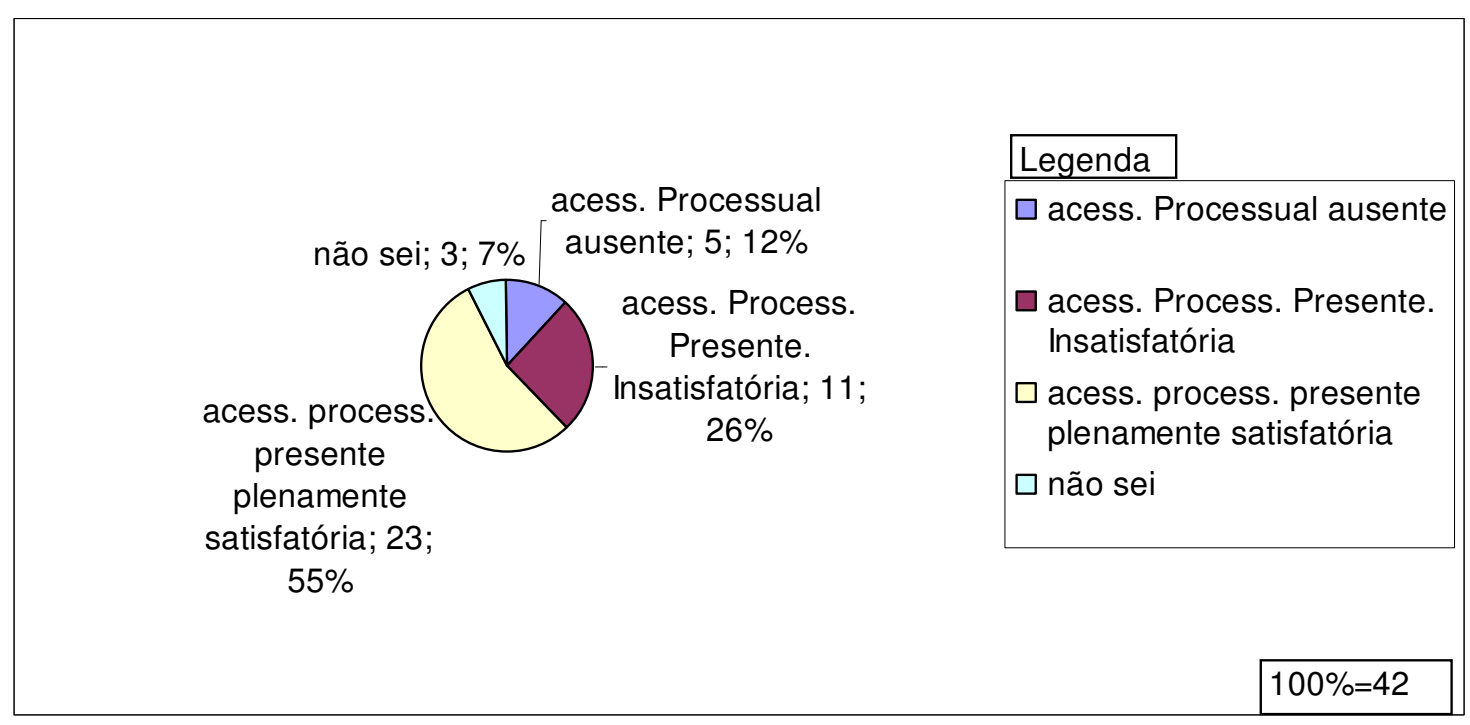

O grau de acessibilidade para a processualidade das comissões temáticas dos CMAS permite saber se quando elas acontecem são munidas das deliberações anteriores dos CMAS, pois essas resoluções são definições que devem ser observadas para a discussão dos temas propostos a fim de se propor encaminhamentos, até mesmo o da necessidade de se rever as deliberações tomadas, quando elas não se aplicarem a realidade social municipal, no que tange à Assistência Social.

A acessibilidade processual ausente, igual a $12 \%$, é quando essas comissões acontecem sem que essas deliberações ou resoluções sejam revistas.

A acessibilidade processual insatisfatória significa que nem sempre as comissões temáticas acontecem com essas resoluções e deliberações, anteriores, tomadas pelos CMAS. A acessibilidade processual plenamente satisfatória corresponde ao fato dessas comissões temáticas só acontecerem com posse dessas resoluções e deliberações, para discussão dos temas propostos.

Deste modo a soma da acess. Processual ausente e da acess. Processual Presente Insatisfatória igual a 38\% demonstra uma desarticulação desse enlace o que suscita uma ação conservadora e contraditória as exigências do SUAS. As comissões temáticas devem ter um papel fundamental de subsidiar as ações dos conselhos e se elas funcionam dessincronizadas com as próprias deliberações desse, dificulta o eixo controle social ser efetivo nas suas ações para a gestão da Assistência Social. 
Gráfico 7- Grau de acessibilidade relacionada ao fluxo de informações do circuito CEAS/conselheiros CMAS

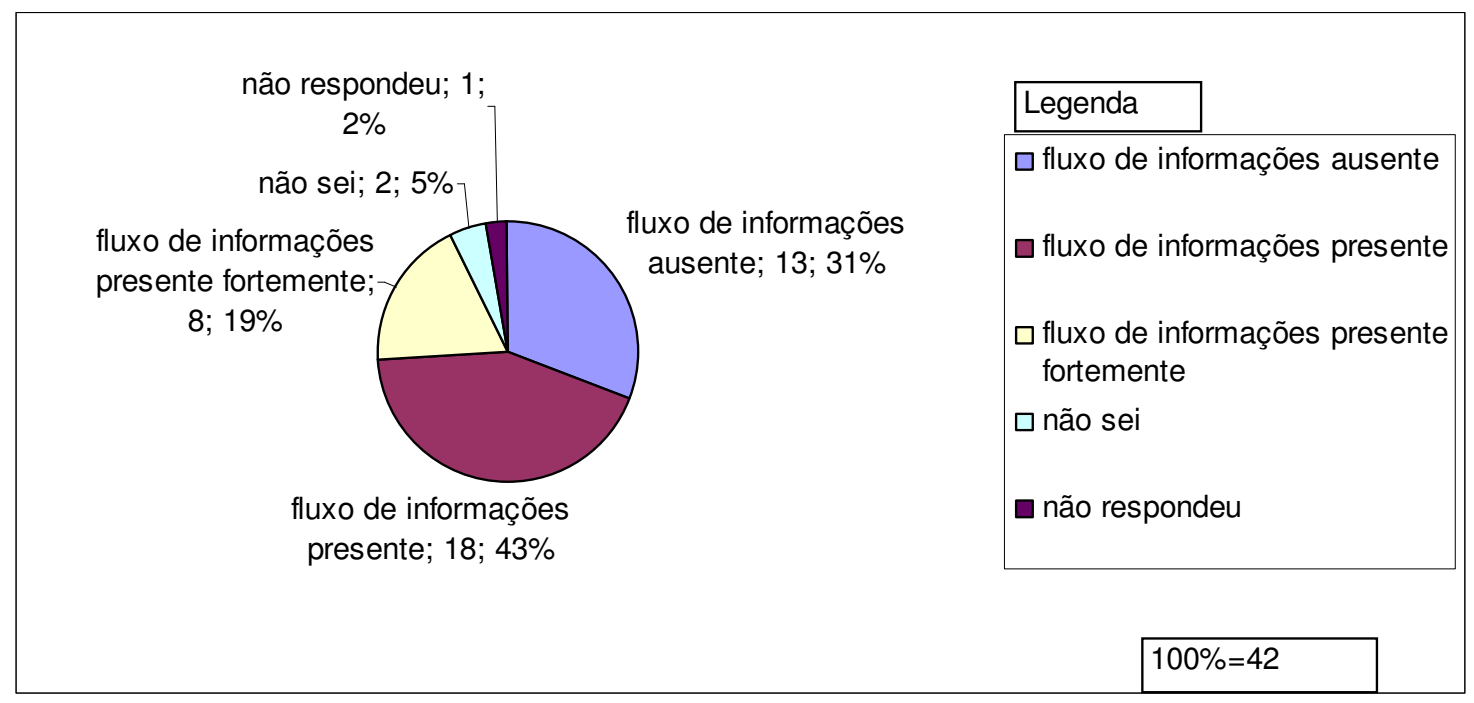

O grau de acessibilidade do fluxo indica o volume das informações estratégicas produzidas pelo CEAS e seu respectivo repasse para os conselheiros da CMAS. A troca de informações desse enlace e circuito, utilizando um meio ágil e rápido para comunicação, como a internet, é importante para a articulação desses conselhos nas suas respectivas esferas de gestão. Pois isto proporciona uma dinamização para o controle social e gestão do SUAS na região, entretanto pode se observar o considerável número de $31 \%$ da inexistência desse fluxo informacional entre o CEAS e os conselheiros CMAS. Depreende-se também que o fluxo de informações presentes em torno de $43 \%$, referentes aqueles conselheiros do CMAS que recebem as deliberações do CEAS, mas não via Internet, o que deixa o processo lento, interfere diretamente nos processos de trabalho e articulação dos e entre os conselhos, visto a gama de informações disponíveis na rede, suscetíveis a mudanças drásticas em um tempo muito curto, o que não proporciona uma intersetorialidade entre os conselhos articulada. O fluxo de informações presente fortemente, o mais eficiente diante do grande número de informações em circulação, é de apenas 19\% o que ressalta contradições técnicooperacionais para a intersetorialidade dos conselhos. 
Gráfico 8- Grau de acessibilidade participativa dos conselheiros nas atividades virtuais extras proporcionadas pelo MDS

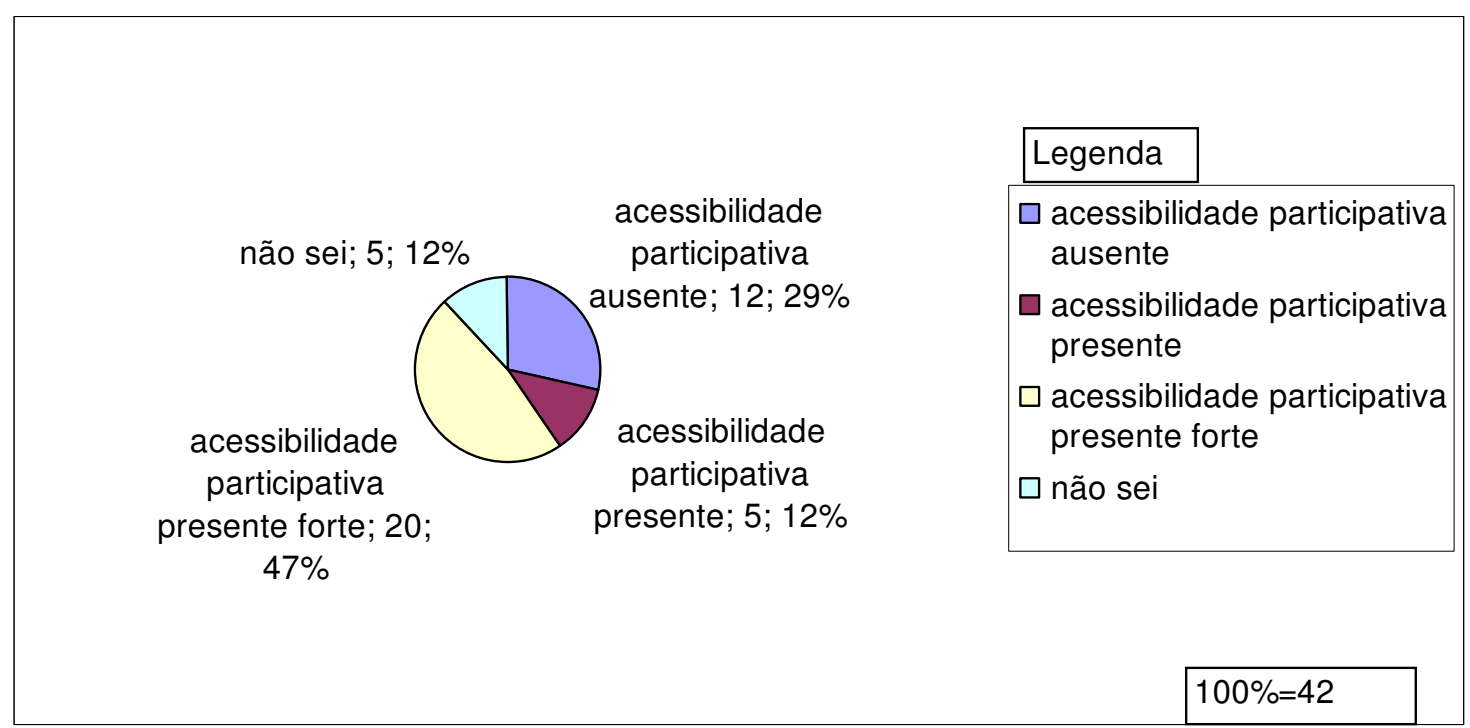

O grau de acessibilidade participativa está relacionado com as atividades telecomunicacionais e virtuais como as tele-conferências e os fóruns virtuais articulada pelo MDS para a integração dos conselhos nas três instâncias. Nesse intuito procurou-se evidenciar a acessibilidade participativa dos conselheiros municipais nesses espaços virtuais e telecomunicacionais de integração. A acessibilidade participativa ausente de $29 \%$ demonstra um alto grau de não participação desses conselheiros nesses espaços socioinformacionais, o que pode resultar numa menor integração desses conselhos nas três instâncias. A acessibilidade participativa presente, está associada ao número de conselheiros que, já participaram de fóruns virtuais e teleconferências, mas não relacionados à Assistência Social, o número de $12 \%$ de conectividade participativa presente pode indicar problemas quanto a divulgação dessas atividades, não permitindo a participação desses conselheiros nesses espaços.

A acessibilidade participativa presente forte é igual ao número de conselheiros que participam ou participaram desses eventos virtuais e telecomunicacionais, o número de $47 \%$ indica, apesar de não atingir a metade do total do retorno, que isso tem sido uma prática cada vez mais crescente de apreensão das NTICs por estes conselheiros para o uso de suas atividades de exercício do controle social da PNAS. 


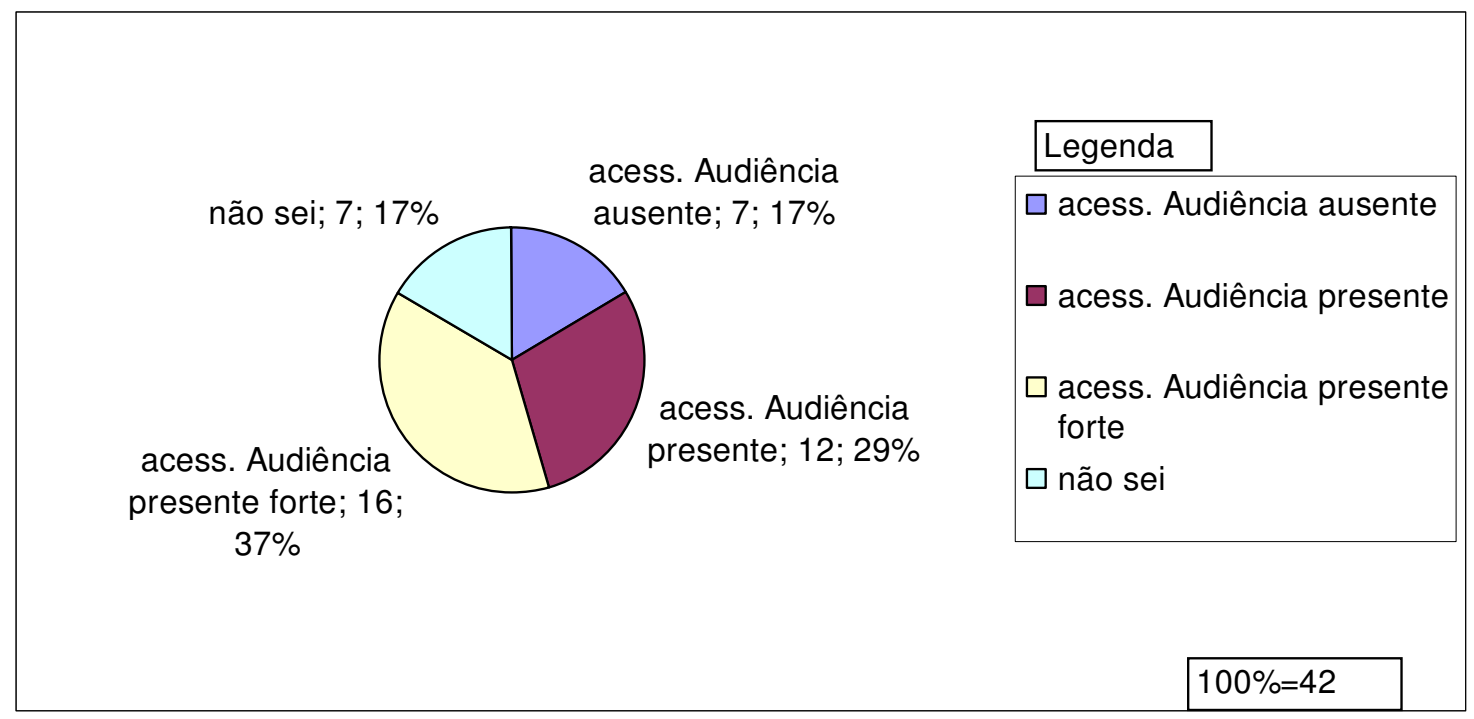

Uma das metas do Plano Decenal da Assistência Social no período 2007 - 2008 foi o de aumentar, no que toca o eixo controle social do SUAS, a fiscalização do funcionamento dos Fundos de Assistência Social em cada esfera de governo. O InfoSUAS disponibiliza os recursos que foram repassados do fundo federal para os fundos municipais. Deste modo a acessibilidade tipo audiência demonstra o acompanhamento dos conselheiros à esse aplicativo para fiscalização dos repasses. Pode-se observar o número considerável de acessibilidade audiência ausente, ou seja, dos conselheiros que não acessam esse aplicativo como um meio de fiscalização de $17 \%$. Pode-se destacar, também, o auto grau de acessibilidade audiência presente que representa o número de conselheiros de $29 \%$ que acessam outros meios para a fiscalização do repasse dos fundos, resta saber que meios seriam esses. O não uso da Rede SUAS, via aplicativo do Info-SUAS pode causar uma morosidade e ineficiência quanto as metas propostas pelo Plano Decenal que visava aumentar a fiscalização dos fundos pelos conselhos de Assistência Social. Assim sendo constata-se contradições tipo audiência de monitoramento dos fundos para o cumprimento das metas do Plano Decenal no período de 2007-2008. A acessibilidade audiência presente forte corresponde aos conselheiros que utilizam o aplicativo InfoSUAS para fiscalização dos repasses federais cofinanciados à Assistência Social, entretanto esse número ainda é baixo, pois $37 \%$ mostraram apreender esse aplicativo para eficácia de monitoramento e fiscalização do fundo federal. 


\subsection{Diretividade Política}

Gráfico 10- Orientação de direção do vetor informacional que conforma a atitude informacional dos conselheiros.

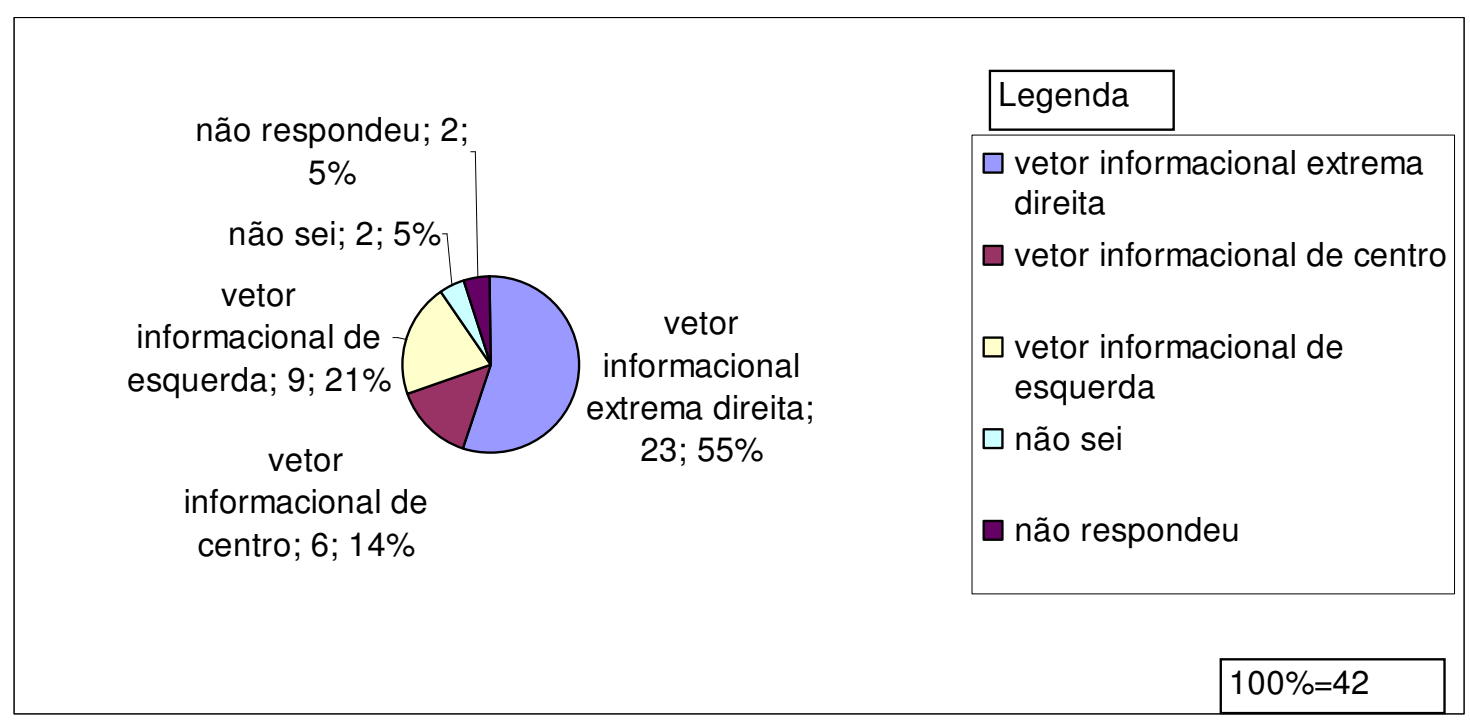

$\mathrm{O}$ vetor de atitude informacional proativa dos conselheiros municipais na participação da elaboração das pautas dos fóruns regionais de Assistência Social permite saber se eles estão tendo uma postura política mais conservadora ou inovadora na Lógica do SUAS. O vetor informacional de extrema direita representa os conselheiros que nunca participaram da elaboração das pautas nos fóruns regionais. $\mathrm{O}$ número expressivo de $55 \%$ indica que os conselheiros municipais ainda têm uma postura extremamente conservadora com relação a sua participação na elaboração das pautas dos fóruns regionais. $\mathrm{O}$ vetor informacional de centro são aqueles conselheiros que já participaram na elaboração de pautas alguma vez, mas não exatamente em um fórum regional, o que indica um perfil não tão conservador, pois costumam participar na elaboração das pautas para discussão, e nem a - conservador, totalmente, pois não têm uma atitude informacional pró-ativa para ocupar os espaços dos fóruns regionais. $\mathrm{O}$ vetor informacional de extrema esquerda é equivalente aos conselheiros que participam da elaboração das pautas, inclusive nos fóruns regionais, entretanto essa vetorial atitude proativa informacional dos conselheiros se mostra baixa, porquanto $21 \%$ desses assumem essa postura. 
Gráfico 11- Orientação do vetor direcional para fiscalização da mesa diretora do conselho.

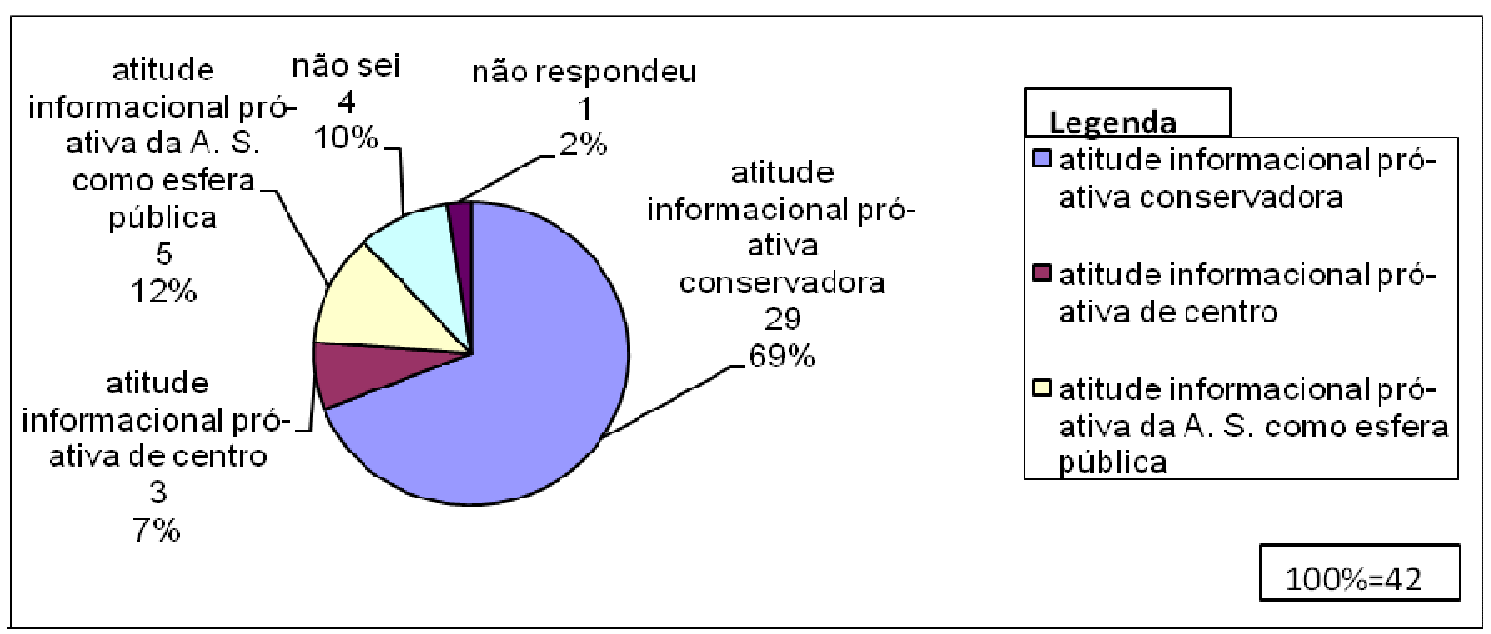

A intensidade da atitude informacional proativa do conselheiro está relacionada, nesse caso, para a fiscalização da mesa diretora do conselho. Aqueles conselheiros que já se utilizaram da internet para fiscalizar os atos da mesa diretora, possuem atitude informacional proativa progressista na concepção de Assistência Social como esfera pública, entretanto esse número se mostra baixo em torno de $12 \%$ A atitude informacional proativa de centro representa aqueles conselheiros que já fiscalizaram a mesa diretora de outras formas que não aquelas via internet.

Destaca-se mais uma vez o conservadorismo da orientação político e técnicooperacional dos conselheiros que não possuem atitude informacional proativa para fiscalização da mesa diretora, via internet, em torno de 69\%. Esse dado revela uma contradição existente, pois apesar de as NTIC's serem fato concreto e cada vez mais recorrente, passando a serem indispensáveis aos sujeitos responsáveis pela fiscalização, eles (as) ainda não apropriaram essa ferramenta no seu cotidiano. 
Gráfico 12- Orientação do vetor direcional relacionada à intensidade da atitude para consulta da Rede SUAS pelos conselheiros do CMAS antes das conferências.

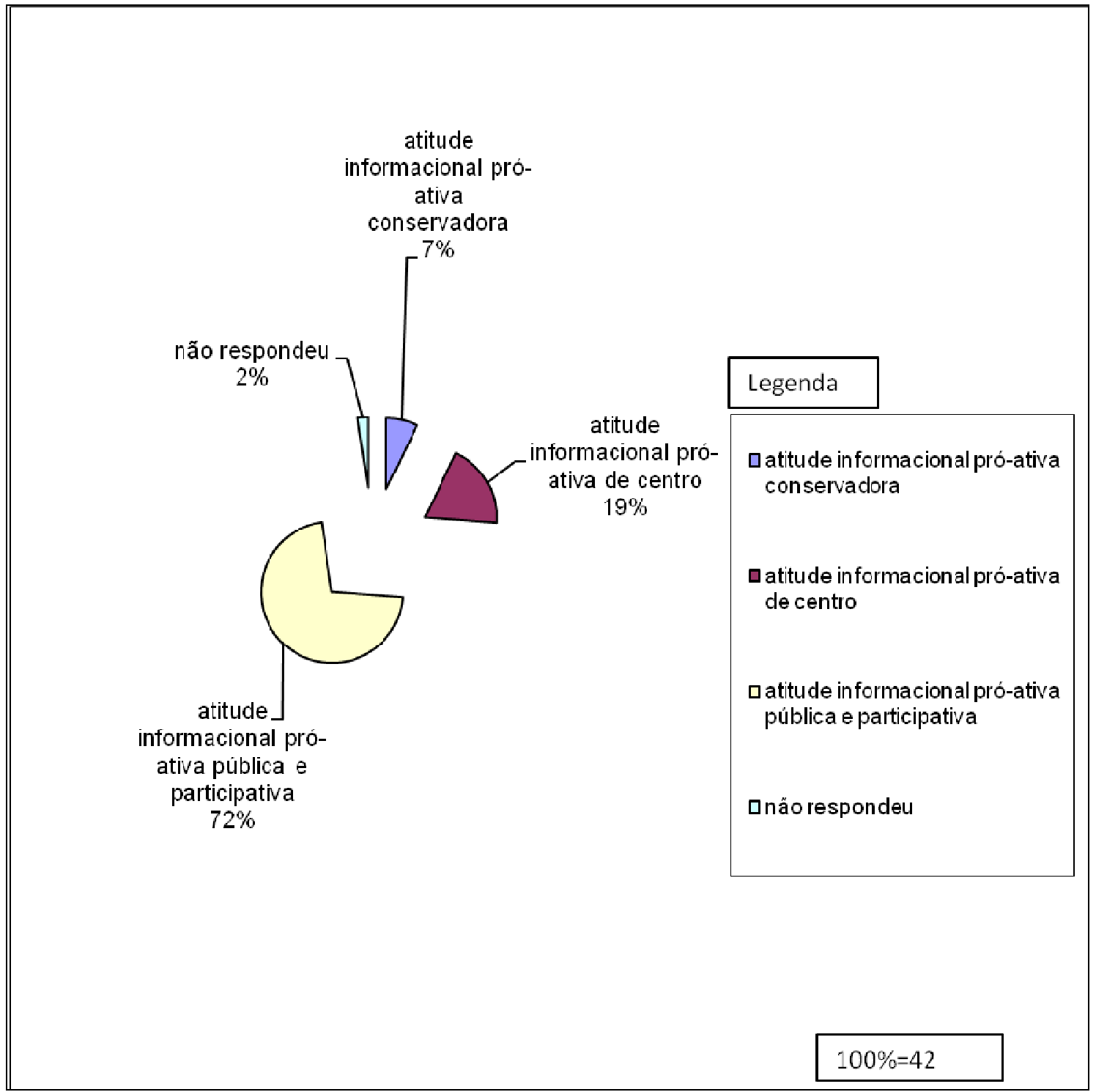

Visto a riqueza de informações que a Rede SUAS disponibiliza para os respectivos níveis de gestão e o controle social, é imprescindível que os conselheiros façam uso dela antes dos momentos deliberativos para que estejam respaldados nos seus posicionamentos e encaminhamentos. Deste modo, a atitude informacional proativa conservadora, correspondente aos conselheiros que não se utilizam dessa ferramenta, antes das conferências, se mostrou reduzido, porquanto apenas $7 \%$ não consultam a Rede SUAS antes dessas conferências. A atitude informacional de centro é referente ao número de conselheiros que costumam consultar a Rede SUAS, mas não antes da realização das conferências. A atitude informacional proativa na lógica democrática e participativa, contra a vertente conservadora, mostrou-se expressiva com $72 \%$ indicando uma nova cultura de gestão e controle social incluindo as NTICs. 
Gráfico 13- Orientação do vetor direcional relacionada à intensidade da atitude informacional Georeferenciada do conselheiro de modo que ele influencie as decisões do conselho

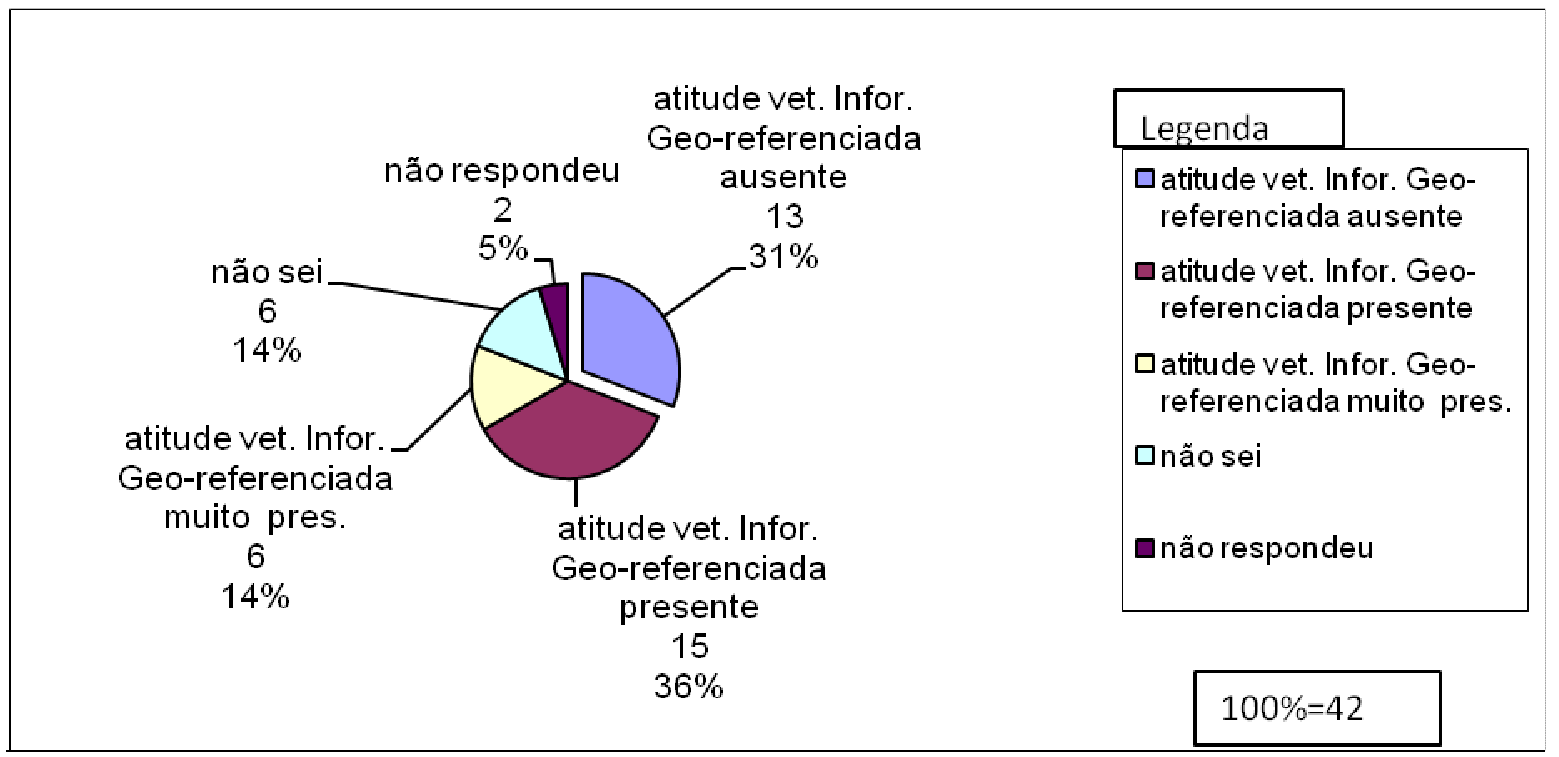

A atitude vetorial informacional geo-referenciada esta de acordo com a orientação direcional dos conselheiros, tomando por base o GeoSUAS, para influenciar o CMAS em suas ações deliberativas. A atitude vetorial informacional geo-referenciada ausente é igual ao número de conselheiros que não usam esse aplicativo para influenciar as decisões no CMAS. Esse número é expressivo em torno de $31 \%$ e está coadunado com práticas, no que diz respeito às diretivas políticas, conservadoras, pois não apreendem as potencialidades que os dados Geo-referenciados oferecem pautadas na região e no território. A atitude informacional vetorial informacional geo-referenciada de centro, corresponde ao número de conselheiros que acessam o GeoSUAS, mas não usam os seus dados para influenciar o conselho a respeito de suas informações.

A direção vetorial que expressa orientações políticas progressistas por meio de atitudes informacionais vetoriais informacionais geo-referenciadas muito presente, onde os conselheiros sempre se utilizam desse aplicativo para influenciar o conselho, ainda é muito reduzida com o percentual de $14 \%$. O que mostra a tendência conservadora e de centro no que diz respeito ao uso desse aplicativo para influenciar o CMAS. 


\section{Considerações Finais}

Finalizar este trabalho final de conclusão de curso tem para mim um significado muito especial, pois se por um lado ele representa um processo de acúmulo de conhecimentos vividos desde o meu período de estágio supervisionado no MDS, por outro representa uma notória relevância para minha vida profissional.

Num segundo momento não se trata aqui de responder de forma taxativa a minha hipótese inicial, mas sim de reproblematizá-la a outro nível por meio dos dados levantados como, por exemplo, o fato de uma taxa expressiva da tendência conservadora e de centro dos (as) conselheiros (as) que não usam, ou utilizam em partes esses mecanismos fundamentais, como os aplicativos da rede SUAS, antes de processos sociais, de ordem deliberativa e para o controle social, em plena era socioinformacional, está relacionado a uma cultura que não é estrita aos conselheiros de Assistência Social, de não uso das NTIC's para o exercício da prática diária.

Nesse sentido é possível visualizar novos projetos de pesquisa por meio de novas problemáticas sinalizadas do que realmente concluir respondendo a hipótese levantada, ou seja, se existem ou não contradições ético-políticas e técnico-operacionais na Rede SUAS. Entretanto não posso deixar de fazer algumas indicações sobre os limites e possibilidades por nós identificados nesta pesquisa sobre o grau de apropriação das NTIC's pelos conselheiros de Assistência Social

O estudo dos enlaces, circuitos e fluxos informacionais engendrados pelo SUAS e seu Sistema de Informação, a partir das macro-categorias acessibilidade, conectividade e diretividade política da rede dos conselheiros municipais de Assistência Social, possibilitou a identificação de contradições socioinformacionais na implantação da Rede SUAS.

A análise a partir da conectividade demonstrou a composição orgânica da rede levantada, relevando tanto o meio presencial como o virtual. Os resultados obtidos foram que os conselheiros e os demais nós dos enlaces e circuitos como: a base de representados, o CNAS, a secretaria executiva do CMAS, a Rede SUAS, se dão de forma interativa, descentralizada democrática e participativa visto que os resultados foram positivos nesta direção.

No que diz respeito à acessibilidade, os enlaces, os circuitos e os fluxos, foram reveladas contradições relacionadas à eficácia e a eficiência das metas do Plano Decenal 
e as diretrizes da NOBSUAS direcionadas ao eixo controle social, posto que os resultados obtidos não corresponderam ao que foi estipulado tanto nas metas do Plano Decenal e nem na NOBSUAS, pois o inter relacionamento entre os conselhos estaduais e municipais se demonstraram desarticulados, porquanto não se utilizavam dos meios informacionais e comunicacionais existentes na sociedade contemporânea para se interagirem em torno das atividades conjuntas para o controle social do Estado.

Foi visto, também, que as ações de controle democrático, na fiscalização do repasse dos fundos, uma das metas do Plano Decenal no período 2007 - 2008, não foi atendida na sua totalidade, porquanto menos da metade dos conselheiros visitam o aplicativo InfoSUAS correspondente ao repasse dos recurso co-financiados federais.

A categoria diretividade política revelou o caráter altamente conservador do vetor informacional dos conselheiros contradizendo os resultados positivos relacionados à interatividade, descentralização, democratização e participação dos enlaces, circuitos e fluxos analisados pela categoria conectividade da sua composição orgânica.

A categoria inclusão digital dos conselheiros mostrou dados relevantes como o número de mais de $60 \%$ dos conselheiros que não usam os espaços sociais da rede (internet) para informar e se manterem informados a cerca de temas relacionados à Assistência Social, ou seja, é necessário que esses espaços também sejam ocupados para a interatividade e articulação dos conselheiros.

Por fim, a realização do conjunto dessa pesquisa se mostrou de alta relevância, pois fatos concretos, na sociedade brasileira, como o controle democrático, por meio dos conselhos gestores, aliadas à implementação das políticas sociais e as NTICs no contexto da Revolução Informacional se configuram como elementos, nas sociedades atuais, estritamente relacionados para a construção de um projeto societário alternativo em direção a uma nova sociedade. 


\section{Referências Bibliográficas}

ALBUQUERQUE, Simone A. \& CRUS, José F. Um Sistema Único de Assistência Social para o Brasil. Rede SUAS: Gestão e Sistema de Informação para o Sistema Único de Assistência Social. Org. Luziele Tapajós \& Roberto Wagner da Silva Rodrigues. Brasília: MDS p. 12-21, 2007.

BRASIL. CapacitaSUAS. SUAS: configurando os eixos de mudança. Vol. 1, Brasília: MDS, 2008.

BRASIL. CapacitaSUAS. Desafios da gestão do SUAS nos municípios e estados. Vol. 2, Brasília: MDS, 2008.

BRASIL, Presidência da República, Lei Orgânica da Assistência Social, Lei n 8742 , de 7 de dezembro de 1993, publicada no DOU de 8 de dezembro de 1993.

BRASIL. Plano Decenal: SUAS Plano 10. MDS/SNAS, 2007.

BRASIL. SUAS. Implicações do SUAS e da gestão descentralizada na atuação dos conselhos de Assistência Social. Vol. 2, 2006.

BRASIL. SUAS. Orientações a cerca dos conselhos e do controle social da política pública de Assistência Social. Cartilha 1. CNAS/MDS.

BRASIL, Tribunal de Contas da União. Orientações para Conselhos da Área de Assistência Social. Brasília: TCU, 4 Secretária de Controle Externo, 2007.

CAMPOS, Edval Bernardino. Assistência Social do descontrole ao controle social. Serviço Social \& Sociedade, $\mathrm{n}^{\circ} 88,2006$, p. 101-119.

CAPACITAÇÃO EM SERVIÇO SOCIAL POLÍTICA SOCIAL, módulo 3. Brasília: UnB, Centro de Educação Aberta, Continuada a Distância, 2000.

CASTELLS, Manuel. A sociedade em Redes. São Paulo: Paz e Terra, 2003.

CONSELHO NACIONAL DE ASSISTÊNCIA SOCIAL, Resolução n ${ }^{\circ} 237$ de 14 de Dezembro de 2006, publicada no DOU n 246 de 26 de Dezembro de 2006.

DEMO, Pedro. Metodologia Científica em Ciências Sociais. $3^{\circ}$ Ed.rev. e ampliada. São Paulo: Atlas, 1995.

GOHN, Maria da Glória. Conselhos Gestores e participação sociopolítica. São Paulo, Cortez, 2001. Coleção questões da nossa época; v.84.

LOJKINE, Jean. A Revolução Informacional. São Paulo. Cortez, 1995.

MARCONI, M. A. \& LAKATUS. Técnicas de pesquisa: Planejamento e execução de pesquisas, amostragens e técnicas de pesquisas, elaboração, análise e interpretação de dados. $3^{\circ}$ Ed. São Paulo: Atlas, 1996. 
MEDEIROS, Quezia Arcoverde. A Rede SUAS e os municípios: o projeto éticopolítico profissional e sua expressão. Brasília: UnB, 2007.

PEREIRA, Potyara A. P. A assistência social na perspectiva dos direitos- críticas aos padrões dominantes de proteção aos pobres no Brasil—Brasília: Thesaurus, 1996.

PEREIRA, Potyara A. P. Controle democrático com garantia de direitos. Brasília: Subsecretaria dos Direitos Humanos \& Subsecretaria de Promoção e Defesa dos Direitos Humano, 2005.

PEREIRA. Potyara A. P. \& BRAVO. Maria Inês S. Política social e democracia. São Paulo: Cortez, 2007.

PEREIRA, Potyara A. P. Política Social: temas \& questões. São Paulo: Cortez, 2008.

POLÍTICA NACIONAL DE ASSISTÊNCIA SOCIAL- PNAS, aprovada pelo Conselho Nacional de Assistência Social por intermédio da resolução ${ }^{\circ}{ }^{\circ}$ 145, de 15 de outubro de 2004 e publicada no Diário Oficial da União- DOU do dia 28 de outubro de 2004.

RAICHELIS, Raquel. Esfera Pública e conselhos de assistência social: caminhos da construção democrática. $2^{\circ}$ Ed. Ver. São Paulo, Cortez, 2000.

RAMOS, M. H. Rauta. Metamorfoses Sociais e Políticas Urbanas - Rio de Janeiro: DP\&A, 2002.

RODRIGUES, Roberto Wagner da S. Centralização e Distribuição de Dados e Informação no Campo das Políticas Sociais: a experiência do MDS. Rede SUAS: Gestão e Sistema de Informação para o Sistema Único de Assistência Social. Org. Luziele Tapajós \& Roberto Wagner da Silva Rodrigues. Brasília: MDS p. 40-55, 2007.

SHAFF, Adam. A sociedade informática: as conseqüências sociais da segunda revolução industrial. $4^{\circ}$ Edição, São Paulo: Editora da Universidade Paulista: Brasiliense, 1995.

SOUZA, Perci C. Potencialidades políticas nas práticas de comunicação da CUT: O uso da internet e o Platô informacional do DF. Rio de Janeiro, 2005.

SOUZA, Perci C. Uma crítica francesa a cerca do espaço urbano. Ser Social. Brasília n. 17, p. 59-112. 2005.

SPOSATI, Aldaíza. A menina LOAS. Um processo de construção da Assistência Social. São Paulo: Cortez, 2004.

SPOSATI, Aldaíza \& FALCÃO, M. C. LBA: Identidade e efetividade das ações no enfrentamento da pobreza brasileira. São Paulo, educ, 1989. 
TAPAJÓS, Luziele. A Gestão da Informação em Assistência Social. Rede SUAS: Gestão e Sistema de Informação para o Sistema Único de Assistência Social. Brasília, DF, p.70-88, 2007.

VIEIRA, Evaldo. O Estado e a sociedade civil perante o ECA e a LOAS. Serviço Social \& Sociedade, São Paulo, ano XIX n. 56, p. 9-22, 1998. 


\section{Anexos/Apêndices}

\section{1- Ofício apresentando a pesquisa aos conselheiros enviado, no dia 13/07/2009, pelo}

e-mail institucional do MDS: Jose.crus@mds.gov.br

Prezado Senhor(a) Conselheiro(a),

Ao cumprimentá-lo (la), em nome da nossa equipe do MDS, tenho a satisfação de encaminhar, em anexo, um questionário de pesquisa de autoria do estudante Eduardo Augusto Rodrigues Barros, nosso ex-estagiário da SNAS/MDS, do curso de Serviço Social, que está sob a orientação do Prof. Dr. Perci Coelho de Souza, da Universidade de Brasília - UnB, sobre o uso das novas tecnologias de informação e comunicação, utilizada pelos conselheiros da política pública de assistência social.

Este questionário busca coletar dados sobre os limites e potencialidades no uso e circulação das informações na Rede SUAS e seus respectivos aplicativos (SUAS-Web; Info-SUAS, Geo-SUAS, etc.). O resultado dessa pesquisa será de fundamental importância para que possamos qualificar e capacitar os conselheiros municipais, com objetivo de aprimorar cada vez mais os instrumentos de gestão utilizados pelo gestor e conselheiros da assistência social, na perspectiva da gestão compartilhada.

Nesse sentido, recomendamos QUE APENAS UM CONSELHEIRO DA MESA DIRETORA, ESCOLHIDO DE FORMA ALEATÓRIA (SUGERIMOS SORTEIO), preencha esse instrumento de coleta de dados. O instrumento é auto-explicativo e de fácil preenchimento que não levará mais do que alguns minutos. Por outro lado, os resultados desta pesquisa contribuirá com o processo de implantação do SUAS, neste ano em que comemoramos quatro anos deste processo de implantação.

Os questionários respondidos deverão ser enviados por e-mail ao seguinte endereço eletrônico: duarquivos84@gmail.com.

Atenciosamente,

José Crus

Coordenador-Geral

Departamento de Gestão do SUAS

Secretaria Nacional de Assistência Social

Ministério do Desenvolvimento Social e Combate à Fome 


\subsection{Ofício solicitando que os municípios não deixem de preencher os questionários, enviado no dia 29/07/2009 pelo e-mail duarquivos84@ gmail.com}

Prezado secretário(a) executivo(a),

Conselho Municipal de Assistência Social

Ao cumprimentá-lo (la), reiteramos a importância da participação de um conselheiro municipal, integrante da mesa diretora, somente para aqueles municípios que ainda NÃO enviaram o questionário preenchido sobre a referida pesquisa intitulada: "Perfil Informacional dos conselheiros municipais de assistência social: as contradições na implantação da Rede-SUAS na perspectiva dos conselhos de assistência social dos municípios habilitados na Gestão Plena do SUAS". No primeiro momento, estipulamos prazo até o dia 31 de julho de 2009, tendo em vista o prazo para conclusão deste trabalho na Universidade de Brasília - UnB. Este questionário deve ser anexado e enviado ao e-mail: duarquivos84@gmail.com.

Vale ressaltar, que o produto deste trabalho irá contribuir com 0 processo de implantação e, consolidação do Sistema Único de Assistência Social, ora implantado no Brasil. Comemoramos em julho deste ano quatro anos de implantação deste sistema e as respostas dos conselheiros nos indicarão ou não o uso das ferramentas de gestão disponibilizados para potencializar e fortalecer cada vez mais o controle social e a participação popular na gestão da política pública de assistência social, reafirmando seu caráter democrático e participativo, conforme prescrito nas legislações em vigor.

Pela importância da pesquisa ora apresentada, informamos que ainda receberemos os questionários respondidos até o dia 05 de agosto de 2009. Anexamos, novamente, o questionário e nos colocamos à disposição deste conselho para quaisquer informações que julgarem necessárias e cabíveis.

Atenciosamente,

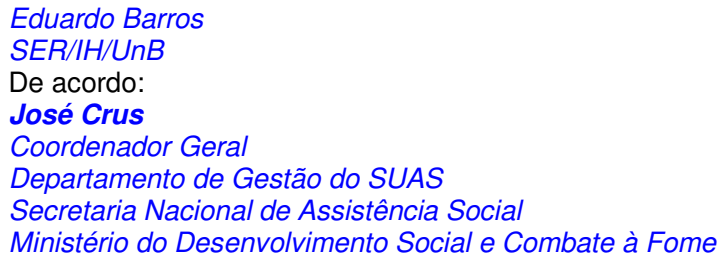


TOTAL E PORCENTAGEM DE MUNICÍPIOS HABILITADOS EM GESTÃO INICIAL, BÁSICA E PLENA, POR ESTADO, SEGUNDO A NOB SUAS 2005

20_maio_2009

\begin{tabular}{|c|c|c|c|c|c|c|c|c|c|c|c|c|c|}
\hline \multirow[b]{2}{*}{ UF/ Região } & \multirow{2}{*}{$\begin{array}{c}\text { Total de } \\
\text { Municipios }\end{array}$} & \multicolumn{8}{|c|}{ G EST $\mathrm{A} O$} & \multirow[b]{2}{*}{$\mathrm{GB}+\mathrm{GP}$} & \multirow[b]{2}{*}{$\%$} & \multirow[b]{2}{*}{$\mathrm{Gl}+\mathrm{GB}+\mathrm{GP}$} & \multirow[b]{2}{*}{$\%$} \\
\hline & & Inicial & $\%$ & Básica| & $\%$ & Plena & $\%$ & $\begin{array}{c}\text { Não } \\
\text { Habilitados }\end{array}$ & $\%$ & & & & \\
\hline
\end{tabular}

Norte

\begin{tabular}{l|r|r|r|r|r|r|r|r|r|r|r|r|r|r|r}
\hline Acre & 22 & 0 & 0,0 & 21 & 95,5 & 1 & 4,5 & & 0 & 0,0 & 22 & 100,0 & 22 & 100,0 \\
Amapá & 16 & 10 & 62,5 & 6 & 37,5 & 0 & 0,0 & & 0 & 0,0 & 6 & 37,5 & 16 & 100,0 \\
Amazonas & 62 & 2 & 3,2 & 55 & 88,7 & 5 & 8,1 & & 0 & 0,0 & 60 & 96,8 & 62 & 100,0 \\
Pará & 143 & 1 & 0,7 & 137 & 95,8 & 5 & 3,5 & 0 & 0,0 & 142 & 99,3 & 143 & 100,0 \\
Rondônia & 52 & 1 & 1,9 & 51 & 98,1 & 0 & 0,0 & 0 & 0,0 & 51 & 98,1 & 52 & 100,0 \\
Roraima & 15 & 0 & 0,0 & 14 & 93,3 & 1 & 6,7 & & 0 & 0,0 & 15 & 100,0 & 15 & 100,0 \\
Tocantins & 139 & 38 & 27,3 & 97 & 69,8 & 1 & 0,7 & & 3 & 2,2 & 98 & 70,5 & 136 & 97,8 \\
\hline Total & 449 & 52 & 11,6 & 381 & 84,9 & 13 & 2,9 & & 3 & 0,7 & 394 & 87,8 & 4,6 & 99,3 \\
\hline
\end{tabular}

Nordeste

\begin{tabular}{|c|c|c|c|c|c|c|c|c|c|c|c|c|c|}
\hline Alagoas & 102 & 1 & 1,0 & 100 & 98,0 & 0 & 0,0 & 1 & 1,0 & 100 & 98,0 & 101 & 99,0 \\
\hline Bahia & 417 & 45 & 10,8 & 344 & 82,5 & 17 & 4,1 & 11 & 2,6 & 361 & 86,6 & 406 & 97,4 \\
\hline Ceará & 184 & 0 & 0,0 & 170 & 92,4 & 14 & 7,6 & 0 & 0,0 & 184 & 100,0 & 184 & 100,0 \\
\hline Maranhão & 217 & 5 & 2,3 & 204 & 94,0 & 7 & 3,2 & 1 & 0,5 & 211 & 97,2 & 216 & 99,5 \\
\hline Paraíba & 223 & 3 & 1,3 & 199 & 89,2 & 14 & 6,3 & 7 & 3,1 & 213 & 95,5 & 216 & 96,9 \\
\hline Pernambuco & 185 & 7 & 3,8 & 172 & 93,0 & 5 & 2,7 & 1 & 0,5 & 177 & 95,7 & 184 & 99,5 \\
\hline Piauí & 223 & 23 & 10,3 & 195 & 87,4 & 1 & 0,4 & 4 & 1,8 & 196 & 87,9 & 219 & 98,2 \\
\hline Rio G do Norte & 167 & 0 & 0,0 & 159 & 95,2 & 7 & 4,2 & 1 & 0,6 & 166 & 99,4 & 166 & 99,4 \\
\hline Sergipe & 75 & 0 & 0,0 & 74 & 98,7 & 1 & 1,3 & 0 & 0,0 & 75 & 100,0 & 75 & 100,0 \\
\hline Total & 1.793 & 84 & 4,7 & 1.617 & 90,2 & 66 & 3,7 & 26 & 1,5 & 1.683 & 93,9 & 1.767 & 98,5 \\
\hline
\end{tabular}

Centro Oeste

\begin{tabular}{|c|c|c|c|c|c|c|c|c|c|c|c|c|c|}
\hline Goiás & 246 & 50 & 20,3 & 192 & 78,0 & 3 & 1,2 & 1 & 0,4 & 195 & 79,3 & 245 & 99,6 \\
\hline Mato G do Sul & 78 & 11 & 14,1 & 36 & 46,2 & 31 & 39,7 & 0 & 0,0 & 67 & 85,9 & 78 & 100,0 \\
\hline Mato Grosso & 141 & 0 & 0,0 & 119 & 84,4 & 22 & 15,6 & 0 & 0,0 & 141 & 100,0 & 141 & 100,0 \\
\hline Total & 465 & 61 & 13,1 & 347 & 74,6 & 56 & 12,0 & 1 & 0,2 & 403 & 86,7 & 464 & 99,8 \\
\hline
\end{tabular}

Sudeste

\begin{tabular}{|c|c|c|c|c|c|c|c|c|c|c|c|c|c|}
\hline Espírito Santo & 78 & 18 & 23,1 & 53 & 67,9 & 7 & 9,0 & 0 & 0,0 & 60 & 76,9 & 78 & 100,0 \\
\hline Minas Gerais & 853 & 221 & 25,9 & 571 & 66,9 & 52 & 6,1 & 9 & 1,1 & 623 & 73,0 & 844 & 98,9 \\
\hline Rio de Janeiro & 92 & 0 & 0,0 & 61 & 66,3 & 31 & 33,7 & 0 & 0,0 & 92 & 100,0 & 92 & 100,0 \\
\hline São Paulo & 645 & 259 & 40,2 & 304 & 47,1 & 74 & 11,5 & 8 & 1,2 & 378 & 58,6 & 637 & 98,8 \\
\hline Total & 1.668 & 498 & 29,9 & 989 & 59,3 & 164 & 9,8 & 17 & 1,0 & 1.153 & 69,1 & 1.651 & 99,0 \\
\hline
\end{tabular}

Sul

\begin{tabular}{|c|c|c|c|c|c|c|c|c|c|c|c|c|c|}
\hline Paraná & 399 & 198 & 49,6 & 163 & 40,9 & 38 & 9,5 & 0 & 0,0 & 201 & 50,4 & 399 & 100,0 \\
\hline Rio G do Sul & 496 & 81 & 16,3 & 346 & 69,8 & 25 & 5,0 & 44 & 8,9 & 371 & 74,8 & 452 & 91,1 \\
\hline Santa Catarina & 293 & 141 & 48,1 & 131 & 44,7 & 21 & 7,2 & 0 & 0,0 & 152 & 51,9 & 293 & 100,0 \\
\hline Total & 1.188 & 420 & 35,4 & 640 & 53,9 & 84 & 7,1 & 44 & 3,7 & 724 & 60,9 & 1.144 & 96,3 \\
\hline TOTAL GERAL & 5.563 & 1.115 & 20,0 & 3.974 & 71,4 & 383 & 6,9 & 91 & 1,6 & 4.357 & 78,3 & 5.472 & 98,4 \\
\hline
\end{tabular}


3- E-mails dos conselhos de Assistência Social dos municípios habilitados na gestão plena do SUAS disponibilizada pelo Ministério do Desenvolvimento Social e Combate à Fome.

\begin{tabular}{|c|c|c|}
\hline$A C$ & RIO BRANCO & \\
\hline AM & COARI & semascoari@bol.com.br \\
\hline$A M$ & FONTE BOA & conselhofonteboa@hotmail.com \\
\hline AM & MANAUS & \\
\hline $\mathrm{AM}$ & MAUES & denydorzane@hotmail.com \\
\hline BA & ALAGOINHAS & cmas.alagoinhas@hotmail.com \\
\hline BA & AMARGOSA & cmas@amargosa.ba.gov.br \\
\hline BA & CAMACARI & \\
\hline BA & FEIRA DE SANTANA & sdsocial@pmfs.ba.gpv.br \\
\hline BA & ILHEUS & cmasios@gmail.com \\
\hline BA & ITABUNA & sds2005sds@ig.com.br \\
\hline BA & JEQUIE & vaniaduartester@gmail.com.br \\
\hline BA & JUAZEIRO & maria.maria44@hotmail.com \\
\hline BA & LAURO DE FREITAS & cmas If@hotmail.com \\
\hline BA & PAULO AFONSO & moreiraclaraana@hotmail.com \\
\hline BA & PORTO SEGURO & japortela@vol.com.br \\
\hline BA & SALVADOR & cmass@salvador.ba.gov.br \\
\hline BA & SANTO ANTONIO DE JESUS & fedmundir@hotmail.com \\
\hline BA & SENHOR DO BONFIM & acanudos@hotmail.com \\
\hline BA & TEIXEIRA DE FREITAS & cmas teixeira@yahoo.com.br \\
\hline CE & ACARAU & janielle.jan@hotmail.com \\
\hline CE & AQUIRAZ & assistenciasocial@aquiraz.ce.gov.br \\
\hline CE & ARACATI & aracaticmas@yahoo.com \\
\hline CE & CAMPOS SALES & cmasc.sales@hotmail.com \\
\hline CE & CAUCAIA & \\
\hline CE & CRATO & liduinasas@yahoo.com.br \\
\hline CE & EUSEBIO & $\underline{\text { articulacaoeusebio@yahoo.com.br }}$ \\
\hline CE & FORTALEZA & cmasfortaleza@yahoo.com.br \\
\hline CE & IGUATU & cmasiguatu@yahoo.com.br \\
\hline CE & JUAZEIRO DO NORTE & $\underline{\text { seastin@bol.com.br }}$ \\
\hline CE & MARACANAU & casadosconselhos@maracanau.ce.gov.br \\
\hline CE & MARANGUAPE & patriciasturdart@yahoo.com.br \\
\hline CE & MISSAO VELHA & cmasmissaov@hotmail.com \\
\hline CE & SOBRAL & cmassobral@sobral.org \\
\hline ES & COLATINA & asocial@colatina.es.gov.br \\
\hline ES & GUACUI & socialguacui@ig.com.br \\
\hline ES & GUARAPARI & setac@guarapari.es.gov.br \\
\hline ES & LINHARES & shirleyperini@hotmail.com \\
\hline ES & SERRA & comasse.es@bol.com.br \\
\hline
\end{tabular}




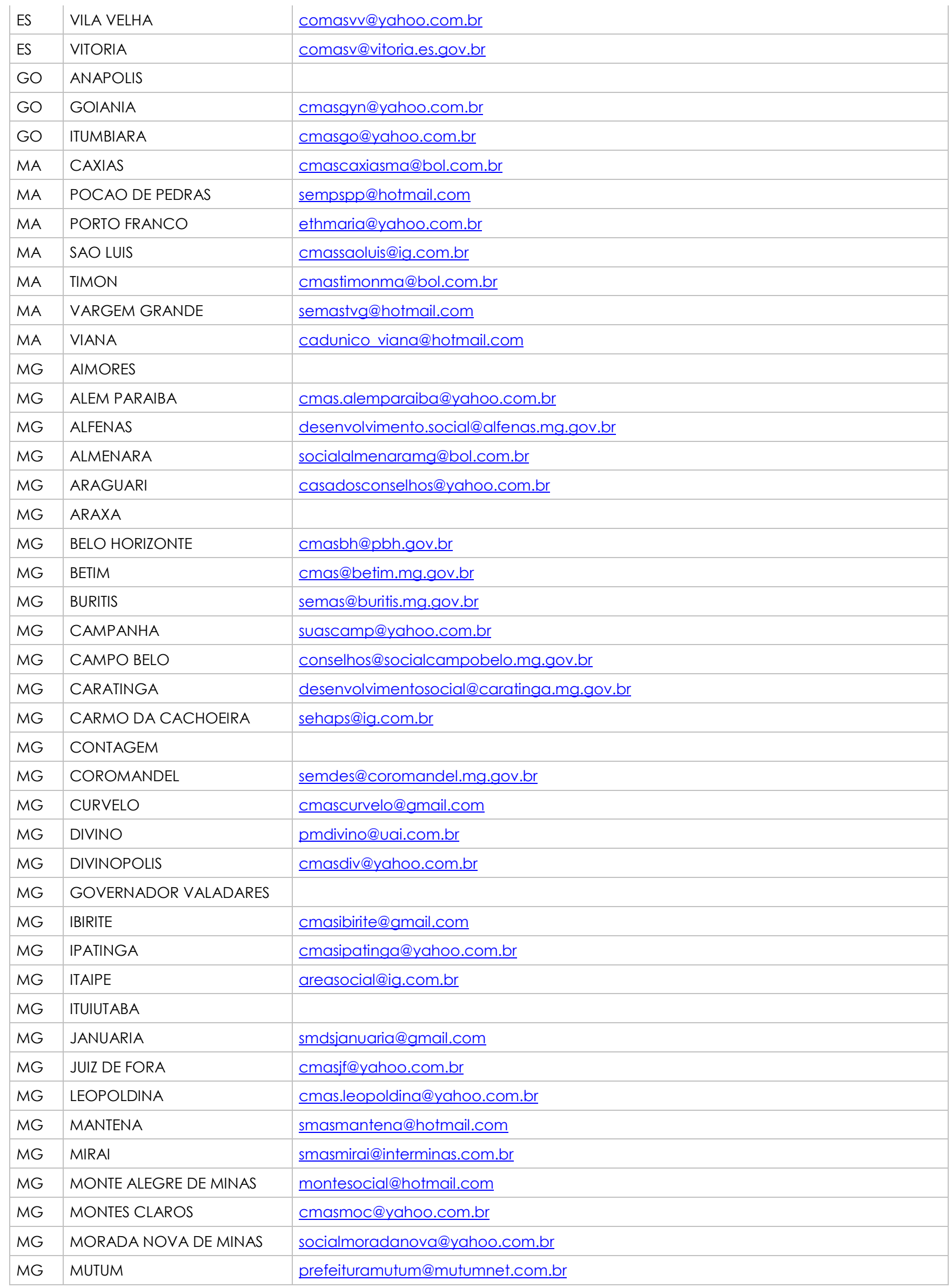




\begin{tabular}{|c|c|c|}
\hline MG & NANUQUE & semasananuque@yahoo.com.br \\
\hline MG & NOVA LIMA & conselhonl@yahoo.com.br \\
\hline MG & OLIVEIRA & oliveira.social@yahoo.com.br \\
\hline MG & OURO PRETO & smac.ouropreto@yahoo.com.br \\
\hline MG & PARACATU & acaosocial@paracatu.mg.gov.br \\
\hline MG & PAVAO & pmpsocial@hotmail.com \\
\hline MG & PITANGUI & cmaspitangui@yahoo.com.br \\
\hline MG & PONTE NOVA & semas@pontenet.com.br \\
\hline MG & RIBEIRAO DAS NEVES & cmasrn@ig.com.br \\
\hline MG & SABARA & \\
\hline MG & SANTO ANTONIO DO MONTE & assistencia_samonte@yahoo.com.br \\
\hline MG & SANTOS DUMONT & zenaidemmd@yahoo.com.br \\
\hline MG & SAO JOAO DEL REI & cmas.sjdr@yahoo.com.br \\
\hline MG & TEOFILO OTONI & casa_dos_conselhos@yahoo.com.br \\
\hline MG & TRES MARIAS & cmas3m@yahoo.com.br \\
\hline MG & UBERABA & cmas@uberaba.mg.gov.br \\
\hline MG & UNAI & cmas@prefeituraunai.mg.gov.br \\
\hline MG & VICOSA & ¡bdinizp@hotmail.com \\
\hline MS & AMAMBAI & smaspref@gmail.com \\
\hline MS & APARECIDA DO TABOADO & conselhomunicipal@bol.com.br \\
\hline MS & BATAGUASSU & assistenciasocialbtg@bol.com.br \\
\hline MS & BATAYPORA & social@bataypora.ms.gov.br \\
\hline MS & BELA VISTA & smasbv@hotmail.com \\
\hline MS & BONITO & cmasbonito@hotmail.com \\
\hline MS & CAMPO GRANDE & cmas@pmcg.ms.gov.br \\
\hline MS & CHAPADAO DO SUL & cmas_cs@hotmail.com \\
\hline MS & CORUMBA & \\
\hline MS & DOURADOS & conselhos.dourados@dourados.ms.gov.br \\
\hline MS & ELDORADO & sas_eldoradoms@hotmail.com \\
\hline MS & GUIA LOPES DA LAGUNA & cmas.guialopes@hotmail.com \\
\hline MS & ITAQUIRAI & cmac.itaquirai@hotmail.com \\
\hline MS & IVINHEMA & sastivinhema@alphasys.com \\
\hline MS & JARDIM & pmjsocial@econet.com.br \\
\hline MS & JUTI & cmas.juti@hotmail.com \\
\hline MS & LADARIO & smasladario@yahoo.com.br \\
\hline MS & LAGUNA CARAPA & \\
\hline MS & MARACAJU & cmasmaracaju@hotmail.com \\
\hline MS & MUNDO NOVO & asocial@rgp.com.br \\
\hline MS & NOVA ANDRADINA & pmna.semcias@bol.com.br \\
\hline MS & PARANAIBA & semas@paranaiba.ms.gov.br \\
\hline
\end{tabular}




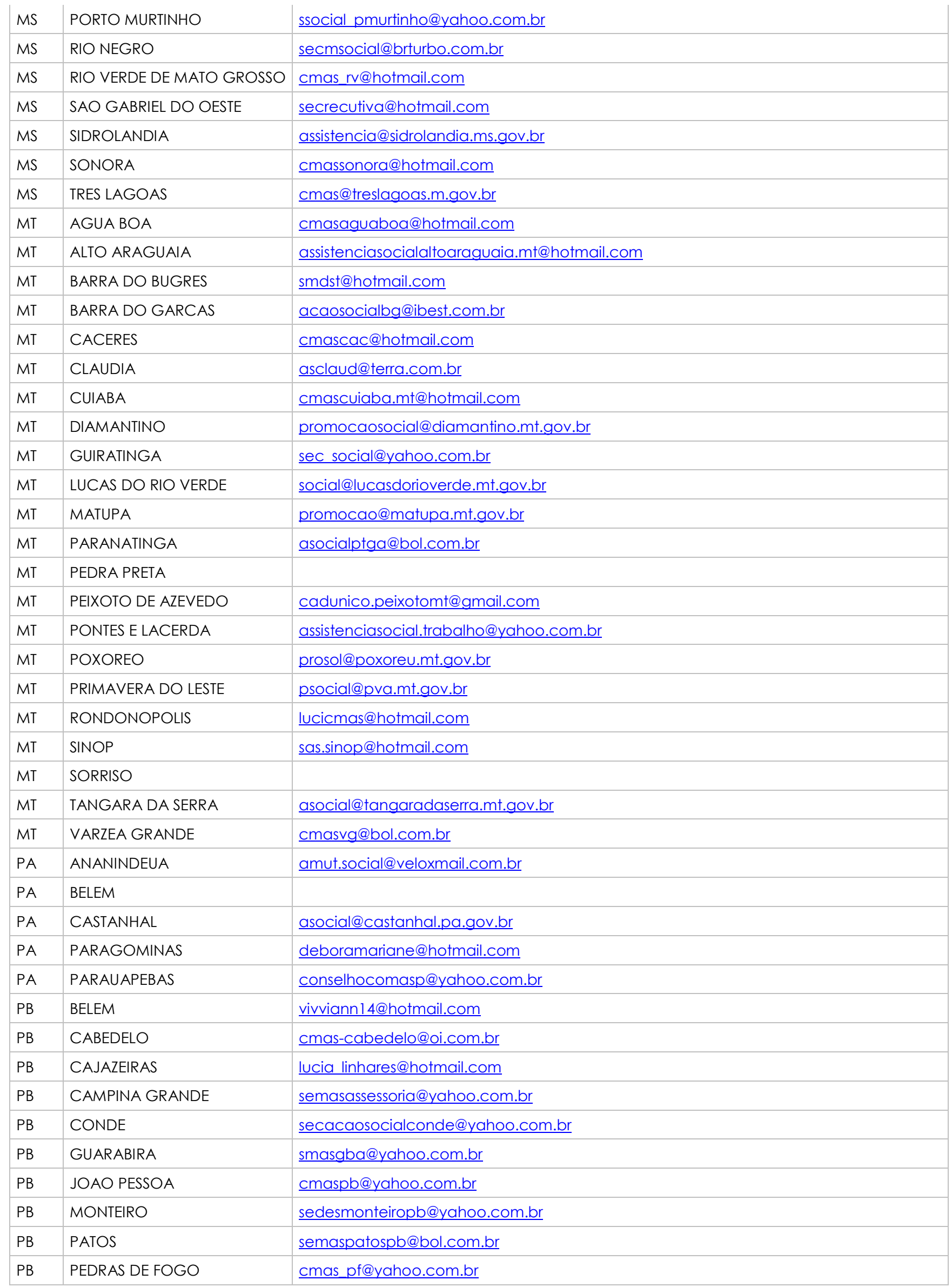




\begin{tabular}{|c|c|c|}
\hline PB & PIANCO & saspianco@yahoo.com.br \\
\hline PB & PICUI & pmspas@vol.com.br \\
\hline PB & POMBAL & \\
\hline PB & SOUSA & helder225@hotmail.com \\
\hline PE & GARANHUNS & assistenciasocial@garanhuns.pe.gov.br \\
\hline PE & $\begin{array}{l}\text { JABOATAO DOS } \\
\text { GUARARAPES }\end{array}$ & \\
\hline PE & PETROLINA & casadosconselhos-petrolina@hotmail.com \\
\hline PE & RECIFE & kmagda@recife.pe.gov.br \\
\hline PE & SALGUEIRO & acaosocial@salgueiro.pe.gov.br \\
\hline $\mathrm{Pl}$ & TERESINA & semtcas@gmail.com \\
\hline PR & ALTO PARANA & altoparana_social@yahoo.com.br \\
\hline PR & ARAPONGAS & semas@arapongas.pr.gov.br \\
\hline PR & ASSAI & agathe@vol.com.br \\
\hline PR & ASTORGA & sec.executiva.social@astorga.pr.gov.br \\
\hline PR & CAMBE & acaosocial@cambe.pr.gov.br \\
\hline PR & CAMPO MOURAO & \\
\hline PR & CASCAVEL & seaso2@cascavel.pr.gov.br \\
\hline PR & COLORADO & assistsocial@colorado.pr.gov.br \\
\hline PR & CORNELIO PROCOPIO & acaosocial@cp.pr.gov.br \\
\hline PR & CRUZEIRO DO SUL & elidesimo@hotmail.com \\
\hline PR & CURITIBA & conselhos@fas.curitiba.pr.gov.br \\
\hline PR & DOIS VIZINHOS & acaosocial@doisvizinhos.pr.gov.br \\
\hline PR & FOZ DO IGUACU & conselho.cmas@fozdoiguacu.pr.gov.br \\
\hline PR & GOIOERE & semasgre@gmail.com \\
\hline$P R$ & IBIPORA & assistenciasocial@ibipora.pr.gov.br \\
\hline PR & INAJA & mimiinaja@bol.com.br \\
\hline PR & IPORA & assistipora@yahoo.com.br \\
\hline PR & JARDIM OLINDA & \\
\hline PR & LOANDA & cras.loanda@hotmail.com \\
\hline$P R$ & LONDRINA & cmas@londrina.pr.gov.br \\
\hline PR & MARINGA & comas@maringa.pr.gov.br \\
\hline PR & NOVA ESPERANCA & joventinosouza@msn.com \\
\hline PR & NOVA LONDRINA & secretariadebemestarsocial@yahoo.com.br \\
\hline PR & PARANACITY & social@paranacity.pr.gov.br \\
\hline PR & PARANAPOEMA & craspoema@hotmail.com \\
\hline PR & PARANAVAI & cmas_pvai@hotmail.com \\
\hline PR & PIRAQUARA & castorinan@pop.com.br \\
\hline PR & PONTA GROSSA & cmaspg@bol.com.br \\
\hline PR & PORTO RICO & $\underline{\text { linda.paif@bol.com.br }}$ \\
\hline PR & ROLANDIA & \\
\hline PR & $\begin{array}{l}\text { SANTA CRUZ DE MONTE } \\
\text { CASTELO }\end{array}$ & $\underline{\text { socialscmc@netw.com.br }}$ \\
\hline PR & SANTA FE & assistenciasocial@kfnet.com.br \\
\hline PR & SANTA ISABEL DO IVAI & pmstaii@yahoo.com.br \\
\hline PR & SANTA MONICA & \\
\hline
\end{tabular}




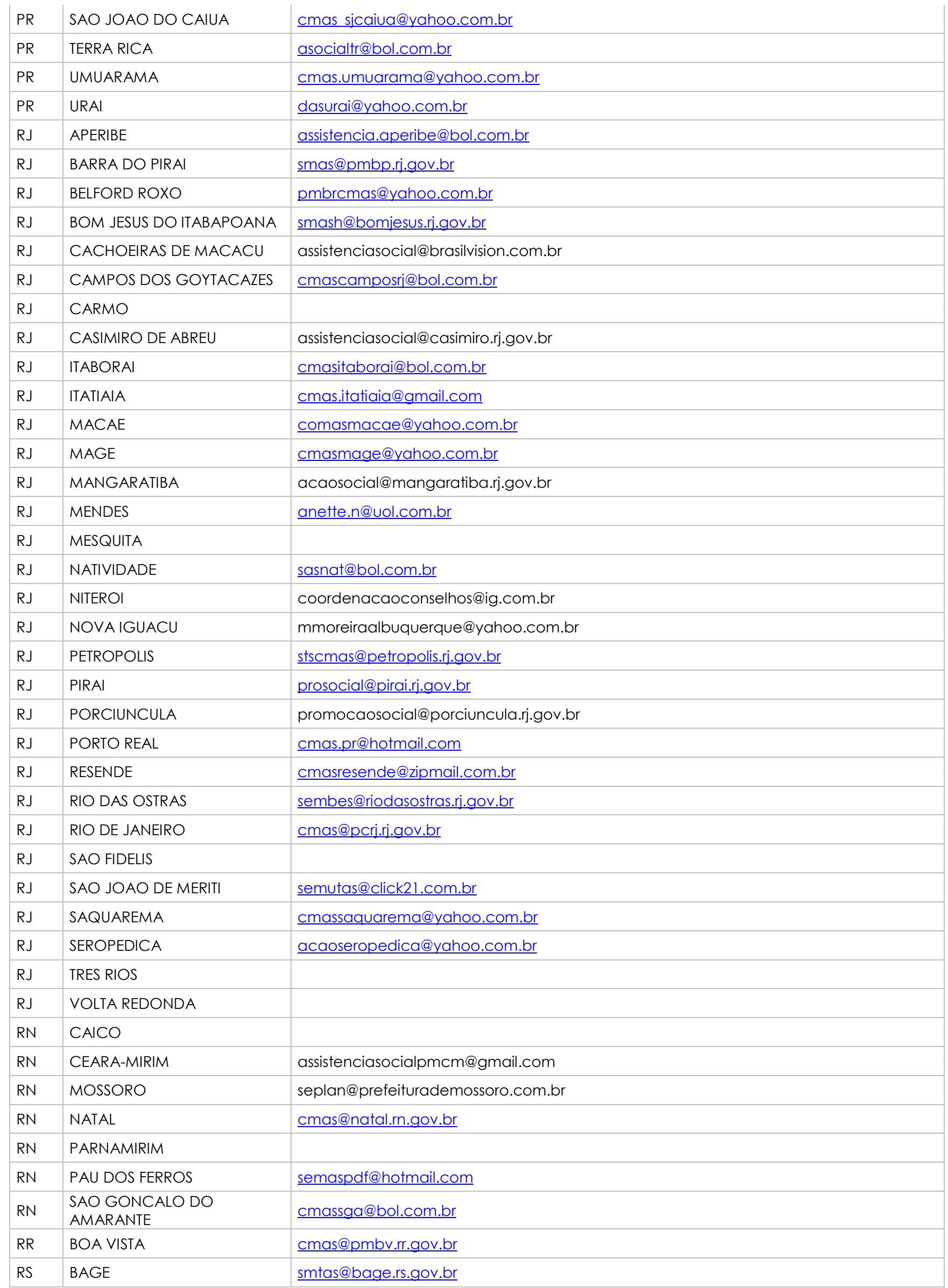




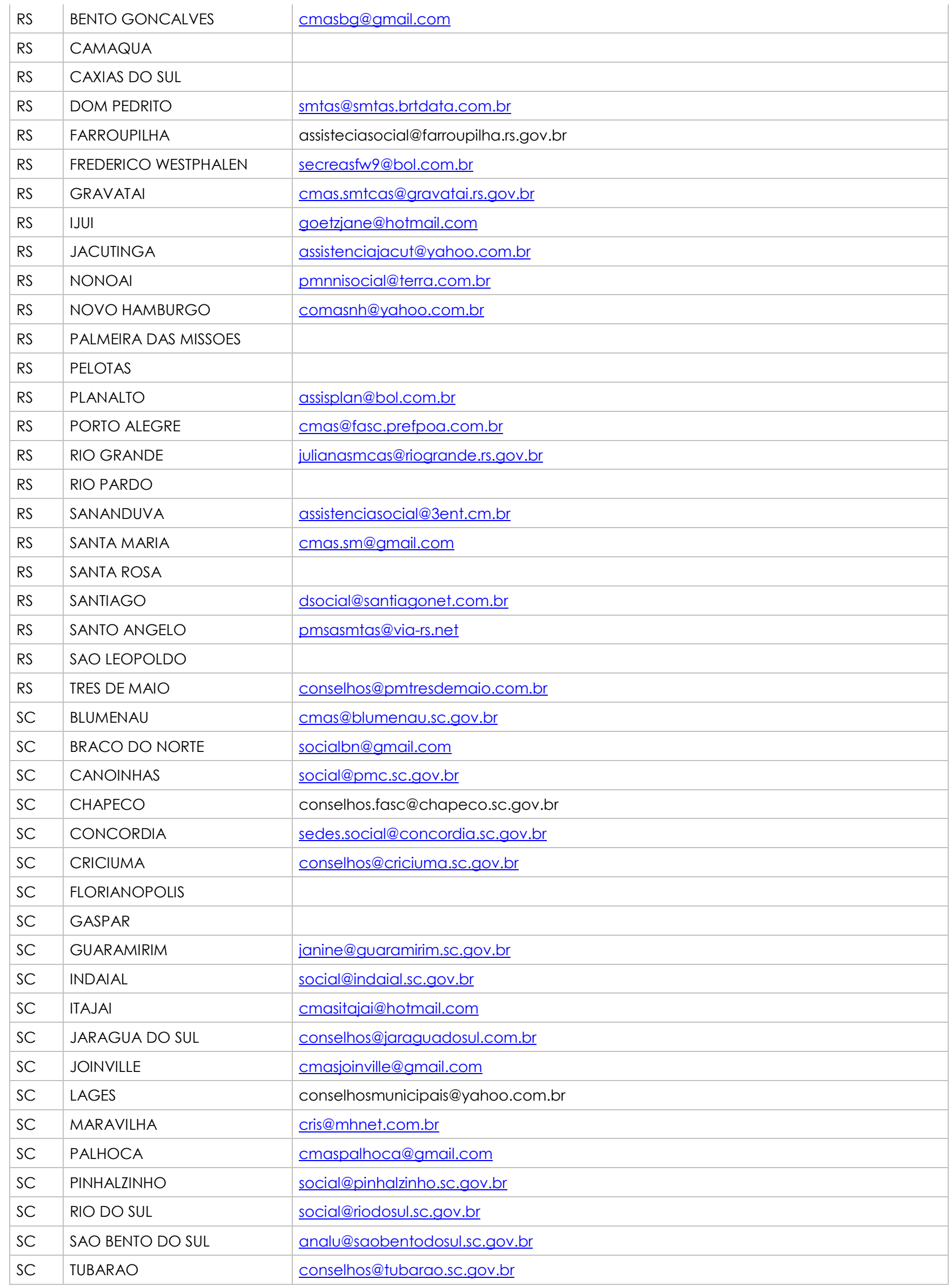




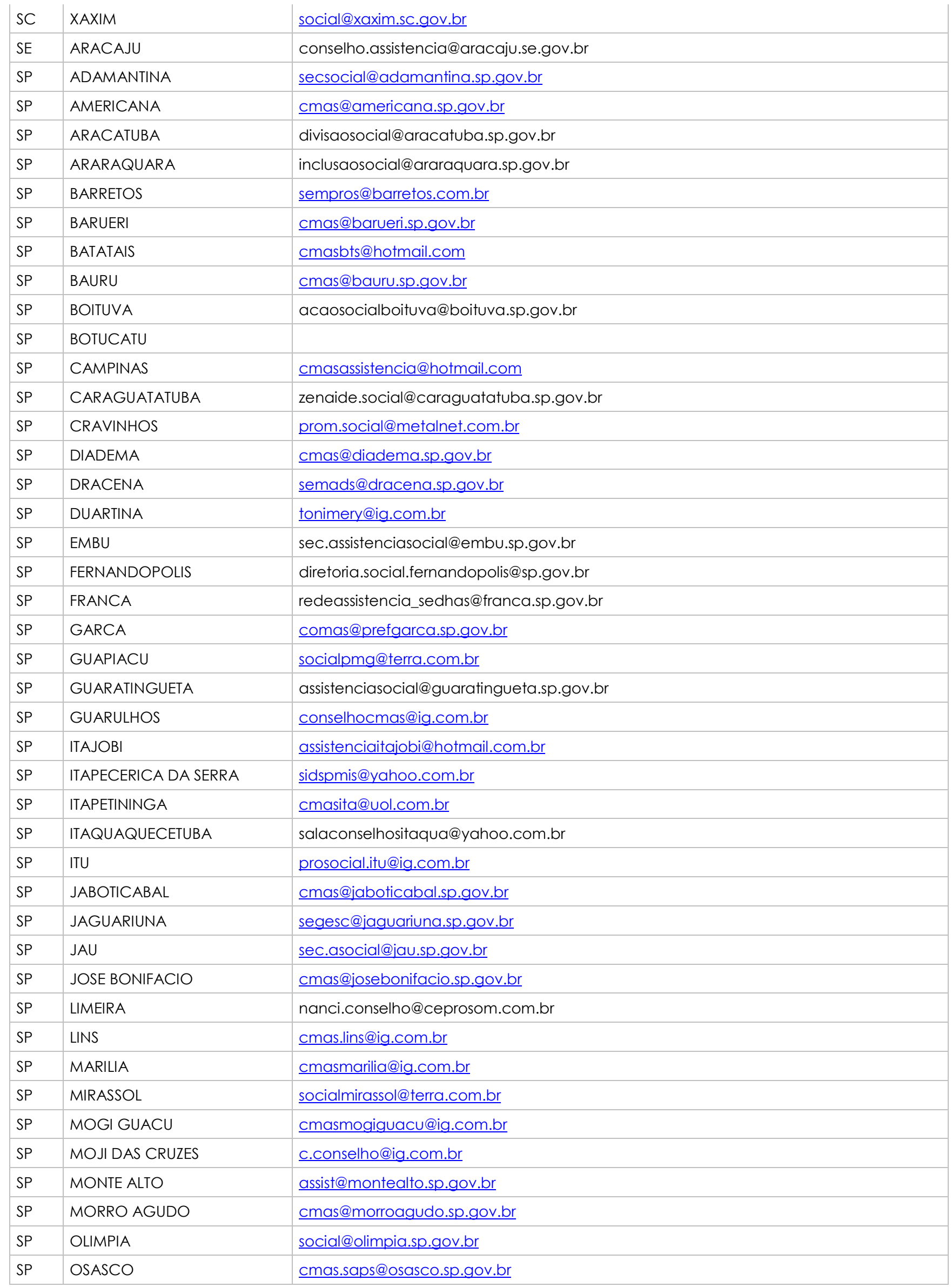




\begin{tabular}{|c|c|c|}
\hline SP & OURINHOS & cmas.ourinhos@ig.com.br \\
\hline SP & PARAGUACU PAULISTA & assistencia@eparaguacu.sp.gov.br \\
\hline SP & PAULO DE FARIA & cmaspf@hotmail.com \\
\hline SP & PEDERNEIRAS & cmas@pederneiras.sp.gov.br \\
\hline SP & PIRAJUI & assistenciasocialpirajui@hotmail.com \\
\hline SP & PIRASSUNUNGA & comas@lancernet.com.br \\
\hline SP & PIRATININGA & cmaspiratininga@hotmail.com \\
\hline SP & POA & p.s.poa@ibest.com.br \\
\hline SP & PROMISSAO & esdras_cmp@hotmail.com \\
\hline SP & RIBEIRAO PRETO & cmas@semas.pmrp.com.br \\
\hline SP & RIO CLARO & cmasrc@prefeiturarc.sp.gov.br \\
\hline SP & SANTO ANDRE & cmas@santoandre.sp.gov.br \\
\hline SP & SANTO ANTONIO DE POSSE & promocaosocial@pmsaposse.sp.gov.br \\
\hline SP & SANTO ANTONIO DO PINHAL & social.pinhal@vol.com.br \\
\hline SP & SANTOS & casadosconselhos_seacon@yahoo.com.br \\
\hline SP & SAO BERNARDO DO CAMPO & cmassbc@yahoo.com.br \\
\hline SP & SAO CARLOS & \\
\hline SP & SAO JOSE DO RIO PRETO & cmasriopreto@empro.com.br \\
\hline SP & SAO JOSE DOS CAMPOS & \\
\hline SP & SAO PAULO & comassp@prefeitura.sp.gov.br \\
\hline SP & SAO ROQUE & cmas@saoroque.sp.gov.br \\
\hline SP & SERTAOZINHO & secretariadedesenvolvimentosocial@sertaozinho.sp.gov.br \\
\hline SP & SEVERINIA & sempros@terra.com.br \\
\hline SP & SUMARE & \\
\hline SP & SUZANO & eqtecnica@ig.com.br \\
\hline SP & TABOAO DA SERRA & $\underline{\text { semuasc@terra.com.br }}$ \\
\hline SP & TANABI & assistenciasocial@tanabi.sp.gov.br \\
\hline SP & TAQUARITUBA & pmtaquaritubasocial@itelefonica.com.br \\
\hline SP & TUPA & comas@tupa.sp.gov.br \\
\hline SP & VOTUPORANGA & cmasvotuporanga@gmail.com \\
\hline $\mathrm{TO}$ & PALMAS & \\
\hline
\end{tabular}

\section{4- Instrumento de Pesquisa para coleta de dados junto aos conselheiros com termo de consentimento livre e esclarecido.}

Questionário de Pesquisa

Perfil de Uso das Novas Tecnologias de Informação e Comunicação pelos Conselheiros Municipais da Assistência Social 
Termo de Consentimento Livre e Esclarecido (TCLE)

Esta pesquisa visa contribuir para a reflexão sobre as relações do trabalho dos Conselhos Municipais para a gestão descentralizada da assistência social, observando o uso das Novas Tecnologias de Informação e Comunicação (NTIC's) e do SUASWeb, no que tange ao Plano de Ação do município e dos respectivos pareceres emitidos pelos conselheiros.

Dessa forma, contamos com sua participação, por sua livre e espontânea vontade, para identificar o perfil informacional da rede municipal dos Conselhos de Assistência Social. A pesquisa faz parte do trabalho de conclusão de curso de Bacharelado em Serviço Social da Universidade de Brasília (UnB), desenvolvido pelo estudante Eduardo Augusto Rodrigues Barros, com orientação do professor Perci Coelho de Souza e colaboração da professora Maria de Fátima Ramos Brandão do Departamento de Ciência da Computação.

A pesquisa tem finalidade exclusivamente acadêmica e os questionários poderão ser arquivados após a finalização do estudo. O sigilo dos dados pessoais da pesquisa será garantido e a participação está livre de qualquer remuneração ou despesa. A pessoa entrevistada poderá recusar responder qualquer das perguntas formuladas como também poderá não participar da pesquisa. Caso esteja de acordo com os termos de participação, peço cordialmente que os questionários sejam respondidos e em tempo hábil para sua análise e finalização do Trabalho de Conclusão de Curso no prazo de junho de 2009.

\title{
Instruções de preenchimento
}

Prezado Conselheiro,

Este questionário esta divido em cinco quadros de informações. No quadro 1 estão agrupadas as informações referentes ao conselho que vossa senhoria participa. No quadro 2 estão agrupadas as informações referentes ao perfil dos conselheiros. Esses dois quadros devem ser respondidos naturalmente, marcando as opções que julgar pertinente. Nos quadros 3, 4 e 5 estão agrupadas informações referentes a pesquisa de opinião dos conselheiros a respeito de diversas questões conforme orientações a seguir.

Nos quadros de 3 a 5 são listadas sentenças que representam práticas ou comportamentos de uso do das NTICs e do SUASWeb no processo de trabalho e gestão da informação pelos Conselhos de Assistência Social. Você deverá julgar cada sentença, com base na escala de opinião ou de freqüência fornecida, marcando um $\mathrm{X}$ na coluna que mais se aproxime à sua realidade. Considere a referência de tempo do último mês, se necessário. Observe os dois exemplos a seguir.

\author{
Exemplo 1 : \\ Utilizo a Internet \\ (1) Nunca (2) Poucas vezes (3) Várias vezes (4) Sempre
}

Você deverá marcar:

1 , caso você nunca tenha utilizado a internet; 


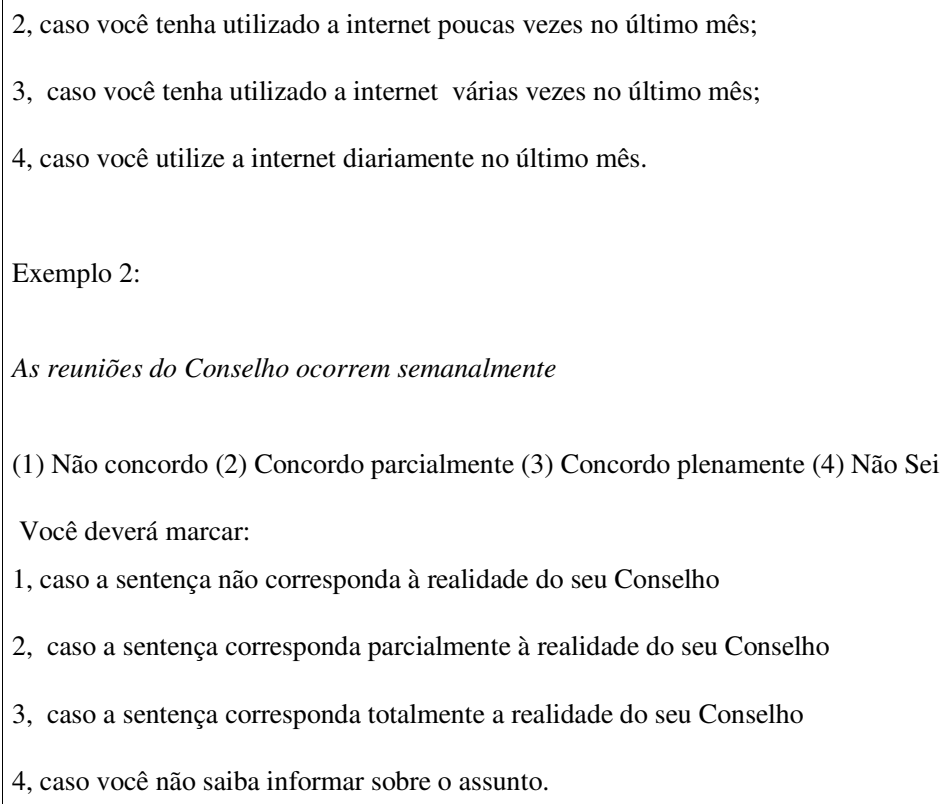

Quadro 1 - Identificação do Conselho Municipal/Distrital de Assistência Social

3. Município:

4. Estado: 5. UF:

Quadro 2 - Perfil do Conselheiro

6. Tomei posse neste Conselho:

( ) antes de 2007 （） em $2007 \quad$ ） Depois de 2007

7. Represento no Conselho o segmento:

( ) Governamental

( ) Soc.Civil (Usuário)

( ) Soc.Civil (trabalhador do setor)

( ) Soc.Civil )(entidade ou organização de Assistência Social)

( ) Outro especifique:

8. A minha base de representação no Conselho é:

( ) Secretaria de Assistência Social

( ) Beneficiário Benefício de Prestação Continuada (BPC)

( ) Beneficiário do Programa Bolsa Família (PBF)

( ) Beneficiário do CRAS

( ) Trabalhadores do setor 
( ) Outro especifique:

9. Sou um leitor na Internet de:

( ) Jornais

( ) Revistas

( ) Artigos Científicos

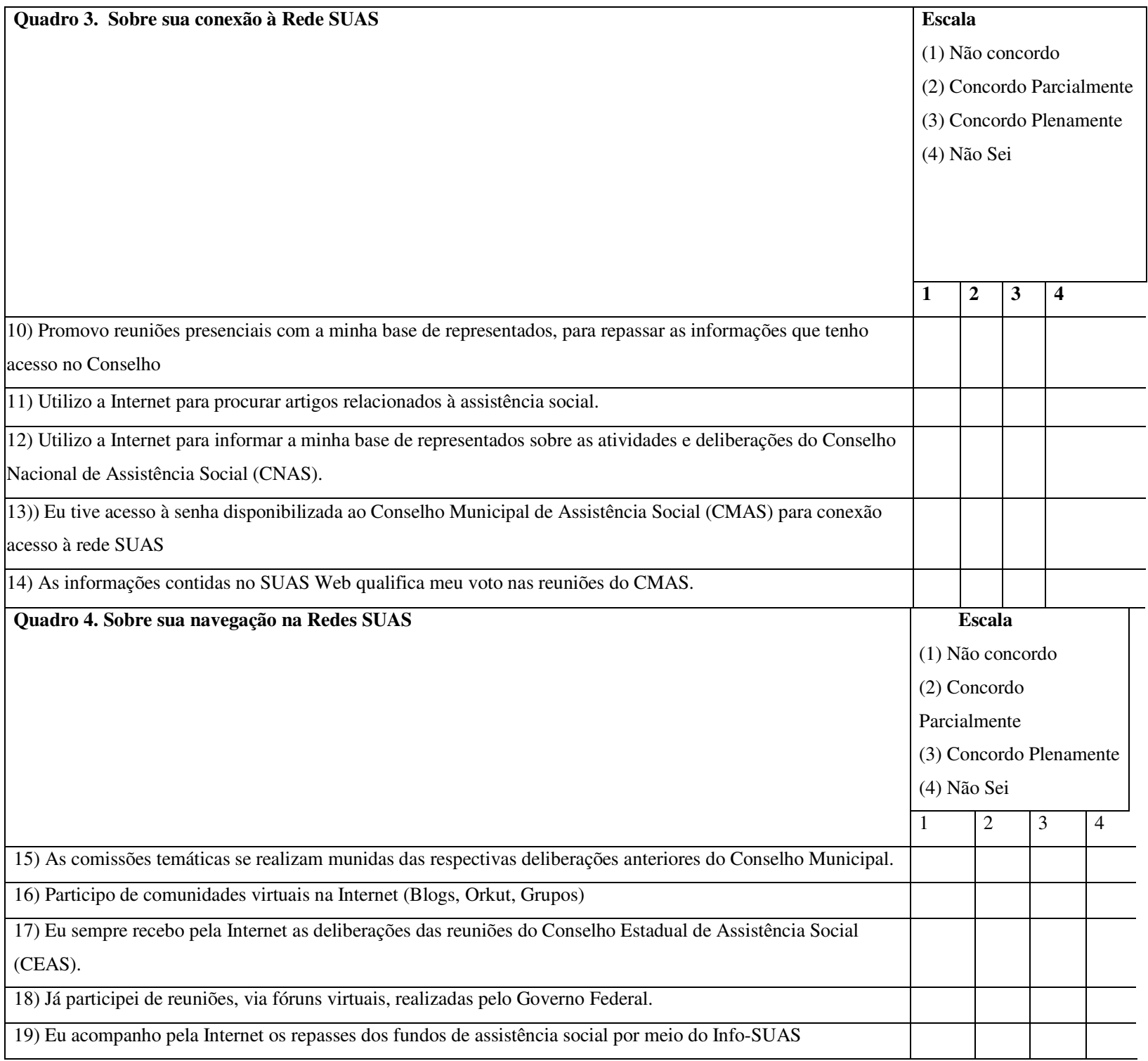




\begin{tabular}{|c|c|c|c|c|}
\hline \multirow[t]{2}{*}{ Quadro 5. Sua orientação política na Rede SUAS } & \multicolumn{4}{|c|}{$\begin{array}{l}\text { Escala } \\
\text { (1) Não concordo } \\
\text { (2) Concordo Parcialmente } \\
\text { (3) Concordo Plenamente } \\
\text { (4) Não Sei }\end{array}$} \\
\hline & 1 & 2 & 3 & 4 \\
\hline \multicolumn{5}{|l|}{ 20) Eu já participei da elaboração das pautas de um Fórum Regional de Assistência Social } \\
\hline \multicolumn{5}{|l|}{ 21) Já participei de salas de bate-papo na Internet com representantes do órgão do gestor Estadual } \\
\hline \multicolumn{5}{|l|}{ 22) Já acompanhei, via internet, atos da mesa diretora do Conselho Municipal usando a Internet } \\
\hline \multicolumn{5}{|l|}{$\begin{array}{l}\text { 23) A Rede Suas é um recurso que potencializa minha participação nas conferências de Assistência Social } \\
\text { (municipal, estadual, federal). }\end{array}$} \\
\hline $\begin{array}{l}\text { 24) Já me fundamentei, com base nos dados geo-referenciados, extraídos pelo Geo-SUAS para influenciar o voto } \\
\text { dos meus colegas de conselho }\end{array}$ & & & & \\
\hline
\end{tabular}

